$$
\text { M96050427 }
$$

\title{
Hanford Cultural Resources Laboratory Annual Report for Fiscal Year 1994
}
P. R. Nickens
M. K. Wright
N. A. Cadoret
M. V. Dawson
D. W. Harvey
E. M. Simpson

RECEIVT

SEP 20 lywi

OSTi

September 1995

Prepared for

the U.S. Department of Energy

under Contract DE-AC06-76RLO $1830^{\circ}$

Pacific Northwest National Laboratory

Richland, Washington 99352

\%attelle

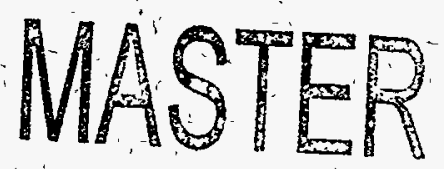




\section{DISCLAIMER}

This report was prepared as an account of work sponsored by an agency of the United Stàtes Government, Neither the United Statés Government'nor any agency. theréof, nor Battelle. Memorial Institute, nor any of their employees, makes any ivarranty, express or implied, or așsumes any legal liability or responsibility for the accuracy, completeness, or uséfulness of any information, apparatus, product, or process disclosed, or represents that its use would not infringe privately owned rights. Reference herein to any specific commercial product, process, or service by tráde name, trademark, manufacturer, or othérwise doès not necessarily, constitute or -imply its endorsement, recommendation, or favoring by the United States Government or any agency thereof, or Battelle Memorial Institute. The views and "opinions of authors expressed herein do not necessárily state or reflect thosè of the United States Government or any agency thereof.

\section{'PACIFIC NORTHWEST NATIONAL LABORATORY: operated by \\ BATTEELLE \\ for the}

UNITED STATES DEPARTMENT OF ENERGY under Contract $D E-A C O 6-76 R L O 1830$

Printed in the United States of America

Available to DOE and DOE contractors fróm the Office of Scientific and Technical Information, P.O. Box 62, OakRidge, TN 37831; prices available from (615) $576-8401$

Available to the public from the National Technical Information Service, U.S. Department óf Commerce, 5285 Port Royal Rd., Springfield, VA 22161

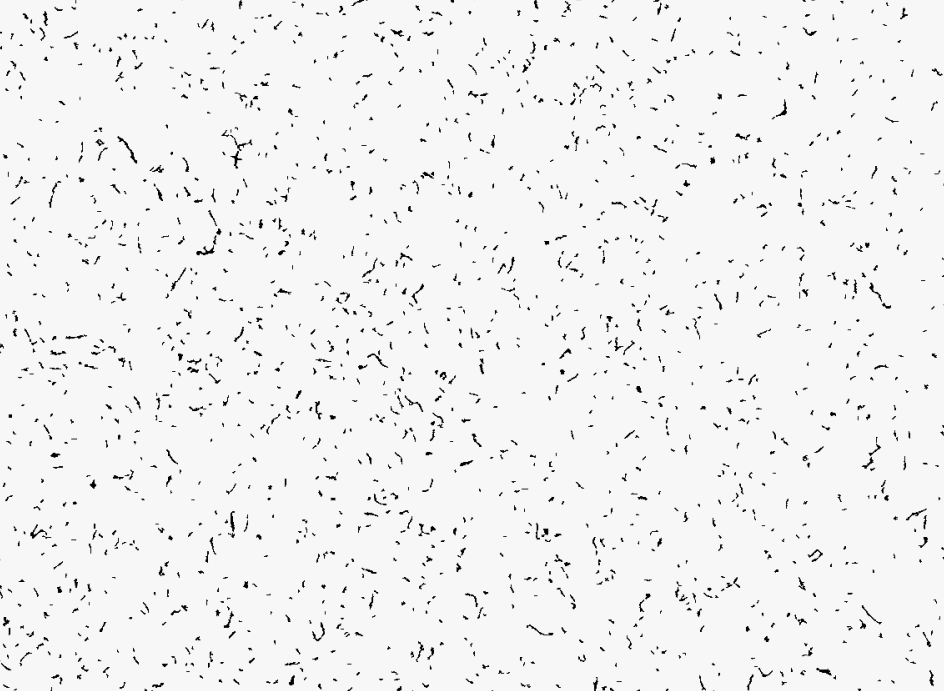




\section{HANFORD Cultural RESOURCES LABORATORY}

\section{Annual Report For Fiscal Year 1994}

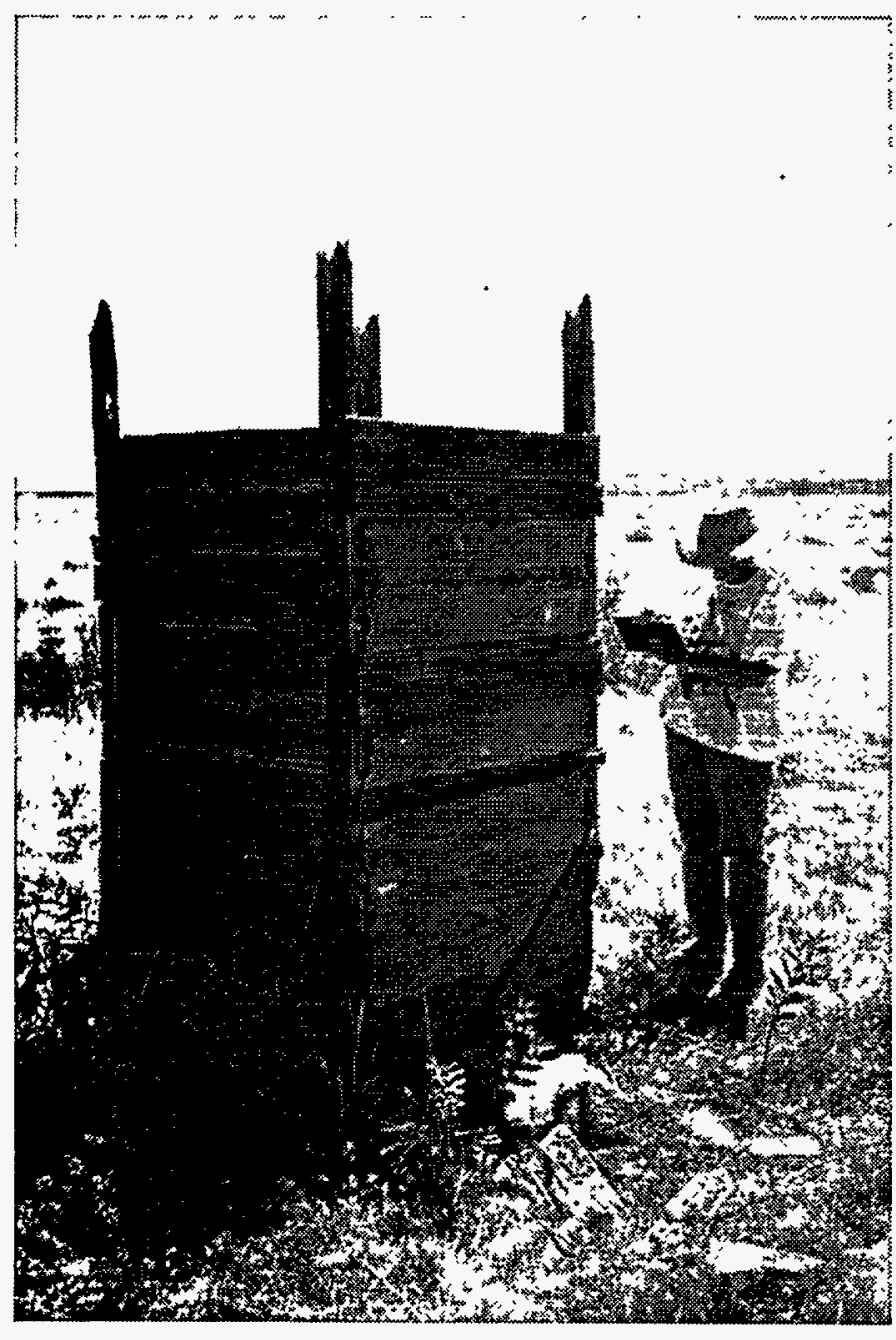

P. R. Nickens

M. K. Wright

N. A. Cadoret

M. V. Dawson

D. W. Harvey

E. M. Simpson

September 1995

Prepared for

the U.S. Department of Energy

under Contract DE-AC06-76RLO 1830

Pacific Northwest National Laboratory

Richland, Washington 99352 



\section{DISCLAIMER}

Portions of this document may be illegible in electronic image products. Images are produced from the best available original document. 


\section{Executive Summary}

The U.S. Department of Energy's (DOE) Hanford Site occupies 560 square miles of land along the Columbia River in southeastern Washington. For half a century, most of the area has been off limits to public use. As a result of isolation from human disturbances, the area still contains important Native American cultural resources as well as archaeological and historical resources that have been lost elsewhere in the region.

The Hanford Reach of the Columbia is considered to be one of the most archaeologically rich areas in the western Columbia Plateau. Native American descendants of various tribal affiliations who first populated the Reach in prehistoric and early historic times still use native plant and animal resources from the Hanford Site. Prehistoric archaeological sites common to the Hanford Site include remains of pit house villages, various types of open campsites, cemeteries, rock cairns, and hunting camps. Historical archaeological resources that reflect the more recent pre-Hanford history are scattered over the entire Site, including gold mine tailings along riverbanks of the Columbia and the remains of homesteads, agricultural fields, ranches, and irrigation-related features. Historic architectural resources from the Manhattan Project and Cold War eras include buildings and structures found primarily in the 100,200 , and 300 areas. The most important of these are the defense reactors and plutonium-production and processing facilities.

Federal laws require government agencies, including DOE, to protect and preserve these resources. The laws include the National Historic Preservation Act of 1966 (NHPA), the Archaeological Resources Protection Act of 1979. (ARPA), and the Native American Grave Protection and Repatriation Act of 1990 (NAGPRA). The American Indian Religious Freedom Act of 1978 (AIRFA) also requires that $D O E$ consider potential project impacts on $\mathrm{Na}$ - tive Americans' ability to believe, express, and exercise their traditional religions.

To manage the Hanford Site's archaeological, historical, and cultural resources, DOE's Richland Operations Office (RL) established the Hanford Cultural Resources Laboratory (HCRL) in 1987 as part of $\mathrm{Pa}$ cific Northwest National Laboratory. The HCRL ensures DOE complies with federal statutes, regulations, and guidelines through the Hanford Cultural Resources Management Plan (HCRMP), currently under revision. This plan guides all activities at $H a n f o r d$ that may affect historic sites or cultural artifacts.

In FY 1994, as part of priority tasks outlined in the management plan, HCRL staff 1 ) conducted cultural resource reviews pursuant to Section 106 of the NHPA, 2) conducted programs to identify, evaluate, and monitor historic and archaeological sites as specified in Section 110 of the NHPA and related regulations, 3 ) developed cultural resource protection and curation programs and public and government agency education pursuant to ARPA, and 4) provided DOERL with relevant information on cultural resources issues for federal, state, and tribal agencies.

Under the management plan, in compliance with Section 106 of the NHPA, cultural resource reviews are required before Hanford Site projects that entail disturbing ground and/or altering or demolishing existing structures are begun. The purpose of the review is to determine if proposed projects may impact any cultural property that is listed in or eligible for listing in the National Register of Historic Places (National Register). During FY 19.94, HCRL staff conducted 511 reviews, 29 of which required archaeological surveys and 10 of which required building documentation. FY 1994 surveys also included one project initiated in the previous year. Surveys covered approximately $11.35 \mathrm{~km}$. During the surveys, HCRL staff discovered six prehistoric archaeological 
sites, 23 historic archaeological sites, one paleontological site, and two archaeological sites with historic and prehistoric components. The cultural affiliation of three archaeological sites was not determined. Mitigative actions were taken to avoid any potential impact to sites listed or considered eligible for listing in the National Register.

In addition to monitoring activities conducted as part of Section 110 of the NHPA, HCRL staff conducted a 1-day river trip of the Hanford Reach accompanied by personnel from the Richland Operations Office and members of the Wanapum Tribe. Several archaeological sites along the river shore and on islands were visited to inspect present condition and effects of impacts resulting from both natural erosion and human intrusion.

In FY 1994, HCRL staff provided an inventory of the Laboratory's collections to the Richland Operations Office. Currently, there are 645 cultural resource sites and isolated finds recorded in HCRL's files. Forty-eight archaeological sites and one building are included in the National Register: one reactor building, three single arcaheological sites, and 45 in seven archaeological districts (Table S.1). This information was used by DOE to prepare a summary report of holdings for the Secretary of the Interior and affected Indian Tribes, as required by NAGPRA.

Table S.1 Historic Properties on the Hanford Site listed in the National Register and the Archaeological Sites Within Them

Property Name

Hanford Island Archaeological Site Hanford North A.D. (o) Locke Island A.D.

Paris Archaeological Site Rattlesnake Springs Sites Rygrass A.D.

Savage island A.D.

Snively Canyon A.D. Wooded Island A.D. 105-B Reactor

(a) Archaeological district.

(b) $\mathrm{N} / \mathrm{A}=$ not applicable.
Site(s) Included

45BN121

45BN124 through 45BN134, 45BN178

$45 \mathrm{BN} 137$ through $45 \mathrm{BN} 140,45 \mathrm{BN} 176$

45GR302a，45GR302b, 45GR302c,

45GR303 through 45GR305

45GR317

$45 \mathrm{BN} 170$ and $45 \mathrm{BN} 171$

$45 \mathrm{BN} 149$ through $45 \mathrm{BN} 151$

$45 B N 116$ through $45 B N 119$,

45FR257 through 45FR262

$45 \mathrm{BN} 172$ and $45 \mathrm{BN} 173$

45BN107 through 45BN112

$N / A^{(b)}$ 
Also in FY 1994, the discovery of human remains at the proposed construction site of Pacific Northwest Laboratory's Environmental Molecular Sciences Laboratory (EMSL) resulted in a major NAGPRA issue. HCRL personnel conducted various studies associated with relocating EMSL to a new site.

A significant accomplishment during FY 1994 was the establishment of an automated cultural resources database. A database structure was designed to facilitate HCRL activities, which was placed into a relational database management system. All existing data for cultural resources reviews, projects, and site forms were entered into the system. Also in FY 1994, a curation room was established in the Sigma V building. Roll-out space saver shelving and a new security system were installed. The artifact collections were relocated to this room.

Education of the public, Hanford workers, and nonHanford professionals is a key part of the Cultural Resources Project. Public education activities in FY 1994 consisted of giving five presentations and participating in one interview for a newspaper article. Staff also developed a traveling display depicting Hanford Site history and resource protection needs. The display covers archaeology, Native American, pre-1943 Euroamerican, and Manhattan Project/Cold War eras. The display, partially developed in FY 1993, was reviewed for completeness and accuracy this fiscal year. 


\section{Photo Acknowledgments}

The photos in this report show historic features in the McGee Ranch/Cold Creek Valley district. Descriptions of specific photos, and the page on which they appear, follow. All photos are on file at the Hanford Cultural Resources Laboratory (HCRL).

Photo Description

Page Number

HCRL staff member recording a water diversion structure, part of an irrigation system in the Cold Creek Valley Title page .

Formerly elevated section of irrigation flume 1.1

Close-up of irrigation flume 1.3

Irrigation flume 1.4

Trademark from base of porcelain container (Image has been stylized)

Wire-wrapped wooden irrigation pipe 2.2 



\section{Acronyms}

AIRFA American Indian Religious Freedom Act

ARPA Archaeological Resources Protection Act

asl Above mean sea level

AWU Associated Western Universities

BN Benton County

CERCLA Comprehensive Environmental Response, Compensation and Liability Act

CFR Code of Federal Regulations

DOE-RL Department of Energy, Richland Field Office

EIS Environmental Impact Statement

EMSL Environmental Molecular Sciences Laboratory

ERDF Environmental Restoration Disposal Facility

GIS Geographic Information System -

HCRC\# Hanford Cultural Resources Case Number

HCRL Hanford Cultural Resources Laboratory

HCRMP Hanford Cultural Resources Management Plan

MPD Multiple Property Document

NAGPRA Native American Grave Protection and Repatriation Act

NHPA National Historic Preservation Act

PA Programmatic Agreement

RCRA Resource Conservation and Recovery Act of 1976

TCP Traditional Cultural Property

TRAC Teacher Research Associates Program

TWRS Tank Waste Remediation Systems

SNFSF Spent Nuclear Fuel Storage Facility 



\section{Contents}

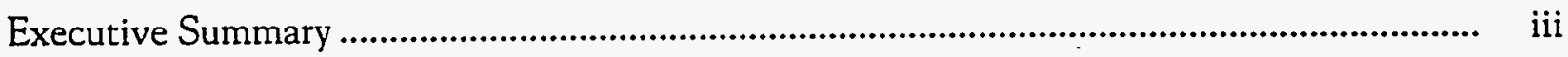

Photo Acknowledgments ....................................................................................................... vii

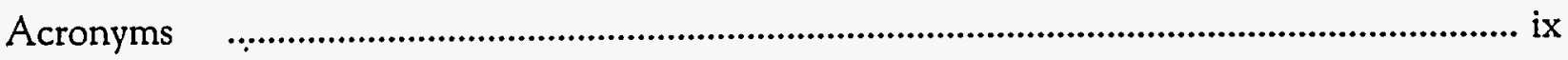

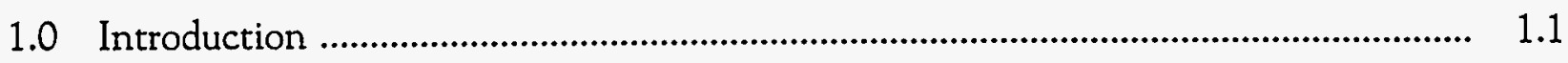

1.1 Background .................................................................................................... 1.1

1.1.1 Native American Cultural Resources ......................................................... 1.2

1.1.2 Archeological Resources .......................................................................... 1.2

1.1.3 'Historic Archeological Resources .............................................................. 1.3

1.1.4 Historic Architectural Resources ................................................................ 1.4

1.2 Hanford Cultural Resources Laboratory ................................................................ 1.4

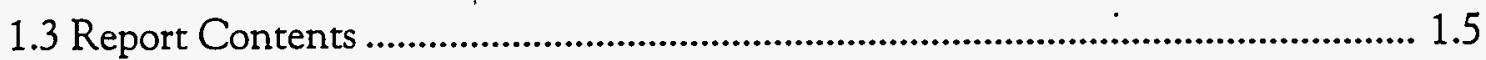

2.0 National Historic Preservation Act Section 106 Compliance Reviews ......................... 2.1

2.1 Reviews Conducted ................................................................................. 2.2

2.2 Cultural Resources Identified ............................................................................... 2.3

2.3 Large Survey Projects Completed in Fiscal Year 1994 ....................................... 2.3

2.3.1 Basalt Quarry Sites ................................................................................... 2.5

2.3.2 Tank Waste Remediation Systems Complex ………................................ 2.12

2.3.3 Environmental Molecular Sciences Laboratory .......................................... 2.16

2.3.4 Spent Nuclear Fuels Storage Facility ........................................................ 2.18

2.3.5 Environmental Restoration Disposal Facility ............................................ 2.22

3.0 National Historic Preservation Act Section 110 Compliance Reviews............................. 3.1

3.1 Determinations of Eligibility ........................................................................................ 3.1

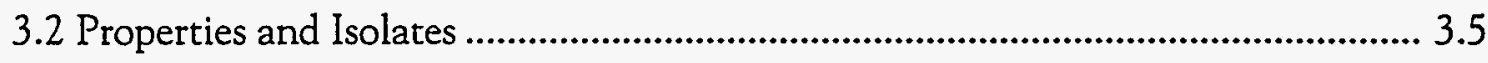

3.3 Programmatic Agreement .................................................................................. 3.5

4.0 A.rchaeological Resources Protection Act (ARPA) ......................................................... 4.1

5.0 American Indian Religious Freedom Act and Native American Grave Protection and Repatriation Act .......................................................................................... 5.1 


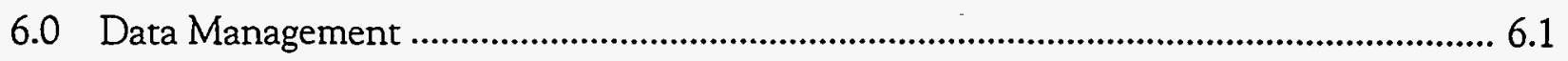

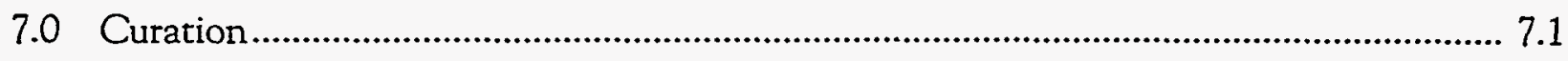

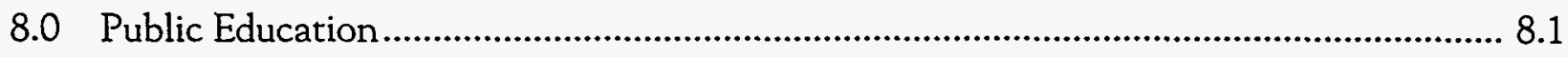

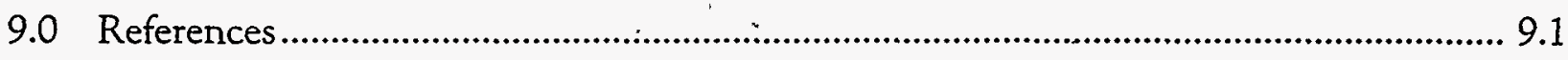

Appendix A - Section 106 Reviews Conducted in FY 1994 ..................................................... A.1

Appendix B - Surveys Completed in FY 1994 for Section 106 Reviews ..................................... B.1

Appendix C.- Buildings Documented in FY 1994 for Section 106 Reviews ............................. C.1

Appendix D - Archaeological Sites Identified in FY 1994 ....................................................... D. 1

Appendix E - Archaeological Isolates Identified in FY 1994 ..................................................... E.1 


\section{Figures}

2.1 Location of Large Survey Projects Completed in FY 1994 .............................................. 2.4

2.2 Proposed McGee Ranch Quarry ..................................................................................... 2.6

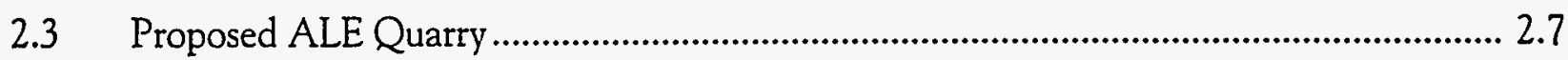

$2.4 \quad$ Proposed Gable Butte Quarry ........................................................................................ 2.8

2.5 Proposed Horn Rapids Quarry ................................................................................... 2.9

2.6 Proposed TWRS Site A ......................................................................................... 2.14

$2.7 \quad$ Proposed TWRS Site B ............................................................................................. 2.15

2.8 Area Surveyed for the EMSL, Site 6 …..................................................................... 2.17

2.9 Proposed SNFSF, HCRC \#94-600-001 ....................................................................... 2.20

2.10 Proposed SNFSF, HCRC \#94-600-017 ………....................................................... 2.21

\section{Tables}

S.1 Historic Properties on the Hanford Site Listed in the National Register ........................... iv of Historic Places and the Archaeological Sites Within Them

1.1 Historic Properties on the Hanford Site Listed in the National Register ....................... 1.1 of Historic Places and the Archaeological Sites Within Them

2.1 Sites and Isolates Recorded During Survey for the Proposed Basalt Quarries................. 2.10

3.1 Properties and Isolates Added to Hanford Site Database in FY 1994 ............................... 3.5

A.1 Section 106 Reviews Conducted in FY 1994 :............................................................... A.1

B.1 Surveys Completed in FY 1994 for Section 106 Reviews................................................ B.1

C.1 Buildings Documented in FY 1994 for Section 106 Reviews (Class VI) ........................ C.1

D.1 Archaeological Sites Identified in FY 1994 ............................................................ D.1

E.1 Archaeological Isolates Identified in FY 1994 ............................................................ E.1 



\subsection{Introduction}

\subsection{Background}

The U.S. Department of Energy's (DOE) Hanford Site occupies 560 square miles of land along the Columbia River in southeastern Washington. For more than 50 years, public access to the Site has been limited. As a result, many important Native American cultural resources as well as archaeological and historical resources have been largely undisturbed.

The Hanford Reach of the river is one of the most archaeologically rich areas in the western Columbia Plateau. It contains numerous well-preserved archaeological sites representing prehistoric, historic, and

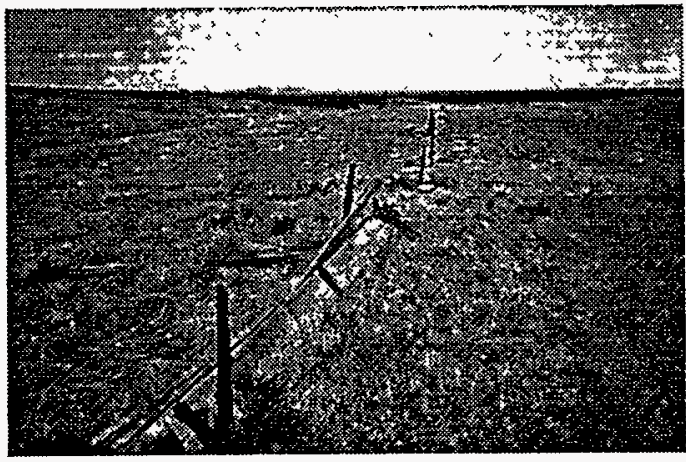

contact periods and is still thought of as a homeland by many Native American people. Historic period resources include sites, buildings, and structures from the preHanford Site, Manhattan Project, and Cold War eras.

Currently, there are $645 \mathrm{cul}$ tural resource sites and isolated finds recorded in the files of the Hanford Cultural Resources Laboratory (HCRL). Forty-eight archaeological sites and one bulding are included in the $\mathrm{Na}-$ tional Register of Historic Places: one reactor building, three single archaeological sites, and 45 in seven archaeological districts (Table 1.1).

Table 1.1 Historic Properties on the Hanford Site listed in the National Register and the Archaeological Sites Within Them

Property Name

Hanford Island Archaeological Site Hanford North A.D.(1) Locke Island A.D.

Paris Archaeological Site Rattlesnake Springs Sites

Rygrass A.D.

Savage Island A.D.

Snively Canyon A.D.

Wooded Island A.D.

105-B Reactor

(a) Archaeological district.

(b) $\mathrm{N} / \mathrm{A}=$ not applicable.
Site(s) Included

45BN121

45BN124 through 45BN134, 45BN178

45BN137 through 45BN140, 45BN176

45GR302a, 45GR302b, 45GR302c,

45GR303 through 45GR305

45GR317

$45 \mathrm{BN} 170$ and $45 \mathrm{BN} 171$

$45 B N 149$ through $45 B N 151$

$45 B N 116$ through $45 B N 119$,

45FR257 through 45FR262

$45 \mathrm{BN} 172$ and $45 \mathrm{BN} 173$

45BN107 through 45BN1 12

$N / A^{(b)}$ 
National Register nominations have been prepared for several archaeological districts and sites considered eligible for listing in the National Register. $\mathrm{Na}$ tional Register nominations for the Gable Mountain/ Gable Butte Cultural District, the Wahluke Archaeological District, and Coyote Rapids Archaeological District were submitted to the Washington State Historic Preservation Officer (SHPO) for review and

\subsubsection{Native American Cultural Resources}

In prehistoric and early historic times the Hanford Reach was populated by Native Americans of various tribal affiliations. The Wanaupum and Chamnapum band of the Yakama tribe dwelt along the Columbia River from south of Richland upstream to Vantage (Relander 1956; Spier 1936). Some descendants of the Wanapum Tribe still live nearby at Priest Rapids and others have been incorporated into the Yakama and Umatilla reservations. Palus people, who lived on the lower Snake River, joined the Wanapum and Chamnapum to fish the Hanford Reach of the Columbia River, and some inhabited the river's east bank (Relander 1956; Trafzer and Scheuerman 1986). Walla Walla and Umatilla people also made periodic visits to fish in the area. Descen-

\subsubsection{Archaeological Resources}

People have inhabited the Middle Columbia River region since the end of the glacial period. More than 10,000 years of prehistoric human activity in this largely arid environment have left extensive archaeological deposits along the river shores (Chatters 1989; Greeengo 1982; Leonhard and Rice 1970). Well-watered inland areas from the river also show evidence comment in the 1970s. None were approved for submittal to the Keeper of the National Register. The SHPO did, however, list each district in the State Register of Historic Places. All three districts are pending renomination to the National Register.

The section following briefly describes the various cultural resources of the Hanford Site.

dants of these people retain traditional secular and religious ties to the region, and many, have knowledge of the ceremonies and lifeways of their ancestral culture.

The Washani religion, which has ancient roots and had its start on the Hanford Site, is still practiced by many people on the Yakama, Umatilla, Warm Springs, and Nez Perce reservations. Native plant and animal foods, some of which can be found on the Hanford Site, are used in the ceremonies performed by tribal members. Tribes have expressed an interest in renewing their use of these resources, and DOE is assisting them in this effort.

of concentrated human activity (Chatters 1982, 1989; Daugherty 1952;: Greene 1975; Leonhardy and Rice 1970; Rice 1980), and recent surveys have indicated extensive, although dispersed, use of arid lowlands for hunting. Graves are common in various settings, and spirit quest monuments are still found on high, rocky summits of the mountains and buttes (Rice 
1968a). Throughout most of the region, hydroelectric development, agricultural activities, and domestic and industrial construction have destroyed or covered the majority of these deposits. Amateur artifact collectors have had an immeasurable impact on what remains. By virtue of their inclusion in the Hanford Site, from which the public is restricted, archaeological deposits found in the Hanford Reach of the Columbia River on adjacent plateaus and mountains have been spared some of the disturbances that have befallen other sites. The Hanford Site is thus a de facto reserve of archaeological information of the kind and quality that have been lost elsewhere in the region.
Two-hundred and eighty-three prehistoric sites have been found on the Hanford Site, 17 of which contain prehistoric and historic components. Prehistoric archaeological sites common to the Hanford Site include remains of pit house villages, various types of open campsites, cemeteries, rock cairns, hunting camps, game drive complexes, and quarries in mountains and rocky bluffs (Rice 1968a, 1968b, 1980), hunting/kill sites in lowland stabilized dunes, and small temporary camps near perennial sources of water located away from the river (Rice 1968b).

\subsubsection{Historic Archaeological Resources}

Lewis and Clark were the first Euroamericans who came to the Mid-Columbia region. They traveled along the Columbia and Snake rivers during their 1803 to 1806 exploration of the Louisiana Territory. They were followed by fur trappers, military units, and miners who passed through on their way to more productive lands up and down river passageways and across the Columbia Basin. It was not until the 1860 s that merchants set up stores, a freight depot, and the White Bluffs Ferry on the Hanford Reach. Chinese miners began to work the gravel bars for gold. Cattle ranches were established in the 1880s, and farmers soon followed. Several small, thriving towns, including Hanford, White Bluffs, and Ringold grew up along the riverbanks in the early twentieth century. Ferries were

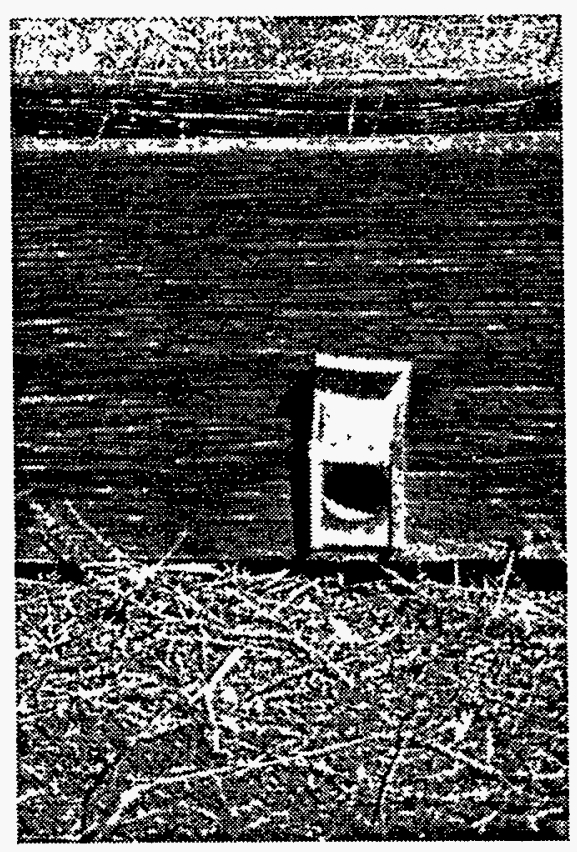

established at several locations, including Wahluke and Richmond. The towns and nearly all other structures were razed after the U.S. government acquired the land for the Hanford Engineer Works in 1943 (Chatters 1989; ERTEC 1981; Rice 1980).

A total of 201 historic archaeological sites and numerous historic properties have been recorded, which are associated with the pre-Hanford Site era. Properties from the preHanford Site era include semi-subterranean structures near McGee Ranch; the Hanford Irrigation and Power Company's pumping plant at Coyote Rapids; the Hanford Irrigation Ditch; the Hanford townsite, pumping plant and high school; Wahluke Ferry; the White Bluffs townsite and bank; the Richmond Ferry; Arrowsmith townsite; a cabin at East 
White Bluffs Ferry landing; the White Bluffs road; the Chicago, Milwaukee, St. Paul, and Pacific Railroad (Priest Rapids-Hanford Line) and associated whistle stops; and Bruggeman's fruit warehouse (Rice 1980).

The HCRL has recorded historic archaeological sites, including an assortment of farmsteads, corrals, and dumps since 1987. ERTEC Northwest was responsible for minor test excavations at some historic sites, including the Hanford townsite. Resources from the pre-Hanford Site period are scattered over the entire Hanford Site and include numerous areas of gold mine tailings along riverbanks of the Columbia and the remains. of homesteads, agricultural fields, ranches, and irrigation-related features.

\subsubsection{Historic Architectural Resources}

Historic architectural resources documented from the Manhattan Project and Cold War eras inclúde buildings and structures primarily found in the 100,200 , and 300 Areas. The most important of these are the defense reactors and plutonium-production and processing facilities. The first reactors (105-B, 105-D, and 105-F) were constructed in 1943 as part of the Manhattan Project.
Plutonium for the first atomic explosion at the Trinity test site and the bomb that destroyed Nagasaki to end World War II were produced in the 105-B facility. Additional reactors and processing facilities were constructed after World War II during the Cold War period. All reactor containment buildings still stand, although many ancillary structures have been removed.

\subsection{Hanford Cultural Resources Laboratory}

Federal laws require government agencies, including DOE, to protect and preserve the resources described in Section 1.1. The laws include the $\mathrm{Na}$ tional Historic Preservation Act of 1966 (NHPA), the Archaeological Resources Protection Act of 1979 (ARPA), and the Native American Grave Protection and Re-

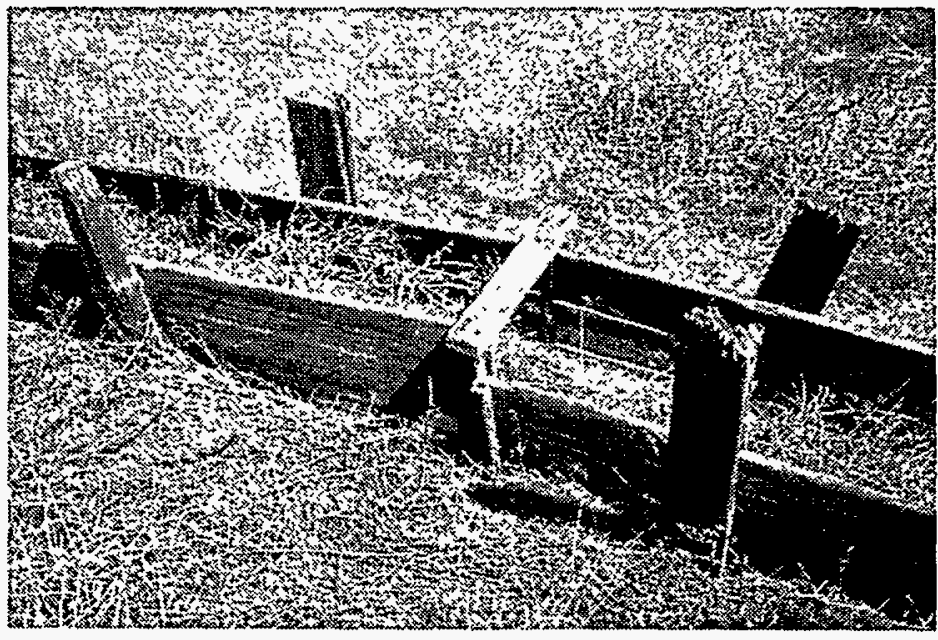
patriation Act of 1990 (NAGPRA). The American Indian Religious Freedom Act of 1978 (AIRFA) also requires that DOE consider potential project impacts on $\mathrm{Na}$ tive Americans' ability to believe, express, and exercise their traditional religions.

To manage the Hanford Site's archaeological, historical, and cultural resources, DOE's Richland Field Office estab. lished the Hanford Cultural Resources Laboratory (HCRL) in 1987 as part of Pacific Northwest National Laboratory. The 
HCRL ensures DOE complies with federal statutes, regulations, and guidelines through the Hanford Cultural Resources Management Plan (HCRMP). This plan guides all activities at Hanford that may affect historic sites or cultural artifacts.

Under the management plan in FY 1994, the HCRL completed the following tasks in order of priority:

- conducted cultural resource reviews pursuant to Section 106 of the NHPA for all proposed surfacedisturbing or major renovation/demolition projects to assess their potential impact on cultural resources

- conducted programs to identify, evaluate, and monitor cultural resources as specified in Section 110 of the NHPA and related regulations and guidelines

- developed cultural resource protection and curation programs and conducted public education pursuant to ARPA

- assembled an inventory of archaeological collections from the Hanford Site, pursuant to NAGPRA, and provided the Richland Operations Office with cultural resources information for federal, state, and tribal agencies, which included maintaining a cultural resource database and Geographic Information System (GIS) for the Hanford Site, drafting Programmatic Agreements, and updating the HCRMP.

\subsection{Report Contents}

This report describes the tasks outlined in section 1.2, in order of priority. Sections $2.0-8.0$ explain the tasks conducted, describe methods for performing the tasks, and summarize results. Appendices A -
E provide details on reviews and surveys conducted, buildings documented, and archaeological sites and isolates identified in FY 1994. 


\subsection{National Historic Preservation Act Section 106 Compliance Reviews}

In compliance with Section 106 of the NHPA, the HCRL conducts cultural resource reviews before Hanford Site projects that entail disturbing ground or building alteration/ demolition to existing structures are begun. About 100 to 120 reviews were conducted annually through 1991. This figure rose to more than 500 reviews during 1994. These reviews ensure that prehistoric and historic sites and existing structures eligible for the National Register are not adversely impacted by proposed projects.

A cultural resource review begins with a literature and records search of HCRL files. For excavation projects, if a proposed project area is found to be eligible, but cannot be avoided, mitigation

of project impacts is necessary. If no sites are found on the surface but the project area is known to be in a culturally sensitive location, cultural resource specialists may monitor the construction for subsurface archaeological materials. Projects could be halted until site mitigation has been completed if archaeological materials are discovered during construction activities. If human remains are inadvertently discovered during construction, all work must cease as required by the NAGRPA. If significant building alterations and demolitions are proposed, the building is recorded on a historic property inventory form, which includes a description of physical appearance, a statement of historical significance, and photographic documentation. Determinations of poten-

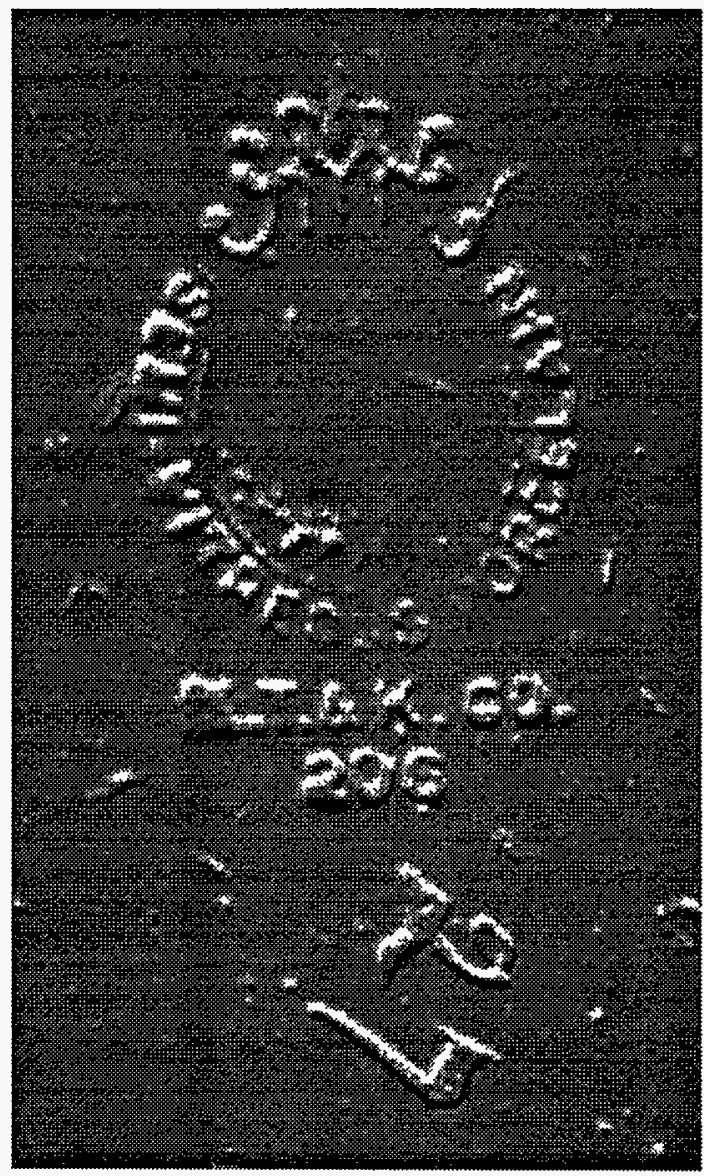

tial eligibility for cultural resource sites and buildings/ structures are submitted to the SHPO for concurrence. If the archaeological site, traditional cultural property, or building/ structure is found to be eligible, a more extensive method of documentation or data recovery must be used as a form of mitigation if adverse impacts cannot be avoided.

Cultural resource reviews are conducted in accordance with Section 3.1.1 of the HCRMP. These reviews are classified according to four criteria: 1) whether the project entails maintenance or new construction; 2) the existence of previous disturbance in the area to be reviewed; 3 ) the cultural resource sensitivity of the area in which the activity is planned; and 4) whether the project involves any existing structure or building. Using these criteria, projects may fall into any one or more of the following six project classes: Class I) maintenance in a disturbed, low-sensitivity area; Class II) maintenance in a disturbed, high-sensitivity area; Class III) new construction in a disturbed low-sensitivity area; Class IV) new construction in a disturbed, high-sensitivity area; Class V) all projects involving undisturbed ground; and Class VI) projects involving demolition or remodeling of buildings or structures. Each class requires a different response, as specified in Section 3 of the HCRMP. The following subsections describe reviews conducted in FY 1994. 


\subsection{Reviews Conducted}

During FY 1994, Hanford contractors requested 511 cultural resources reviews. Most cases initiated this year were Class III reviews (275), followed by Class I (104), Class VI (79), Class V (16), Class IV (18), mixed Class III/V (6), Class II (2), and one each of the mixed Classes, I/VI, III/VI, IV/

$\mathrm{VI}$, and V/VI. In addition, four projects involved land transfers and/or easements that did not fit into any specific Class, and two Class unknowns (other contractors) and one project initiated in a previous year, was completed. The majority of the reviews were requested for the 200 Areas (251), followed by the 300 and 600 Areas (94 and 67 respectively), and the 100 Area (60). The remainder of reviews were fairly equally divided between the 400,1100 , and 3000 Areas, and DOE-administered lands outside of the Hanford Site boundaries. See Appendix A for a list of all projects reviewed in FY 1994.

Class I projects are defined as maintenance in a disturbed, low-sensitivity area. Class I cases must be formally requested by Hanford contractors and reviewed by the HCRL. Because these projects require maintenance work on existing facilities. only, the project area has been previously disturbed. The focus of the review for these projects, therefore, is not to determine the disturbance level but determine if the project will occur in a culturally sensitive location. The review includes an examination of site and sensitive area location maps.

Class II and Class IV projects are defined as maintenance (Class II) or new construction (Class IV) in have been destroyed by previous construction.

Class III projects are defined as new construction in a disturbed, low-sensitivity area. A.ll Class III projects must be formally requested and reviewed. The focus of these projects is to determine the level of previous disturbance in, and sensitivity of, the project area. The review includes an examination of recent aerial photographs, site and sensitive area location maps, and, if necessary, records associated with any nearby surveys and/or sites.

Class $\mathrm{V}$ projects are defined as projects involving undisturbed ground. They nearly always require a survey, if one previously has not been conducted of the area. Reviews of these areas include an examination of aerial photographs to determine if the entire project area is undisturbed, an examination of site and survey maps to determine if any sites exist or surveys have been done on or near the project area, and, if necessary, a records review of information associated with these sites and surveys. In FY 1994, the HCRL initiated 29 Class V cases requiring survey (see Appendix $B$ ) and one survey requiring monitoring. One project required survey in FY 1994 that was initiated in the previous year. 
Thirty surveys were completed totaling approximately $11.35 \mathrm{~km}^{2}$. The largest surveys conducted were the Basalt Quarry Sites survey, which covered a total area of $3.24 \mathrm{~km}^{2}$ and the Tank Waste Remediation Systems (TWRS) survey, which covered $2.72 \mathrm{~km}^{2}$. The majority of the surveys occurred in the 600 Area (19), followed by the 200 Area (3), and the 100 and 300 Areas ( 2 each). In addition, 13 site visits were conducted in FY 1994 as part of cultural resources reviews. Surveys conducted as part of Section 106 reviews are listed in Table A.1

Class VI projects are defined as projects involving demolition or remodeling of buildings or structures. In FY 1994, 90 Class VI projects were requested of HCRL. Thirteen of the projects involved building demolition, while 82 involved building modifications, which required research into the construction date

\subsection{Cultural Resources Identified}

Thirty five previously unrecorded archaeological sites were recorded in FY 1994 (see Appendix D). Eight of the sites were recorded during the Basalt Quarry Sites (94-600-003) project. Eight sites were recorded during field visits for the McGee Ranch Mitigation Plan (94-600-045). The majority of the newly recorded sites are historic, dating from the late 1800 s to the Cold War era. The early historic sites may yield new information on early Euroamerican

\subsection{Large Survey Projects Completed}

Five large projects involving surveys were completed in FY 1994: the Basalt Quarry Sites, TWRS complex, Environmental Molecular Sciences Laboratory (EMSL), Spent Nuclear Fuels Storage Facility (SNFSF), and Environmental Restoration Disposal Facility (ERDF). of the facility and how it had been used since construction. From that information, a decision about the building's eligibility for inclusion in the National Register is made. If the facility is potentially eligible for the National Register, the HCRL staff determines if the project will affect any characteristics of the facility that would make it eligible. If the project will adversely affect the facility, further measures to mitigate the impacts would be taken. If there will be no effect, or if the facility is not potentially eligible for the National Register, a letter is written that states that either the facility is not eligible or that it is eligible but the project will not affect any characteristics of the facility that would make it eligible. In FY 1994, a total of 64 buildings were formally documented and forwarded to DOE-RL for Class VI projects (see Appendix C).

ranching and settlement activities in the Hanford area, and the latter sites may reveal information concerning Hanford Site activities during the early Cold War era. The prehistoric sites recorded this year may provide additional information about past resource use and subsistence patterns. Forty-one previously unrecorded archaeological isolates were identified in FY 1994 (see Appendix E). 


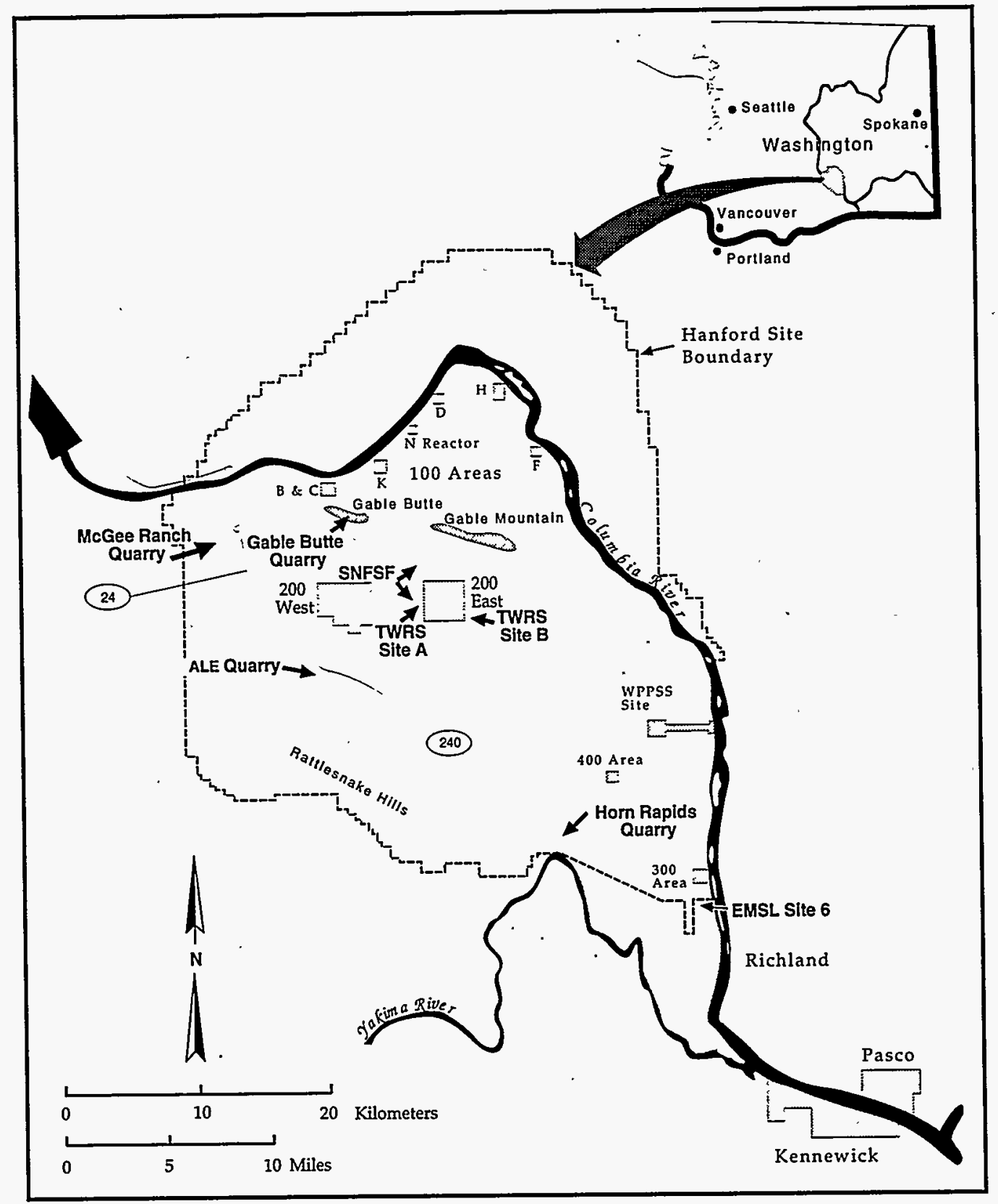

Figure 2.1 Location of Large Survey Projects Completed in FY 1994

2.4 


\subsubsection{The Basalt Quarry Sites HCRC \#94-600-003}

\section{Project Description}

Survey for the Basalt Quarry Sites was conducted as part of a cultural resources review for seven locations identified by Westinghouse Hanford Company as potential basalt sources on the Hanford Site. One or more basalt sources or quarries needs to be developed to supply basalt riprap and gravel for protective barrier construction projects expected to take place over the next several decades at Hanford. Seven areas were proposed for the quarries; the Fitzner/ Eberhardt Arid Lands Ecology (ALE) Reserve (2.12 $\mathrm{km}^{2}$ ), Gable Butte $\left(1.35 \mathrm{~km}^{2}\right)$, Gable Mountain (0.79 $\left.\mathrm{km}^{2}\right)$, Horn Rapids $\left(2.05 \mathrm{~km}^{2}\right)$, McGee Ranch (1.68 $\left.\mathrm{km}^{2}\right)$, Vernita Quarry $\left(0.79 \mathrm{~km}^{2}\right)$, and West Haven $\left(1.06 \mathrm{~km}^{2}\right)$. About $50 \%$ of three of these sites, Gable Mountain quarry, Vernita quarry, and West Haven quarry, and part of the McGee Ranch quarry had been previously surveyed in connection with other projects. To compare the seven potential quarry sites in terms of impacts to cultural resources, field surveys of a comparable percentage of the other four sites were required to identify extant cultural resource properties within their boundaries. To complete a $50 \%$ survey of the McGee Ranch quarry site, HCRL surveyed $0.48 \mathrm{~km}^{2}$ on February 14 and 15, and March 1 and 8, 1994. CH2M HILL, under subcontract to Pacific Northwest National Laboratory, surveyed about $50 \%$ of the ALE quarry site $\left(1.06 \mathrm{~km}^{2}\right)$, Gable Butte quarry site $\left(0.68 \mathrm{~km}^{2}\right)$, and the Horn Rapids quarry site $\left(1.02 \mathrm{~km}^{2}\right)$ on July 6-8 and 13-16, 1994 (Bard et al. 1994) (Figures $2.2-2.5)$. A total area of $3.24 \mathrm{~km}^{2}$ was surveyed for this project this year.

Survey Results

Seven isolates and four sites were identified at the $\mathrm{McGee}$ Ranch quarry, three isolates were discovered in the ALE quarry, 13 isolates and three sites were found in the Gable Butte quarry, three isolates were found in Horn Rapids quarry, and one site, HT-90-016, was re-located and re-recorded. These isolates and sites are summarized in Table 2.1.

Bard et al. (1994) made a preliminary analysis for eligibility of sites and isolates for listing in the $\mathrm{Na}$ tional Register. They concluded that sites HT-94026 and HT-90-016, and isolates HI-94-020, -025, $.029,-038$, and -039 may be eligible; however, in each case, additional research would be required to determine National Register eligibility. Also, some sites and isolates, while probably ineligible by themselves, when aggregated with other nearby sites and isolates could qualify as contributing elements to an archaeological district. They also discuss the traditional cultural properties of Gable Mountain and Gable Butte. Bard recommends that

...the ALE and Horn Rapids areas are the least sensitive in terms of cultural resources and that these proposed quarries should be given first consideration for development. Prior to developing any of the quarries, the selected quarry (s) should be subject to a complete (100 percent) inventory ... and that all recorded sites and isolates be formally evaluated for their eligibility to be listed in the National Register of Historic Places.

In the event that rock quarrying is found to be infeasible at the ALE and Horn Rapids quarries and that one or more of the five remaining quarries must be developed, we recommend that the five quarries be subject to a complete (100 percent) inventory. Once a complete inventory has been accomplished, 
- paypipyssods

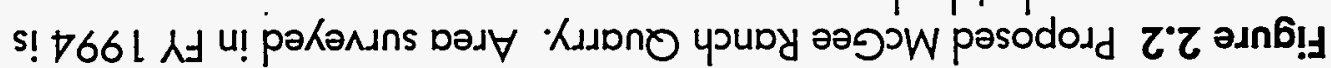

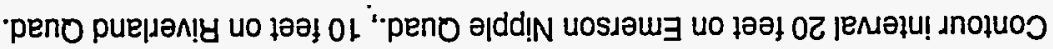
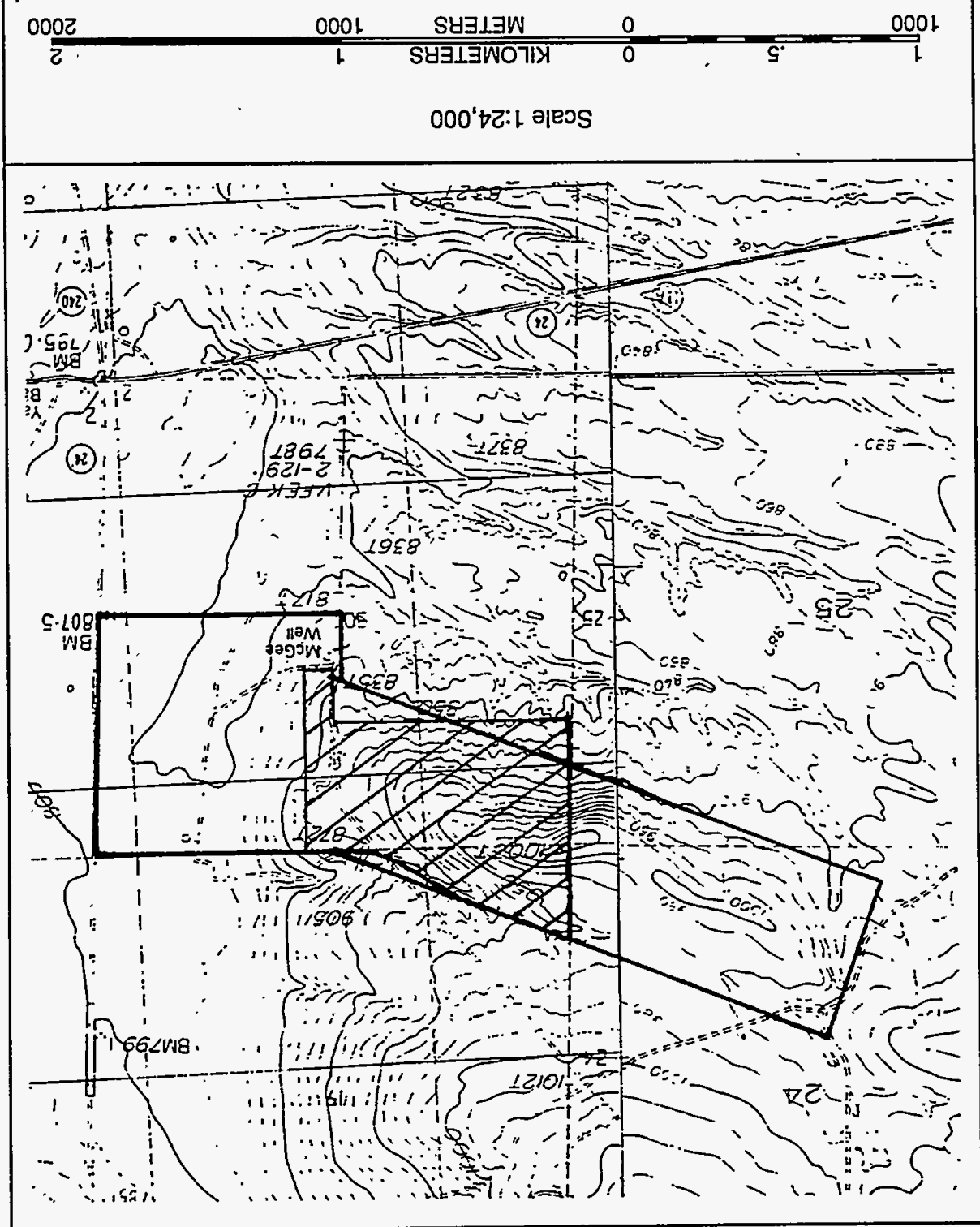

$N \varepsilon+\perp$

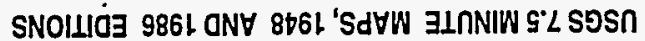

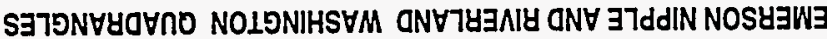




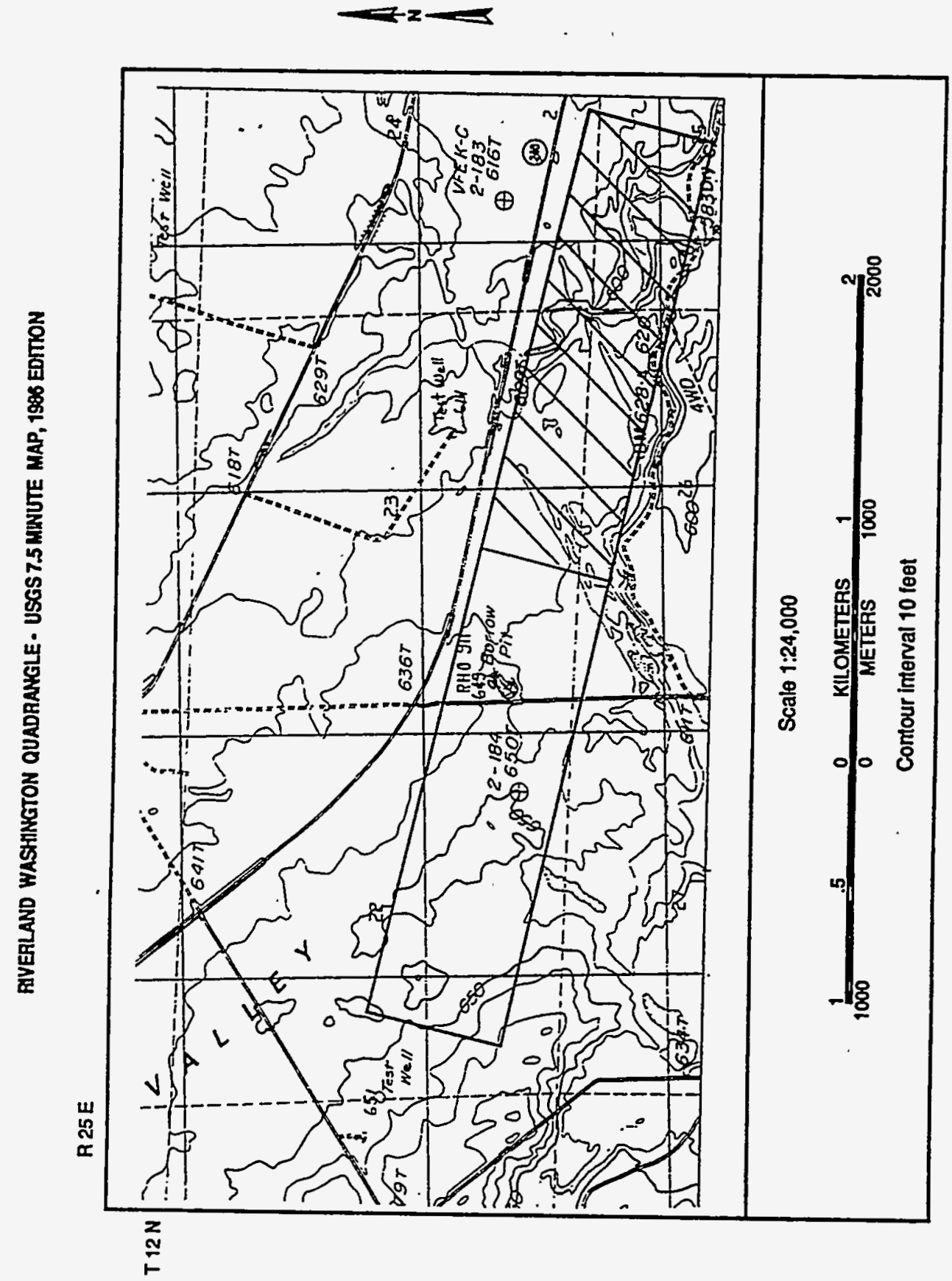

Figure 2.3 Proposed ALE Quarry. The survey area is crosshatched. 
GABLE BUTTE WASHINGTON QUADRANGLE - USGS 7.5 MINUTE MAP, 1986 EDITION

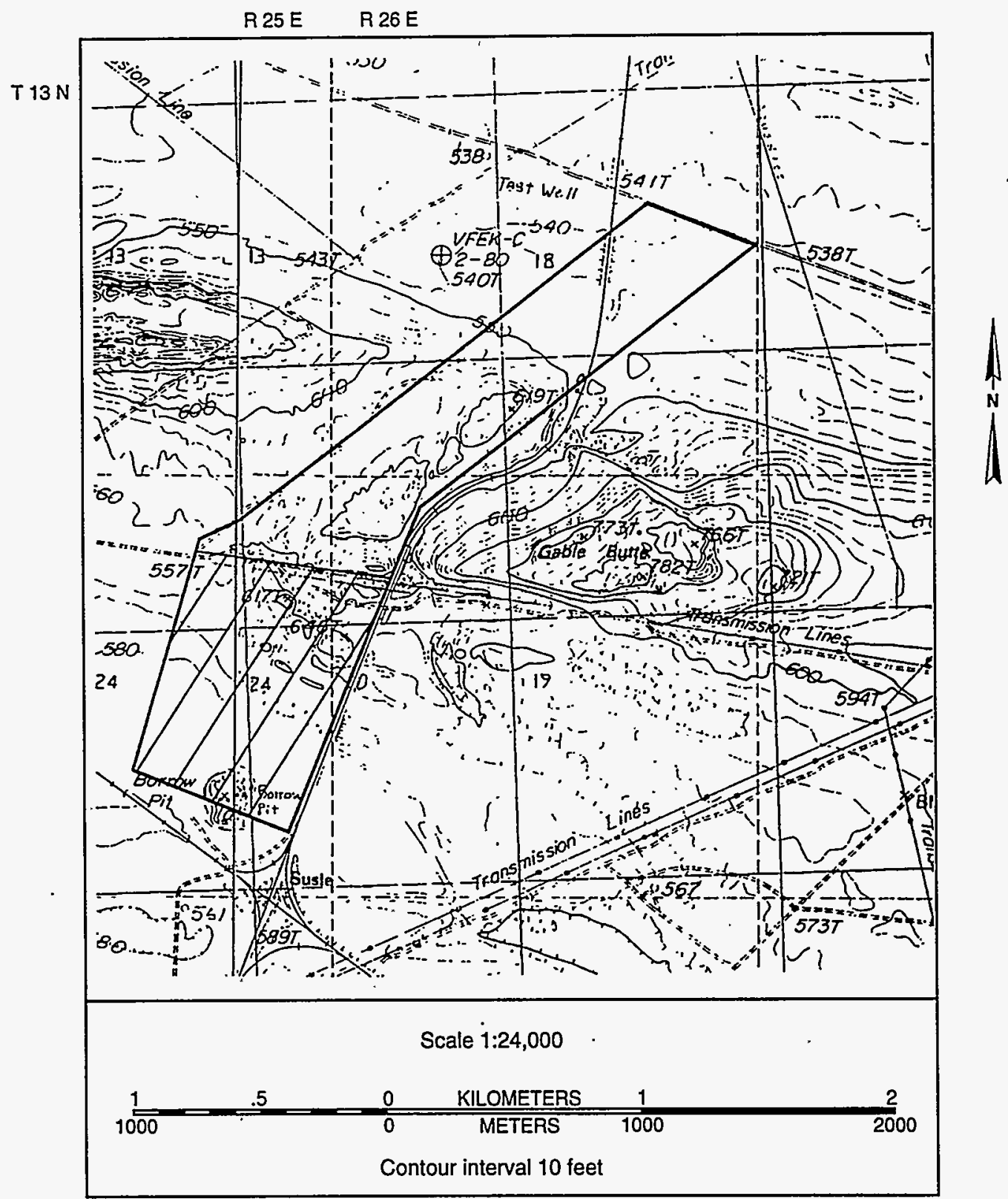

Figure 2.4 Proposed Gable Butte Quarry. The survey area is crosshatched. 
HORN RAPIDS DAM, WASHINGTON QUADRANGLE - USGS 7.5 MINUTE MAP, 1977 EDITION

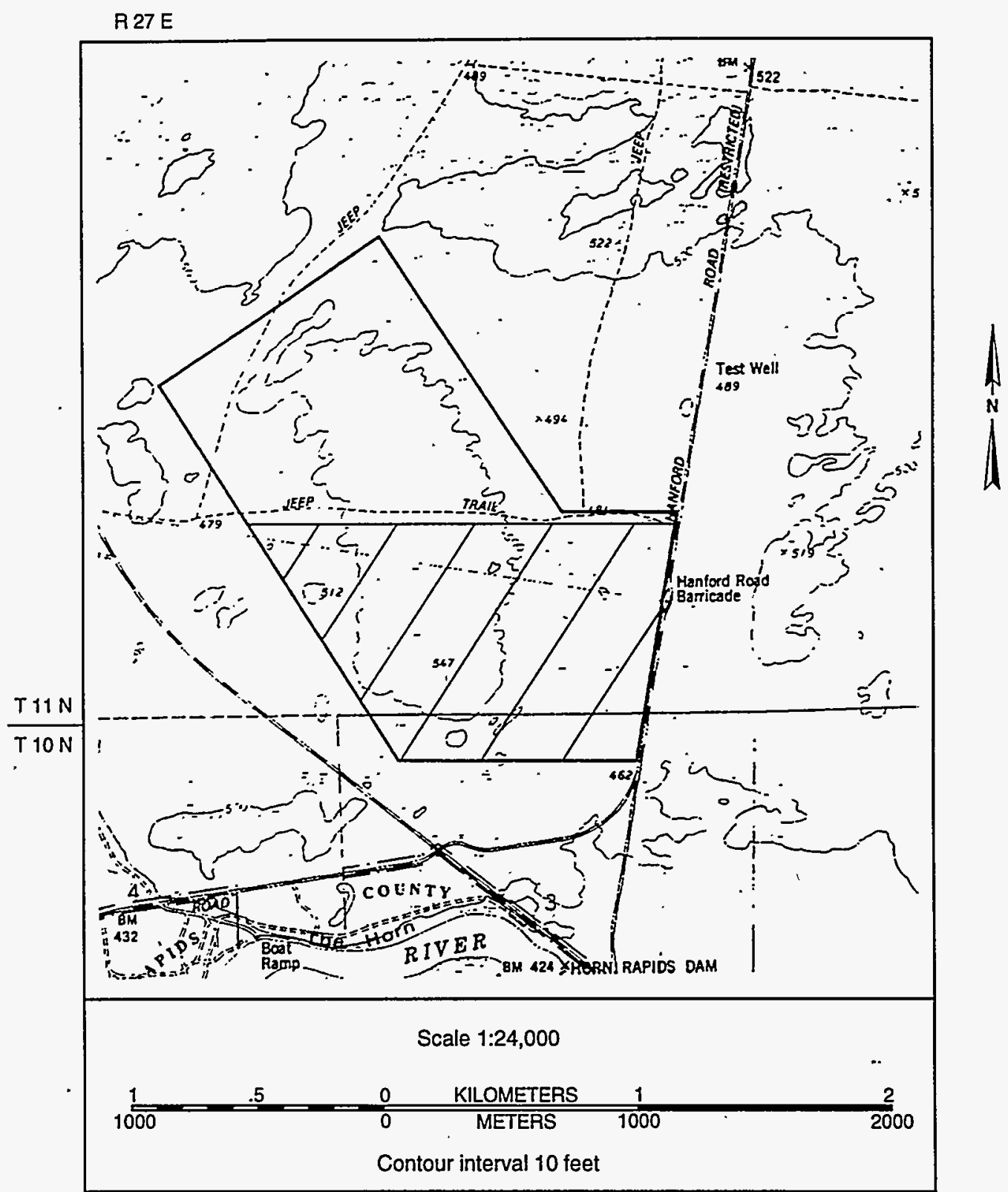

Figure 2.5 Proposed Horn Rapids Quarry. The survey area is crosshatched. 


\section{Table 2.1 Sites and Isolates Recorded During Survey for the Proposed}

Basalt Quarries

\section{McGee Ranch}

Site/Isolate Number

$\mathrm{HI}-94-004$

HI-94-005

HI-94-006

HI-94-007

HI-94-008

$\mathrm{HI}-94-012$

$\mathrm{HI}-94-013$

HT-94-009

HT-94-010

HT-94-015

HT-94-011

\section{Description}

Two secondary flakes, one petrified wood, the other red/brownbanded crypto-crystalline silicate (CCS) possibly used.

Basal-notched projectile point fragment, similar to those described in the Cayuse I Subphase of Nelson (1969).

Basal-notched, petrified wood projectile point. The point is similar to Quilomene Bar as described by Nelson (1969) and to the Harder Phase points as described by Leonhardy and Rice (1970).

Two clear and white CCS flakes, one with a utilized edge.

Contracting stem projectile point fragment made of white and caramelcolored CCS. The point is similar to points described as Frenchman . Springs in Nelson (1969).

A red/brown CCS flake, one edge shows possible wear.

Broken brown CCS thinning flake.

Sparse lithic scatter consisting of one red CCS flake and three white and clear CCS flakes.

Rock features of uncertain cultural affiliation composed of $25+$ cobbles and large pebbles in an area $0.85 \mathrm{~m} \times 0.85 \mathrm{~m}$ located on the edge of a major gully. The rocks are predominantly granitic with a few quartzites and metasediments.

Multicomponent site consisting of flour flakes, one biface fragment, a rock cairn, either the remains of an old section corner cairn 17879 GLO survey?) or prehistoric Native American origin along with three lengths of heavy gauge wire, milled wood fragments, downed fence posts, and fence jacks (supporting rock poles).

Small cairn of uncertain culfural affiliation. Possibly of prehistoric Native American origin.

\section{Fitzner/Eberhardt Arid Land Ecology Reserve}

Site/Isolate Number

$\mathrm{HI}-94-032$

HI-94-036

HI-94-037

\section{Description}

Two white CCS flakes.

Historic "fence jack" - rock pile with remains of a split rail.

Large historic riveted metal-collared cylinder. 


\section{Gable Butte}

Site/Isolate Number

HI-94-020

HI-94-021

HI-94-022

HI-94-023

HI-94-024

HI-94-025

HI-94-026

HI-94-027

HI-94-028

HI-94-029

HI-94-030

HI-94-031

HI-94-035

HT-94-024

HT-94-025

HT-94-026

\section{Horn Rapids}

\section{Site/Isolate Number} HI-94-038

HI-94-039

$\mathrm{HI}-94-040$

HT-90-016

\section{Description}

A small rock ring of uncertain cultural affiliation. Believed to be of prehistoric Native American origin.

Two historic tin cans.

Two historic tin cans, ca. 1920 A.D.

One historic tin can.

One historic tin can, ca. 1910 A.D.

A rock feature that might once have served as a hunting blind at the mouth of a small canyon pass. Rock wall is of uncertain cultural affiliation, but believed to be of prehistoric Native American origin.

A low rock wall across a narrow, U-shaped canyon pass, of uncertain culfural affiliation but believed to be of prehistoric Native American origin. May be an extensive hunting blind or related to prehistoric game drives.

A proximal/medial section of a chalcedony thinning flake.

A bottom and side fragment of a rectangular historic amethyst bottle.

A 4- $f$ high rock cairn of uncertain cultural affiliation but may be of prehistoric Native American origin.

Two historic tin cans.

A small historic metal lamp fragment.

A small compact rock cairn of uncertain cultural affiliation, but believed to be of historic origin. May have helped secure a fence post.

A historic can scatter, with condensed milk cans dating to ca. 1900 A.D.

A historic can scatter.

Three rock features (cairns) of uncertain cultural affiliation. A piece of milled lathe is lying across one of the cairns. A tobacco can was found with one of the cairns. At least one of the rock features is believed to be prehistoric but the presence of the milled lathe and a tin can sugges possible historic origin.

\section{Description}

-A basal cobble ring of uncertain cultural affiliation but believed to be of prehistoric Native American origin.

A rock feature of uncertain cultural affiliation but believed to be of prehistoric Native American origin.

A round aluminum historic tax token.

(Previously recorded in 1990) A multicomponent site with semi-circular rock wall, historic glass fragments and tin cans and prehistoric artifacts. 
an objective determination of which of the five remaining quarries are less sensitive in relation to the others can be made. Once the quarry site(s) is selected and it has been subject to a complete archaeological inventory, all recorded sites and isolates should be formally evaluated for their eligibility for listing in the National Register of Historic Places.
National Register eligibility evaluations should also consider the presence of traditional cultural properties (TCPs). Coordination and consultation with interested tribes will be a required element in the evaluation of prehistoric sites and isolates as physical evidence of TCPs.

\subsubsection{Tank Waste Remediation Systems Complex HCRC \#94-600-054 HCRC \#94-600-060}

\section{Project Description}

This project will involve the construction of a TWRS complex in the general vicinity of the 200 East Area of the Hanford Site. The cultural resources review and survey were completed as required by Section 106 of the NHPA. The results were incorporated into the TWRS Environmental Impact Statement (EIS) for Westinghouse Hanford Company. Three possible sites for the TWRS complex were identified in FY 1994. They were designated Sites A, B, and $C$. The three sites were assigned two project numbers (HCRC $\# 94-600-054$, Sites $A$ and $C$, and $\# 94$ 600-060, Site B). A survey was conducted for Sites $A$ and $B$, while no new survey was required for Site C. See Figures 2.6 and 2.7 for maps of the proposed sites $\mathrm{A}$ and $\mathrm{B}$.

\section{HCRC \#94-600-054}

This project included both Sites $A$ and $C$. No new survey was required for Site $C$, because the records search revealed that the entire project area had either been surveyed for previous projects or was too disturbed by Hanford Site activities to warrant a survey. The proposed Site A covered an area mea- suring $2.81 \mathrm{~km}^{2}$; however, much of the area did not require survey as it had either been previously surveyed or was within a gravel pit, which was actively being mined. After extensive pre-field research was completed, a pedestrian survey of $1.42 \mathrm{~km}^{2}$ was conducted between July 7 and July 13, 1994.

The survey area was located on the landform locally known as the 200 Area Plateau, to the west of Route 4 South. The surface topography was low-relief stabilized dunes consisting of silt to fine sand. Elevations in the project area ranged from 650 to $756 \mathrm{ft}$ above sea level (asl). The closest source of permanent water is the Columbia River, approximately 12.5 $\mathrm{km}$ to the east. A spring at West Lake is located 3.4 $\mathrm{km}$ from the northeast corner of the project area and may have provided an intermittent source of water.

\section{Survey Results}

Several archaeological sites and isolated artifacts were known to exist in the previously surveyed areas of Site $A$ and in the immediate vicinity. Within the Site $C$ project area, one isolated artifact was previously recorded as were two isolated artifacts located just outside the Site $\mathrm{C}$ project boundary. Two previ- 
ously unrecorded isolated finds, HI-94-045, a CCS flake, and HI-94-046, two CCS flakes, were discovered during the July 1994 survey.

\section{HCRC \#94-600-060}

The proposed Site B included a total area of 2.3 $\mathrm{km}^{2}$. A large amount of the area had been previously surveyed or extensively disturbed by Hanford-related projects, including the former Grout Facility. After an extensive records search, an archaeological survey of $1.3 \mathrm{~km}^{2}$, covering previously unsurveyed portions of the project area, was conducted between
August 29 and September 14, 1994. Site B is located east of the 200 East Area of the Hanford Site, east of Canton Avenue on the 200 Area Plateau. The environmental setting is similar to that of Site $\mathrm{A}$.

\section{Survev Results}

No new cultural resources were discovered during the Site B survey. Of the existing resources identified in previous surveys, two historic isolated artifacts (HI-88-024 and HI-88-025) were located within the project area. During the survey various areas of modern debris were noted, but not formally recorded. 
GABLE BUTTE WASHINGTON QUADRANGLE - USGS 7.5 MINUTE MAP, 1986 EDITION

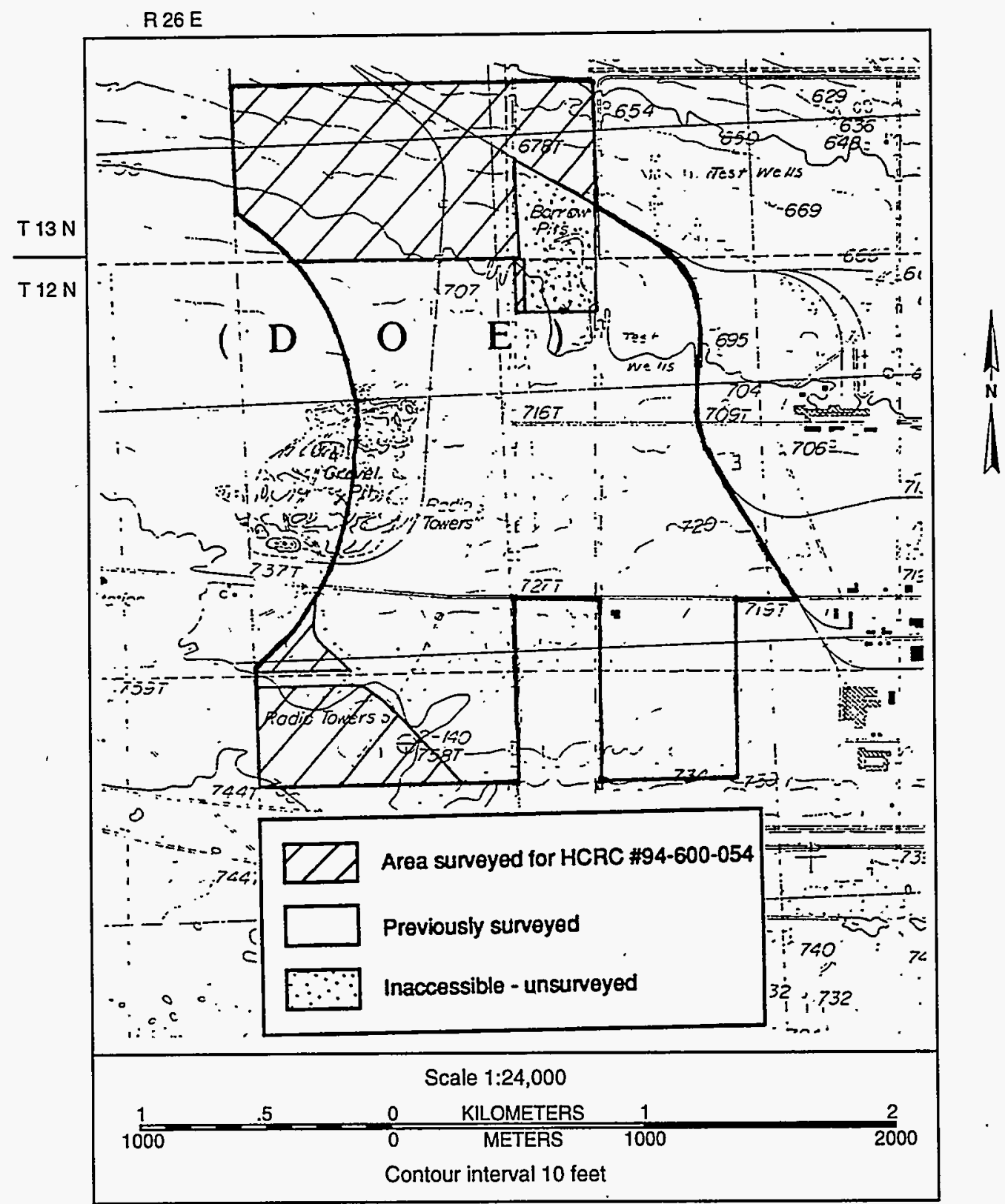

Figure 2.6 Proposed TWRS Site A 
GABLE BUTTE AND HANFORD WASHINGTON QUADRANGLE S USGS 7.5 MINUTE MAPS, 1986 EDITIONS

R $26 E$

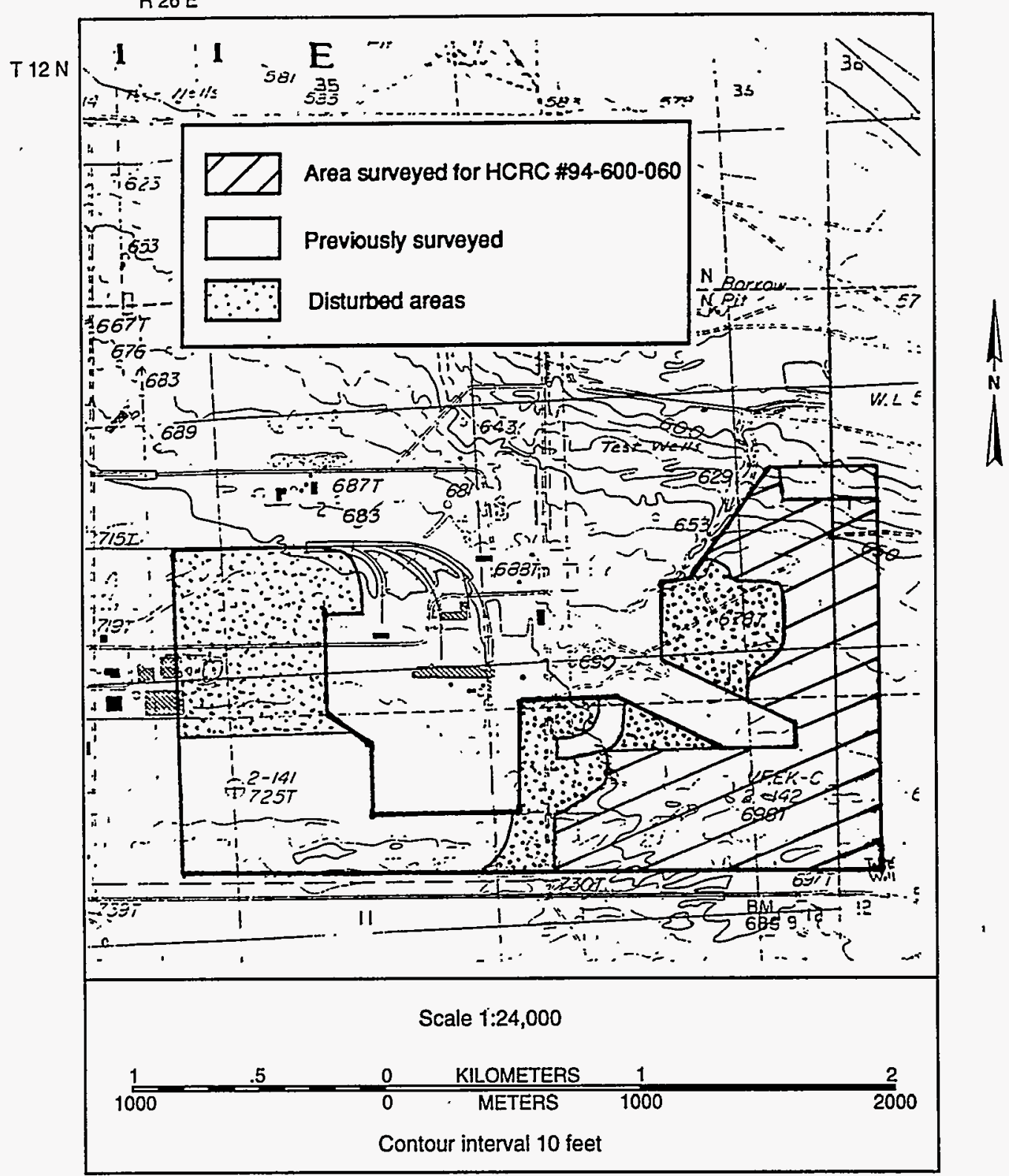

Figure 2.7 Proposed TWRS Site B 


\subsubsection{The Environmental Molecular Sciences Laboratory HCRC 94-3000-002}

The DOE has established a new mission for the Hanford Site that includes the EMSL, which is designed to provide facilities to the develop new technologies to manage and handle waste sites. Construction activities for this new facility began in April 1994, but were stopped within 24 hours following the discovery of human remains. As a result of this discovery, the original EMSL site was abandoned, and a new location was selected. Investigations to determine the presence or absence of cultural resources at the new location, EMSL Site 6 (Figure 2.8), located approximately $4 \mathrm{~km}$ north of Richland, Washington, and $0.8 \mathrm{~km}$ west of the Columbia River began immediately.

EMSL Site 6 was surveyed by Pacific Northwest National Laboratory archaeologists on April 25, 1994, following a background and literature review, which revealed that Site 6 had been modified by numerous historic activities, including the installation of an irrigation canal, farming activities, and the construction of Camp Hanford. The field survey of Site 6 verified the 1) presence and later demolition of the irrigation canal and Camp Hanford, 2) presence of dunes in the northwest corner, and 3) need for additional investigations, including remote sensing and subsurface tests.

Subsequent investigations included subsurface testing at geophysical borehole locations, remote sensing of subsurfaces, and excavation of test units to investigate anomalies noted during remote sensing activities. The excavation objectives were twofold: to 1) determine the depth of soil/sediment deposits, and 2) identity subsurface anomalies.

As a result of these efforts, a high degree of confidence was reached that the construction of the EMSL complex at Site 6 would not impact buried cultural materials within the eastern portion of the alfalfa field. However, it was recommended that 1) construction activities be avoided at the northwest corner of the alfalfa field be because of the depths of dune sand in that area, and 2) monitoring be required of EMSL excavation activities to Pleistocene gravel by Native Americans and HCRL archaeologists. 


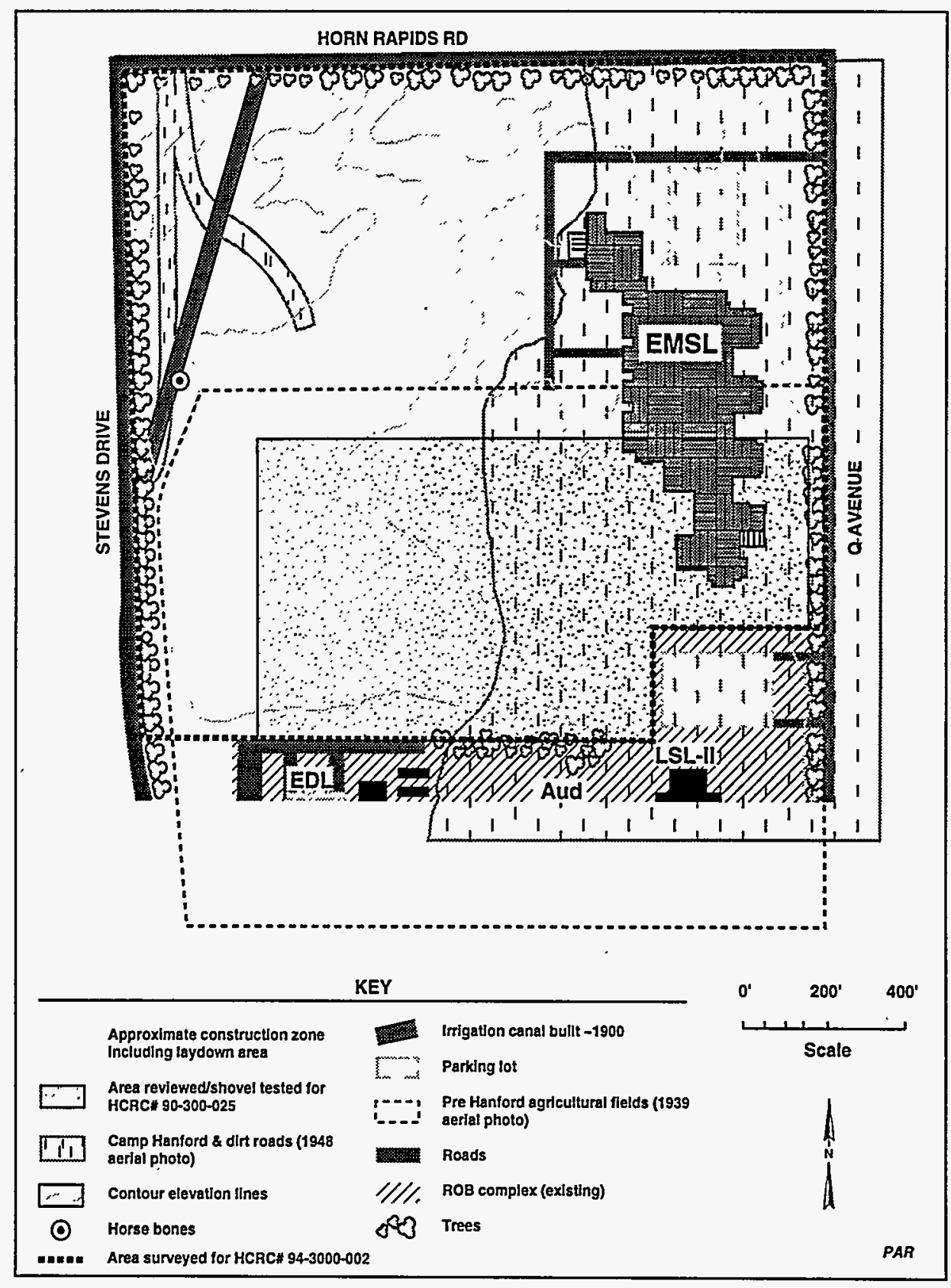

Figure 2.8 Area Surveyed for the EMSL, Site 6 


\subsubsection{Spent Nuclear Fuels Storage Facility}

\section{Project Description}

Two possible sites for the SNFSF were identified and surveyed during FY 1994 (HCRC \#94-600-001 and $\# 94-600-017$ ), at the request of Pacific Northwest National Laboratory for the EIS for the SNFSF, which might be sited on the Hanford Site.

\section{HCRC \#94-600-001}

The first proposed project area measured $0.74 \mathrm{~km}^{2}$ and was located in an area locally known as the 200 Area Plateau to the west of Route 4 south and north of Route 3 to the west of the 200 East Area (Figure 2.9). The southwest part of the project area was within a gravel pit that was actively being mined. Because the possibility of cultural resources in these Pleistocene flood gravels was very remote, the gravel pit was not surveyed for this project. A total of $0.63 \mathrm{~km}^{2}$ was covered by the survey, which was conducted on October 22, 1993. The remainder of the area was largely undisturbed. Disturbances included a borrow pit, roads, pipelines, a railroad line, and disturbance as the result of a tower removal.

The surface topography is low-relief stabilized dunes composed of fine sand and silt. The land surface slopes very gently to the northeast with elevations ranging from $213 \mathrm{~m}$ ( $700 \mathrm{ft}$ ) asl to $226 \mathrm{~m}$ ( $740 \mathrm{ft}$ ) asl. The closest source of perennial water is the Columbia River, which is located, at its closest point to the project area, approximately $10 \mathrm{~km}$ to the northwest.

\section{Survey Results}

One isolated artifact, a CCS flake (HI-94-003), was found in the project area. A number of recent artifacts were noted but not formally recorded. These included a sledge hammer used on the railroad, a 6 1/2 fluid oz Coca Cola bottle with LOS ANGELES, CA, embossed on the base of the bottle, a sardine can, metal roofing, two steel beverage cans, one marked "Toddy Chocolate Malt Flavored Milk," a metal-framed screen, and a sausage-type can with a $\mathrm{key} / \mathrm{tab}$ type of opening.

\section{HCRC \#94-600-017}

The second area considered for the SNFSF was south of Route $11 \mathrm{~A}$ and to the west of Route $4 \mathrm{~S}$ within the NE $1 / 4$ of Section 33 and the NW 1/4 of Section 34, T 13N R 26E (Figure 2.10). The project area was surveyed on May 16, 1994. A total of $0.78 \mathrm{~km}^{2}$ was surveyed for the project review.

The project area was on the northern edge of the 200 Area Plateau. The land surface slopes gently to the north-northeast, and an escarpment trends east/ west in the north half of the project area. Elevations range from $170 \mathrm{~m}$ asl to $201 \mathrm{~m}$ asl. The ground surface is fairly level with small vegetation hummocks. The surface sediments are eolian sands and silt with varying amounts of pebble lag. Depth of Holocene eolian sediments overlying Pleistocene gravels is estimated at over $1.5 \mathrm{~m}$ as suggested by sediments exposed in an old borrow pit and subsurface excavations by badgers. Eolian sediments are more shallow below the escarpment where gravels were visible in an old borrow pit about $0.5 \mathrm{~m}$ below surface. Boulders, mostly buried, were visible on the escarpment slope. The closest source of perennial water is the Columbia River, which is located, at its closest point to the project area, $8.5 \mathrm{~km}$ to the northwest. A spring at the present site of West Lake, located $3 \mathrm{~km}$ to the northeast of the project area, may have provided water intermittently in the past. The project area is 
located about $3.5 \mathrm{~km}$ to the south of Gable Mountain and Gable Butte, sacred landforms to the Wanapum and Yakama peoples, both are considered traditional cultural properties. Gable Mountain and Gable Butte are considered to be eligible for listing in the National Register.

Previous disturbances in the project area included 1) a deteriorating asphalt road, the remains of part of the $3200-\mathrm{m}$ arc road used from $1960-1974$ for atmospheric dispersion tests, a 2) railroad line that passes through the southwestern corner of the project area constructed to support Hanford Site activities (several dirt roads parallel the railroad), 3) several bladed areas parallel to and adjacent to Route $11 \mathrm{~A}$ and Route 4 , which appear to be borrow pits, 4) a revegetated strip parallel to Route 11, which may be remnants of an old power-line, and 5) a north/south-trending berm near the western edge of the project area (fence line?).

\section{Survey Results}

Two isolated artifacts were identified as a result of the survey. Artifacts identified were an isolated CCS flake, HI-94-016, and a coffee pot, HI-94-017. Several artifacts were noted but not formally recorded, including a sanitary can, a tobacco can, a wine bottle, and $\mathrm{C}$-ration cans.

If the project is built on this site, there will be no direct impacts to any known historic property. However, there could be indirect impacts on the traditional cultural properties of Gable Mountain and Gable Butte, including visual impacts and noise. Such impacts may be considered adverse according to provisions in the AIRFA. 
GABLE BUTTE WASHINGTON QUADRANGLE - USGS 7.5 MINUTE MAP, 1986 EDITION

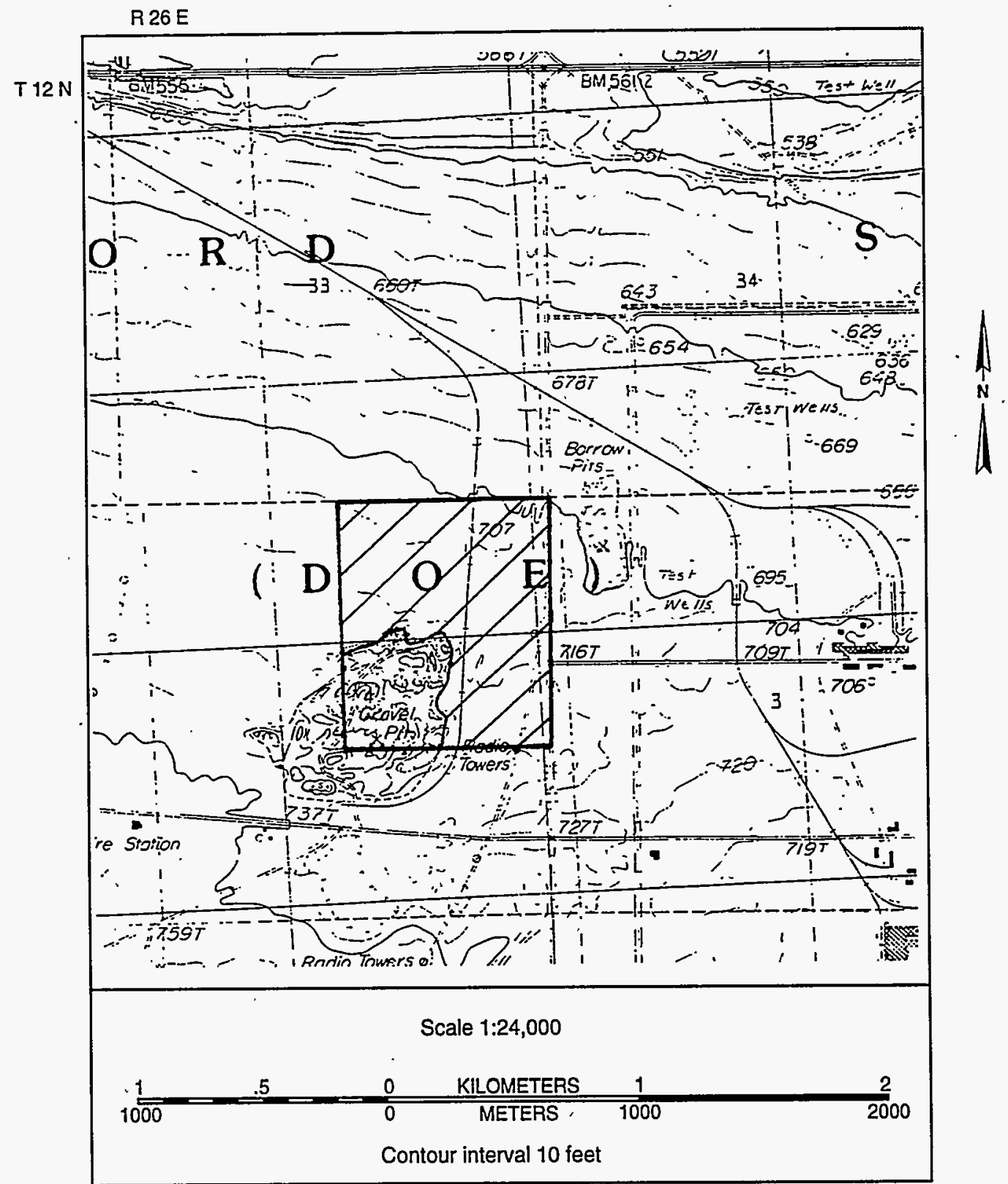

Figure 2.9 Proposed SNFSF, HCRC \#94-600-001. The area surveyed is crosshatched. 


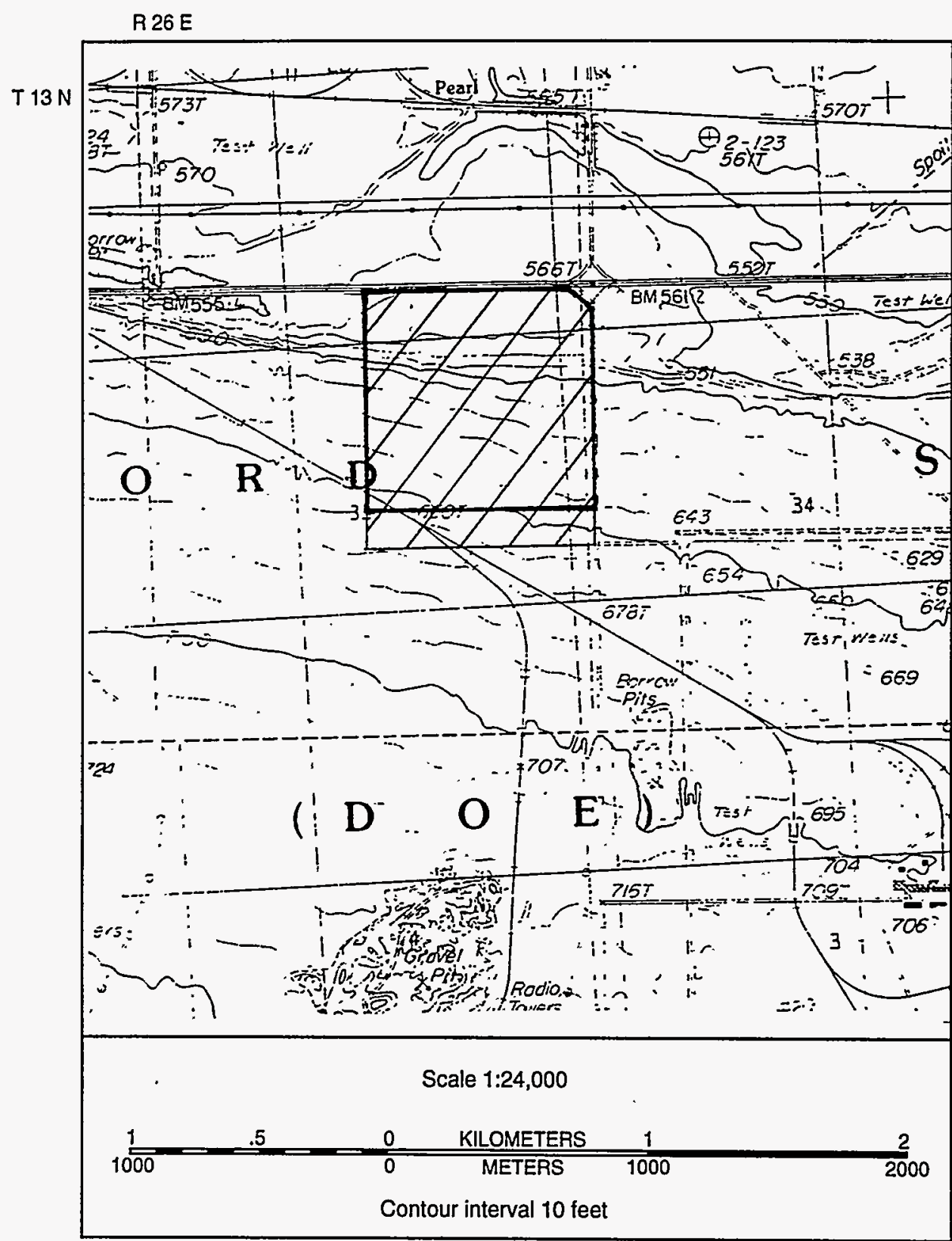

Figure 2.10 Proposed SNFSF, HCRC \#94-600-017. The area surveyed is crosshatched. 


\subsubsection{Environmental Restoration Disposal Facility Northeast Portion}

\section{Project Description}

The ERDF will provide the disposal site for the waste exhumed during the Hanford Site CERCLA and RCRA cleanup actions. The majority of the project area $\left(11.0 \mathrm{~km}^{2}\right)$ was surveyed in FY 1993 (HCRC \#93-200-001). An additional $1.1 \mathrm{~km}^{2}$ on the northeast side of the area was identified for the project in FY 1994 (HCRC \#94-600-034). The impacts on the area would be severe. All surface and subsurface matrix would be disturbed to a depth of up to $12 \mathrm{~m}$. The project area was surveyed on.June 16 and 17,1994 , by HCRL. The project area is on the 200 Area Plateau. The area is characterized by a series of stabilized sand dunes that were about $6 \mathrm{~m}$ from peak to trough and between 30 to $50 \mathrm{~m}$ apart. The sand dunes trended along an east/west axis. At the south end of the project area the dunes gave way to an extensive plain.

\section{Survey Results}

The project area has a commanding view of Rattlesnake Mountain, which is a cultural property of importance to several Native American tribal groups. The viewshed of Rattlesnake Mountain potentially could be affected if the project occurs.

Two isolated artifacts were identified, HI-94-018 and HI-94-019. HI-94-018 was an historic isolated metal can with crimped edges, opened by a can opener at one end. It measured 4 in. in diameter and was about 4 10/16 in. HI-94-019 was a black-sheathed communication line on the ground surface along with a series of metal rods that were part of the batteries that ran the communication system. This isolate is probably related to military activities on the Hanford Site in the 1950 s or 1960 s. Neither artifact meets criteria for listing in the National Register. 


\subsection{National Historic Preservation Act Section 110 Compliance Reviews}

This section describes Section 110 of NHPA compliance reviews for FY 1994. Section 110 requires DOE to locate, inventory, nominate, and protect properties eligible for the National Register; document historic properties adversely affected by federal undertakings and assume responsibility; undertake preservation; and use historic properties (buildings) whenever possible. Consultation with interested persons, tribes, the SHPO, and the Advisory Council is required to resolve adverse effects of federal undertakings. Section 110 provides direction to establish mechanisms by which comments by consulting parties are to be obtained.

\subsection{Determinations of Eligibility}

Federal agencies request determinations of eligibility during the process of considering historic properties on lands in their jurisdiction or control or on lands to be affected by proposed actions (36 CFR 63.1). Determinations of eligibility for the National Register were completed for six properties during FY 1994. HCRL staff completed work on the National Register of Historic Places Multiple Property Documentation Form for the Hanford Site throughout FY 1994.

\section{$45 \mathrm{BN} 423$}

This site is one of six archaeological sites discovered near Coyote Rapids in 1991 (Chatters, Gard, and Minthorn 1992:18). It is thought to be connected with significant religious events associated with the Washani religion. Test excavations conducted during the 1992 field season exposed a stratigraphically intact record of human occupation for a period spanning approximately 6000 years.
In FY 1994 the HCRL completed several tasks related to Section 110 compliance, including identification, evaluation, and monitoring of historic properties. Site monitoring activities from FY 1993 were completed early in FY 1994, and a letter report describing the results was forwarded to DOE in November 1993. Two tasks associated with the 100 Area were completed, including a summary report of HCRL field activities in FY 1993-1994 and a report on the $\mathrm{N}$-Springs area. The latter report includes the recording of the N-Springs vicinity as a traditional cultural property.

This site is significant because it contains potentially datable shell, faunal remains and intact stratigraphy. It was considered to be eligible for listing in the National Register under criterion (d) of 36 CFR 60.4 because it "...may be likely to yield information important in prehistory or history." Pertinent research issues include 1) refinement of the temporal and functional extent of intra-site activities, 2) consideration of the range of resource procurement, and 3) climatic reconstruction. The research potential of this site was determined to be exceptional due to undisturbed stratigraphic deposits and the excellent preservation of cultural materials.

A determination of eligibility form was submitted for this site on May 3, 1994. The SHPO concurred this site was eligible for listing in the National Register on May 17, 1994. 


\section{BN434}

This site is one of many prehistoric sites located at Coyote Rapids along the banks of the Columbia River in southeastern Washington and constitutes one localized area of use within the greater context of a multidimensional prehistoric and historic pattern of use on the Hanford Site and the surrounding environs. Written accounts and Native American oral histories underscore the importance of Coyote Rapids as a traditional cultural property. $45 \mathrm{BN} 434$ is one of several archaeological sites adjacent to Coyote Rapids.

A traditional cultural property is considered to be eligible for listing in the National Register if it is "a location associated with the traditional beliefs of a Native American group about its origins, its cultural history, or the nature of the world" (Parker and King n.d.). 45BN434 is considered to be eligible for listing in the National Register because of its age (ca. 8000 to 45000 yr B.P) and its association with Coyote Rapids, the location of the first Washat dance held by Smohalla, the first spiritual leader of the Washani religion. Although in some areas the integrity of 45BN434 has been impacted by natural and anthropomorphic impacts, large portions of 45BN434 are still natural. Further, 45BN434 is sandwiched between two significant locations, 45BN423 (eligible for the National Register) and Coyote Rapids.

Given the associations just described, 45BN434 was considered to be eligible for listing in the $\mathrm{Na}$ - tional Register under three of the four National Register criteria (36 CFR 60.4); criterion A: "Associated with events that have made a significant contribution to the broad patterns of our history," criterion B: "Associated with the lives of persons significant in our past," and criterion $D$ because it "...may be likely to yield, information important in prehistory or history."

A determination of eligibility form was submitted to SHPO for this site on June 27, 1994. The SHPO concurred it was eligible for listing in the National Register on May 31, 1995.

\section{BN446}

This site is located along the banks of the Columbia River. The Wanapum, Umatilla, Yakama, and $\mathrm{Nez}$ Perce Indians all have demonstrated patterns of traditional use on the Hanford Site. Within this context, the site is significant because of its value to $\mathrm{Na}$ tive American tribes and its association with the Columbia River (Relander 1987). Within the context of NHPA, 45BN446 is scientifically significant because it contains potentially datable shells, beads, diagnostic artifacts, and intact stratigraphy below 30 $\mathrm{cm}$ below surface.

Given the associations just described, 45BN446 is considered to be eligible for listing in the National Register under criterion D of 36 CFR 60.4 because it "...may be likely to yield information important in 
prehistory or history." At 45BN446, research questions include the temporal extent and functional range of past activities during the Frenchman Springs and Cayuse Phases and long-term versus short-term adaptations and/or multiple use through time along the Columbia River.

A determination of eligibility form was submitted to SHPO for this site on May 3, 1994. The SHPO concurred this site was eligible for listing in the $\mathrm{Na}$ tional Register on May 17, 1994.

$\underline{3-17}$

This historic site is one of numerous historic agricultural sites located along the banks of the Columbia River and constitutes one localized area of use within the greater context of a multidimensional prehistoric and historic pattern of use on the Hanford Site and surrounding environs.

Historic site 3-17 is representative of irrigated agricultural properties on the Hanford Site dating from the turn of the century to 1943 . Although the site has numerous irrigation remnants and other agricultural features, it lacks structural archaeological evidence of such to provide important interpretive information on settlement of the area, or specifically, knowledge of a farmstead on or near the site. Additionally, the field stands isolated from adjacent and/ or larger agricultural developments in the area. Impacts have occurred on all sides of the site because of earth-moving activities associated with road and levy construction, and construction of the B/C Reactor complex.

Although 3-17 has retained certain attributes of an irrigated agricultural property with its furrowed fields, rock walls composed of field cobbles, field markers, irrigation ditches, and underground water mains and related irrigation features, analysis of these re- mains adds little new or important information to our understanding of the agricultural development/irrigation history of the area to qualify, under criterion $D$, for listing in the National Register.

HCRL staff recommended that 3-17 was not eligible for inclusion in the National Register because of its lack of structural/physical integrity, separation by land modification activities from (former) adjacent agricultural developments, and lack of historic significance. A determination of ineligibility for 317 was submitted to the SHPO on August 25, 1994. SHPO concurred the site was not eligible for the National Register on September 2, 1994.

\section{McGee Ranch/Cold Creek Valley District}

Thirty-four prehistoric and historic sites were included within this request for determination of eligibility. Prehistoric sites were small but were considered to be important within a regional context because they represent an interior hunting adaptation or land use. This is significant because of a general dearth of sites representing interior land use across the Hanford Site. The majority of previously recorded interior sites tended to be associated with rocky outcrops. These lithic scatters, situated within the shrubsteppe far from permanent water, indicate use of a broader resource base. At least one of the sites dates to between 4000-3500 years ago, a period designated as the Frenchman Phase (Nelson 1969). Climatic change during this period altered the riverine environment, resulting in a disruption of previously stable adaptive strategies (Chatters 1989). Environmentally, this period was colder and wetter than previous and subsequent times.

Although many of the historic homestead/farmstead sites have been seriously disturbed, the $\mathrm{McGee}$ Ranch/Cold Creek Valley District is a relatively intact representation of early farming and ranching 
ventures in the Columbia Basin, including homesteads, furrowed fields, fence lines, irrigation systems, and trash concentrations. This area is unique in the region for use and reliance on artesian wells. Elsewhere in the region irrigation was being developed by many of these were large-scale ventures (e.g., Yakima Irrigation Company, Hanford Irrigation and Power Company, Priest Rapids Irrigation Company). Private irrigation systems from wells were developed along the Columbia River in the Pasco Basin but the extent of these systems is not well documented. New information in our understanding of the agricultural development/irrigation history of the area and lifestyles of these early farm/ranch families may be obtained from the study of the archaeological remains. Additionally, study of the semi-subterranean complexes may also yield new information on the lifestyle of individuals during the Great Depression. Within the context of the NHPA, this district would qualify for listing in the National Register under criterion $\mathrm{A}$, association with events that have made a significant contribution to the broad patterns of our history, and $\mathrm{D}$, that may be likely to yield information important in history or prehistory.

A determination form for this district was submitted to the SHPO on October 24, 1994. The SHPO concurred on November 23, 1994, that this district was eligible for listing in the National Register citing "a stronger case may be made for the district's eligibility under National Register criteria $\mathrm{C}$ and D...[because] the district's historic component more clearly derives its significance from the irrigation systems constructed on the various homesteads" (G.A. Griffith letter to R.S. Holt dated November 23, 1994).

\section{$\underline{3-121}$}

The White Bluffs Road is considered to be eligible for listing in the National Register because it was "associated with events that have made a significant contribution to the broad patterns of our history" (Criterion
A, 36 CFR Part 60.4). It was an important transportation route during the settlement, mining, and cattle eras in the Washington Territory. Evidence also suggests that within the Hanford Site boundaries, the White Bluffs Road was a major Indian trail for an unknown period prior to the arrival of the first Euroamerican settlers to the region (Rice 1984). Within the Hanford Site, the road connected an important inland water source, Rattlesnake Springs, with a commonly used ford across the Columbia River at White Bluffs. Off site, the road continued north to Fort Colville and British Columbia. The' road also extended past the southern Site boundary to Sunnyside, Yakima, and The Dalles, Oregon. Portions of the road have been irreversibly changed as industrial developments grew on the Hanford Site. These portions were considered to be non-contributing segments in terms of National Register eligibility.

A determination of eligibility for the White Bluffs Road was submitted to the SHPO in 1993. The SHPO concurred in 1994 that this site was eligible although certain segments were "non-contributing based upon significant loss of integrity" (G.A. Griffith letter to C. Pasternak dated January 6, 1994).

\section{Multiple Property Documentation Form}

The National Register Multiple Property Documentation Form (NPS 100-900-b) serves as a basis for evaluating the National Register eligibility of related properties. The themes, trends, and patterns of history shared by similar properties are organized into historic contexts, and the property types that represent those historic contexts are defined.

A draft historic context for the Manhattan Project era at Hanford was completed in FY 1994. The context describes the major events and themes associated with the establishment of the Hanford Site in December 1942 and its development through December 1946 when the Atomic Energy Commission took over operations at Hanford. 


\subsection{Properties and Isolates}

The HCRL added several properties and isolates to the Hanford Site database during FY 1994. The totals are summarized in Table 3.1. For more information, see Appendix E.

Historic American Engineering Record (HAER) documentation was initiated to mitigate proposed demolition of three National Register eligible properties - Buildings 232-Z, 233-S, and the 190-D complex. At the end of FY 1994, the Hanford Site database included 521 sites and 213 isolates.

Table 3.1 Properties and Isolates Added to Hanford Site Database in FY 1994

\begin{tabular}{ll} 
Property/Isolate & Number Added \\
\hline Non Structural Sites & 41 \\
Historic & 27 \\
Prehistoric & 11 \\
Historic / Prehistoric & 2 \\
Unknown & 1 \\
Isolated Finds & 43 \\
Historic & 16 \\
Prehistoric & 19 \\
Unknown & 8 \\
Buildings / Structures & 58
\end{tabular}

\subsection{Programmatic Agreement}

Preparation of two programmatic agreements (PA), one dealing with the built environment and a second dealing with the archaeological record, continued throughout the year. By the end of FY 1994, a draft on the structural PA was completed and reviewed by Site contractors, DOE-RL, and the Washington SHPO. 



\subsection{Archaeological Resources Protection Act Reviews}

In addition to monitoring sites discussed in Section 3.0, HCRL staff, accompanied by personnel from DOE-RL and the Wanapum Tribe, conducted a 1 day river trip of the Hanford Reach in July. Several archaeological sites along the river shore and on islands were visited to inspect present condition and effects of impacts resulting from both natural erosion and human intrusion. The trip was conducted as part of ARPA review activities. 



\subsection{American Indian Religious Freedom Act and Native American Grave Protection and Repatriation Act Compliance}

The HCRL's cultural resources project activities under this subtask fell into three categories: acquisition and curation of cultural materials; preparation of a required NAGPRA report; and discovery of human remains at the EMSL construction site in April 1994.

In November 1993, HCRL prepared an inventory of collections held at the Laboratory for DOE. The Richland Operations Office used this information to prepare a summary report of holdings to the Secretary of the Interior and affected Indian Tribes, as required by NAGPRA.

The inadvertent discovery of human remains at the EMSL construction site in April resulted in a major NAGPRA issue. HCRL personnel conducted various studies associated with relocating EMSL to a new site. 
,

$\therefore$

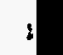




\subsection{Data Management}

One of the HCRL's significant accomplishments during FY 1994 was establishing an automated sitewide cultural resources database. Staff designed a database structure to facilitate HCRL activities. The structure was then placed into a relational database management system, and all existing data for cultural resources reviews, projects, and site forms were entered into the system. Site and project files in paper form also were maintained. 



\subsection{Curation}

In FY 1994, HCRL staff established a curation room in the Sigma V Building. Roll-out space saver shelving and a new security system were installed. DOE-RL's collections were relocated to this room. Additional boxes of artifacts were located and retrieved, which completed inventories of various site collections already in the Laboratory's care. Locating these final boxes completed the retrieval of the collections housed by members of the Mid-Columbia Archaeological Society. All collections taken from the Hanford Site and held by the University of Idaho were returned to the HCRL.
Artifacts from test units at 45BN446 and 45BN163 carried out by HCRL have been invèntoried. Dallas Van Horn, a teacher participating in DOE's summer Teacher Research Associates Program, assisted in stabilizing and identifying faunal material included in the 45BN157 collection. Mr. Van Horn has extensive training in forensic identification and was a valuable asset during his summer assignment. 



\subsection{Public Education}

Educating the general public, Hanford workers, and non-Hanford professionals is a key part of the Cultural Resources Project. The ARPA mandates dissemination of information about archaeology to instill in individuals the importance of archaeological and historic resources. Successful enforcement of that law also requires that violators be aware of the illegality of their actions. ARPA also specifies that results of archaeological studies on public lands be disseminated for use in scientific research by other professionals. In addition to legal mandates, DOE-RL wishes to publicize its activities. Also, the Laboratory is actively involved in science education programs, providing hands-on research opportunities for high school, college, and graduate-level interns.

To fulfill its legal responsibilities and contribute to DOE's educational program, the HCRL 1) makes public presentations to organizations and schools, 2) involves student interns and teachers in its work, and 3) publishes and presents scientific findings to fellow professionals.

\subsection{Public Education}

The HCRL public education activities in FY 1994 consisted of making five presentations to organizations and participating in one interview for a newspaper article. Target audiences were the Hanford workforce and the public at large. Staff also developed a traveling display consisting of several freestand- ing panels depicting the Hanford Site's history and resource protection needs. Four panels cover archaeology, Native American, Euroamerican, and Atomic eras. The display was partially developed in FY 1993. During FY 1994, the display was revisited and reviewed for completeness and accuracy.

\subsection{Interns}

The DOE funds a variety of programs for providing direct student and professional involvement in research at the Hanford Site. In FY 1994 three stu- dents interned with the HCRL through Associated Western Universities (AWU). These students participated in HCRL field and laboratory work. 



\subsection{References}

Bard, James C, R. McClintock, and J. B. Cox. 1994. A Cultural Resources Inventory of Proposed Basalt Quarry Sites at the Department of Energy's Hanford Site, Benton County, Washington. Contractor report for Pacific Northwest Laboratory.

Chatters; J.C. 1982. "Prehistoric Settlement and Land Use in the Dry Columbia Basin." Northwest Anthropol. Res. Notes 16:125-147.

Chatters, J.C. 1989. Hanford Cultural Resources Management Plan. PNL-6942, Pacific Northwest Laboratory, Richland, Washington.

Chatters, J. C., N. A. Cadoret, and P. E. Minthorn. 1990. Hanford Cultural Resources Laboratory Annual Report for Fiscal Year 1989. PNL-7362, Pacific Northwest Laboratory, Richland, Washington.

Chatters, J. C., H. A. Gard, and P. E. Minthorn. 1991. Hanford Cultural Resources Laboratory Annual Report for Fiscal Year 1990. PNL-7853, Pacific Northwest Laboratory, Richland, Washington.

Chatters, J. C., H. A. Gard, and P. E. Minthorn. 1992. Hanford Cultural Resources Laboratory Annual Report for Fiscal Year 1991. PNL-8101, Pacific Northwest Laboratory, Richland, Washington.

Chatters, J. C., H. A. Gard, M. K. Wright, M. E. Crist, J. G. Longenecker, T. K. O'Neil, and M. V. Dawson. 1993. Hanford Cultural Resources Laboratory Annual Report for Fiscal Year 1992. PNL-8676, Pacific Northwest Laboratory, Richland, Washington.

Daugherty, R. D. 1952. "Archaeological Investigations of O'Sullivan Reservoir, Grant County, Washington." American Antiquity. 17:274-278.

Green, G. S. 1975. Prehistoric Utilization of the Channeled Scablands of Eastern Washington. Ph.D. Dissertation, Department of Anthropology, Washington State University, Pullman, Washington.

Greengo, R. E. 1982. Studies in Prehistory: Priest Rapids and Wanapum Reservoir Areas, Columbia River, Washington. Department of Anthropology, University of Washington, Seattle, Washington. 
Last, G. V., M. K. Wright, M. E. Crist, N. A. Cadoret, M. V. Dawson, K. A. Simmons, D. W. Harvey, J. G. Longenecker. 1994. Hanford Cultural Resources Laboratory Annual Report for Fiscal Year 1993. PNL-10077, Pacific Northwest Laboratory, Richland, Washington.

Leonhardy, F. C. and D. G. Rice. 1970. "A Proposed Cultural Typology for the Lower Snake River Region, Southeastern, Washington." Northwest Anthropological Research Notes 4(1):1-29.

Nelson, C. M. 1969. The Sunset Creek Site (45KT28) and its Place in Plateau Prehistory. Anthropology Report of Investigations No. 47, Washington State University, Pullman, Washington.

Parker, P. L., T. F. King. n.d. Guidelines for Evaluating and Documenting Traditional Cultural Properties. National Register Bulletin 38. U.S. Department of the Interior. National Park Service, Washington, D.C.

Relander, C. 1956. Drummers and Dreamers. Caxton Printers, Caldwell, Idaho.

Rice, D. G. 1968a. Archeological Reconnaissance: Ben Franklin Reservoir Area, 1968. Washington State University, Laboratory of Anthropology, Pullman, Washington.

Rice, D. G. 1968b. Archeological Reconnaissance: Hanford Atomic Works. National Park Service, U. S. Atomic Energy Commission. Washington State University, Pullman, Washington.

Rice, D. G. 1980. Overview of Cultural Resources on the Hanford Reservation in South Central Washington State. Report submitted to U.S. Department of Energy, Richland, Washington.

Spier, L. 1936. Tribal Distribution in Washington. General Services in Anthropology No. 3, George Banta Publishing Co., Menasha, Wisconsin.

Trafzer, C. E., and R. D. Scheuerman. 1986. Renegade Tribe: The Palouse Indians and the Invasion of the Inland Pacific Northwest. Washington State University Press, Pullman, Washington. 
Appendix A 

APPENDIX A. Section 106 Reviews Conducted in FY 1994

\begin{tabular}{|c|c|c|c|c|c|}
\hline $\begin{array}{l}\text { Case } \\
\text { Number }\end{array}$ & Project Name & Class & $\begin{array}{c}\text { Date } \\
\text { Received }\end{array}$ & $\begin{array}{c}\text { Date } \\
\text { Completed }\end{array}$ & $\begin{array}{l}\text { Requesting } \\
\text { Organization }\end{array}$ \\
\hline $93-300-063$ & L-186, Hanford Site Entry Control Center & $\mathrm{V}$ & $8 / 27 / 93$ & $9 / 14 / 93$ & WHC \\
\hline 94-000-001 & GTE Telephone NW Telecom. Line & III & $1 / 6 / 94$ & $1 / 10 / 94$ & DOE \\
\hline 94-000-002 & Cascade Natural Gas & III & $4 / 26 / 94$ & $4 / 27 / 94$ & DOE \\
\hline $94-100-001$ & Replace Fire Hydrant F-2 & 1 & $10 / 7 / 93$ & $10 / 11 / 93$ & WHC \\
\hline $94-100-002$ & Tank Removal at 184-DA & III & $10 / 15 / 93$ & $10 / 20 / 93$ & WHC \\
\hline $94-100-003$ & Tank Removal at $184-\mathrm{N}$ & III & $10 / 15 / 93$ & $10 / 20 / 93$ & WHC \\
\hline $94-100-004$ & $\begin{array}{l}\text { Post Indicator Valve \#14 next to } 184 \mathrm{~N} \\
\text { Leaks }\end{array}$ & 1 & $10 / 19 / 93$ & $10 / 20 / 93$ & WHC. \\
\hline 94-100-005 & Water Isolations at 190-D & 1 & $10 / 28 / 93$ & $11 / 1 / 93$ & WHC \\
\hline $94-100-006$ & $1721 \mathrm{~K}$ Transformer Upgrade & III & $10 / 28 / 93$ & $11 / 3 / 93$ & WHC \\
\hline $94-100-007$ & 128-H-1 Burn Pit Soil-Gas Survey & III & $11 / 4 / 93$ & $11 / 8 / 93$ & WHC \\
\hline $94-100-008$ & Extension of Rad Waste Pad & III & $11 / 15 / 93$ & $11 / 22 / 93$ & WHC \\
\hline 94-100-009 & Effluent Pipe ERA & 1 & $11 / 22 / 93$ & $12 / 10 / 93$ & WHC \\
\hline $94-100-010$ & $\begin{array}{l}\text { Excavate \& Repair Fire Water Piping } \\
\text { around PIV } 82\end{array}$ & 1 & $12 / 1 / 93$ & $12 / 1 / 93$ & WHC \\
\hline $94-100-011$ & $\begin{array}{l}\text { Continuous Air Monitor Installations at } \\
105 \mathrm{KE}\end{array}$ & III & $11 / 29 / 93$ & $12 / 2 / 93$ & WHC \\
\hline $94-100-012$ & N Reactor Stabilization & III & $12 / 13 / 93$ & $1 / 4 / 94$ & WHC \\
\hline $94-100-013$ & K West Field Storage Basin & III & $12 / 10 / 93$ & $12 / 14 / 93$ & WHC \\
\hline \begin{tabular}{|l|}
$94-100-$ \\
$014 A$ \\
\end{tabular} & 105KE/KW Security Upgrades & $\mathrm{VI}$ & $12 / 21 / 93$ & $1 / 21 / 94$ & WHC \\
\hline $\begin{array}{l}94-100- \\
014 B\end{array}$ & 105KE/KW Seismic Upgrades & V! & $12 / 21 / 93$ & $3 / 21 / 94$ & WHC \\
\hline $94-100-015$ & $\begin{array}{l}\text { Drug Testing Facility Modifications at } \\
1135-\mathrm{N}\end{array}$ & III & $1 / 6 / 94$ & $1 / 10 / 94$ & WHC \\
\hline $94-100-016$ & $\begin{array}{l}\text { Export Water Line Drain Valve } \\
\text { Replacement }\end{array}$ & III & $1 / 14 / 94$ & $3 / 15 / 94$ & KEH \\
\hline 94-100-017 & 100F Area-Deactivate Fire Hydrants & 1 & $1 / 17 / 94$ & $1 / 19 / 94$ & WHC \\
\hline $94-100-018$ & $\begin{array}{l}\text { Surplus Production Reactor } \\
\text { Decommissioning }\end{array}$ & $\mathrm{V} / \mathrm{NI}$ & $1 / 21 / 94$ & & WHC \\
\hline $94-100-019$ & Utility Upgrades in $100 \mathrm{~N}$ & 1 & $1 / 25 / 94$ & $1 / 26 / 94$ & WHC \\
\hline $94-100-020$ & $\begin{array}{l}\text { Install Air Compressor Condensate } \\
\text { Evaporator in } 10\end{array}$ & $\mathrm{VI}$ & $1 / 26 / 94$ & $12 / 31 / 94$ & WHC \\
\hline $94-100-021$ & Security Fencing at the $1135-N$ Trailer & III & $1 / 26 / 94$ & $1 / 27 / 94$ & WHC \\
\hline $94-100-022$ & Light Pole Installation at 8 Intersections & III & $2 / 4 / 94$ & $2 / 8 / 94$ & WHC \\
\hline 94-100-023 & Guard Post at $105 \mathrm{~N}$ & III & $2 / 7 / 94$ & $2 / 8 / 94$ & WHC \\
\hline $94-100-024$ & $\begin{array}{l}\text { E-027, Reconfigure 230KV Transmission } \\
\text { System }\end{array}$ & V & $2 / 14 / 94$ & & WHC \\
\hline $94-100-025$ & In-Situ Redox Manipulation - 100 D & Iil & $2 / 14 / 94$ & $2 / 16 / 94$ & PNL \\
\hline
\end{tabular}




\begin{tabular}{|c|c|c|c|c|c|}
\hline $\begin{array}{l}\text { Case } \\
\text { Number }\end{array}$ & Project Name & Class & $\begin{array}{c}\text { Date } \\
\text { Received } \\
\end{array}$ & $\begin{array}{c}\text { Date } \\
\text { Completed } \\
\end{array}$ & $\begin{array}{l}\text { Requesting } \\
\text { Organization }\end{array}$ \\
\hline $\begin{array}{l}94-100- \\
025 \mathrm{~A}\end{array}$ & In-Situ Redox Manipulation - $100 \mathrm{H}$ & IIII & $5 / 24 / 94$ & $6 / 9 / 94$ & PNL \\
\hline $94-100-026$ & IVDTS Fiber to $100 \mathrm{~B} / \mathrm{C}$ & III & $2 / 15 / 94$ & $3 / 17 / 94$ & WHC \\
\hline $94-100-027$ & In Situ Permeable Flow Sensor Installation & III & $2 / 22 / 94$ & $3 / 11 / 94$ & WHC \\
\hline $94-100-028$ & 100-HR-3 Groundwater Remediation & III & $2 / 24 / 94$ & $2 / 28 / 94$ & WHC \\
\hline $94-100-029$ & $\begin{array}{l}\text { Test Pit Investigation/100-N-SS-28 } \\
\text { Underground }\end{array}$ & ill & $3 / 14 / 94$ & $3 / 16 / 94$ & WHC \\
\hline $94-100-030$ & 105B Front Face Carpet Installation & $\mathrm{VI}$ & $3 / 22 / 94$ & $3 / 23 / 94$ & WHC \\
\hline $94-100-031$ & Shutdown 183-D Water Filter Plant & 1 & $3 / 28 / 94$ & $3 / 31 / 94$ & $\mathrm{KEH}$ \\
\hline $94-100-032$ & Demolition of $183-\mathrm{C}$ and $190-\mathrm{C}$ & VI & $10 / 4 / 94$ & $10 / 20 / 94$ & WHC \\
\hline $94-100-033$ & 118-B-1 Burial Ground Treatability Study & III & $4 / 1 / 94$ & $4 / 5 / 94$ & WHC \\
\hline $94-100-035$ & K-Pools for Salmon Rearing & IV & $4 / 19 / 94$ & & WHC \\
\hline $94-100-036$ & Repair Water Valve by $183-D$ & 1 & $4 / 19 / 94$ & $4 / 20 / 94$ & $\mathrm{KEH}$ \\
\hline $94-100-037$ & Fuel Basin Door Replacement in $100 \mathrm{H}$ & III & $5 / 3 / 94$ & & WHC \\
\hline 94-100-038 & 1713-H Warehouse Demolition & VI & $5 / 11 / 94$ & & WHC \\
\hline 94-100-039 & 100 Areas Trailer Relocation & III & $5 / 16 / 94$ & $5 / 20 / 94$ & WHC \\
\hline $94-100-040$ & K Basin Seismic Leak Response Actions & IVNI & $5 / 18 / 94$ & $5 / 23 / 94$ & WHC \\
\hline $94-100-041$ & Slurry Walls at $100 \mathrm{D}$ and $100 \mathrm{H}$ & IV & $5 / 18 / 94$ & & $\pi$. \\
\hline $94-100-042$ & $\begin{array}{l}\text { 105-B Leak Repair \& Air Conditioner } \\
\text { Installation }\end{array}$ & $\mathrm{VI}$ & $6 / 3 / 94$ & $6 / 10 / 94$ & WHC \\
\hline $94-100-043$ & Vortec Phase III Field Demonstration & III & $6 / 7 / 94$ & $6 / 15 / 94$ & WHC \\
\hline $94-100-044$ & $\begin{array}{l}\text { Design \& Construct Enclosed Change } \\
\text { Rm \& Expand Fire Sprinkler System 182- } \\
\text { B }\end{array}$ & $\mathrm{VI}$ & $6 / 9 / 94$ & $6 / 22 / 94$ & KEH \\
\hline $94-100-045$ & $\begin{array}{l}\text { K Area 90-Day RCRA Waste Storage } \\
\text { Facility }\end{array}$ & III & $6 / 6 / 94$ & $6 / 10 / 94$ & WHC \\
\hline $94-100-046$ & N Springs Area Projects & IV & $5 / 16 / 94$ & & WHC \\
\hline $94-100-047$ & $\begin{array}{l}\text { Repairs near } 105 \mathrm{H}, 183 \mathrm{H} \\
\text { Clearwells, 100F Export Line, 151-D }\end{array}$ & 1 & $6 / 15 / 94$ & $6 / 21 / 94$ & KEH \\
\hline $94-100-048$ & Post Holes at $100 \mathrm{KW}$ & III & $6 / 16 / 94$ & $6 / 21 / 94$ & WHC \\
\hline $94-100-049$ & 107 N Washout & $\mathbb{1}$ & $6 / 20 / 94$ & $7 / 18 / 94$ & WHC \\
\hline $94-100-050$ & 105-B Roof Panel Support Installation & VI & $7 / 1 / 94$ & $7 / 20 / 94$ & WHC \\
\hline $94-100-051$ & $\begin{array}{l}\text { 105KE Basin Spent Nuclear Fuel/Sludge } \\
\text { Pilot Run }\end{array}$ & $\mathrm{VI}$ & $7 / 8 / 94$ & $7 / 20 / 94$ & WHC \\
\hline $94-100-052$ & HLAN/Phone Expansion to 183KE & III & $7 / 25 / 94$ & $7 / 29 / 94$ & WHC \\
\hline $94-100-053$ & 100K Area Systems \& Facilities Upgrades & 1 & $7 / 29 / 94$ & $8 / 10 / 94$ & WHC \\
\hline $94-100-054$ & Excavation at 105-C Reactor & 1 & $8 / 10 / 94$ & $8 / 15 / 94$ & WHC \\
\hline $94-100-055$ & N-Deactivation Small Building Demolition & $\mathrm{VI}$ & $8 / 19 / 94$ & & $\mathrm{CHI}$ \\
\hline $94-100-056$ & 116H3 Remedial Action & 1 & $8 / 26 / 94$ & $9 / 16 / 94$ & $\mathrm{CHI}$ \\
\hline $94-100-057$ & 116B9 and10 Removal Action & 1 & $8 / 26 / 94$ & $9 / 16 / 94$ & $\mathrm{CHI}$ \\
\hline $94-100-058$ & 116-D-3 \& D-4 Removal Action & 1 & $8 / 26 / 94$ & $9 / 16 / 94$ & $\mathrm{CHI}$. \\
\hline
\end{tabular}




\begin{tabular}{|c|c|c|c|c|c|}
\hline $\begin{array}{c}\text { Case } \\
\text { Number }\end{array}$ & Project Name & Class & $\begin{array}{c}\text { Date } \\
\text { Received }\end{array}$ & $\begin{array}{c}\text { Date } \\
\text { Completed } \\
\end{array}$ & $\begin{array}{l}\text { Requesting } \\
\text { Organization }\end{array}$ \\
\hline $94-100-059$ & Riverland ERA & 1 & $9 / 12 / 94$ & $9 / 20 / 94$ & $\mathrm{CH} 2 \mathrm{MH}$ \\
\hline $94-100-060$ & Riser Installation Test and Simulation & 1 & $9 / 20 / 94$ & $9 / 23 / 94$ & WHC \\
\hline $94-200-001$ & $\begin{array}{l}\text { Interim Stabiliz. of 216-T-4-1 Pond \& 216- } \\
\text { U-8/UN-216-W-41 }\end{array}$ & III & $10 / 1 / 93$ & $10 / 4 / 93$ & WHC \\
\hline $94-200-002$ & $\begin{array}{l}\text { 2724-W, 2724-WA, 2724-WB BIdg } \\
\text { Demolitions }\end{array}$ & VI & $10 / 4 / 93$ & & WHC \\
\hline 94-200-003 & Pressure Vacuum Breaker & 1 & $10 / 4 / 93$ & $10 / 5 / 93$ & WHC \\
\hline $94-200-004$ & Gate 814 Install Sign \#2K-93-601M & III & $10 / 6 / 93$ & $10 / 6 / 93$ & WHC \\
\hline 94-200-005 & Relocate Trailer MO857 & III & $10 / 12 / 93$ & $10 / 13 / 93$ & $\mathrm{KEH}$ \\
\hline $94-200-006$ & $\begin{array}{l}\text { Water Line Tap \& Decontamination of } \\
\text { 216-B-57 Contamination Spread }\end{array}$ & III & $10 / 13 / 93$ & $10 / 13 / 93$ & WHC \\
\hline $94-200-007$ & 2715EC Water Service Replacement & 1 & $10 / 14 / 93$ & $10 / 14 / 93$ & WHC \\
\hline $94-200-008$ & $\begin{array}{l}\text { Install By-Pass Blowdown 242-S Bldg } \\
\text { Steam }\end{array}$ & III & $10 / 14 / 93$ & $10 / 18 / 93$ & WHC \\
\hline $94-200-009$ & 241-TX J-Box Alignment & III & $10 / 20 / 93$ & $10 / 21 / 93$ & WHC \\
\hline $9,4-200-010$ & Misc. 200A CWO's & III & $10 / 21 / 93$ & $10 / 26 / 93$ & WHC \\
\hline $94-200-011$ & $\begin{array}{l}\text { 202A Hydrant 2A/114S Leaking } \\
\text { Underground }\end{array}$ & 1 & $10 / 21 / 93$ & $10 / 22 / 93$ & WHC \\
\hline 94-200-012 & 2706-T Facility Concrete Pad Shelter & III & $10 / 21 / 93$ & $10 / 25 / 93$ & WHC \\
\hline $94-200-013$ & 241-SY Addition of J-Box Supports & 1 & $10 / 26 / 93$ & $10 / 28 / 93$ & WHC \\
\hline $94-200-014$ & Replace Steam Valve & 1 & $10 / 27 / 93$ & $11 / 2 / 93$ & WHC \\
\hline $94-200-015$ & $\begin{array}{l}\text { Replace } 3 \text { Underground Steamline at } \\
2719-W A \text { Bldg }\end{array}$ & 1 & $10 / 28 / 93$ & $10 / 28 / 93$ & WHC \\
\hline 94-200-016 & L-100-2711E Shop & III & $10 / 28 / 93$ & $11 / 3 / 93$ & WHC \\
\hline $94-200-017$ & 241-SX Heat Trace Pull Boxes & III & $10 / 28 / 93$ & $11 / 3 / 93$ & WHC \\
\hline $94-200-018$ & Geologic Testing of Mixed Waste Trench & III & $11 / 1 / 93$ & $11 / 3 / 93$ & WHC \\
\hline 94-200-019 & T-Plant Security Fence & III & $11 / 2 / 93$ & $11 / 3 / 93$ & WHC \\
\hline 94-200-020 & Steam Line Repairs & 1 & $11 / 3 / 93$ & $11 / 4 / 93$ & $\mathrm{KEH}$ \\
\hline 94-200-021 & 241-SY Install Wires in Conduit & III & $11 / 8 / 93$ & $11 / 10 / 93$ & WHC \\
\hline $94-200-022$ & $\begin{array}{l}\text { Akron/4th St Telecommunications } \\
\text { Upgrade for Service to HWVP }\end{array}$ & III & $11 / 5 / 93$ & $11 / 10 / 93$ & -WHC \\
\hline $94-200-023$ & $\begin{array}{l}\text { Excavate French Drain at } 283 W \text { Filter } \\
\text { Building }\end{array}$ & 1 & $11 / 8 / 93$ & $11 / 10 / 93$ & WHC \\
\hline $94-200-024$ & $\begin{array}{l}\text { Repair Condensate Line to Sewer at } \\
283 \mathrm{~W}\end{array}$ & $\mathrm{~T}$ & $11 / 8 / 93$ & $11 / 10 / 93$ & WHC \\
\hline $94-200-025$ & 277W Condensate Line & 1 & $11 / 16 / 93$ & $11 / 18 / 93$ & WHC \\
\hline $94-200-026$ & Repair Cable Adjacent to Baltimore Ave. & 1 & $11 / 10 / 93$ & $11 / 15 / 93$ & WHC \\
\hline $94-200-027$ & 2750E and Adjacent Facilities Drainfiéld & III & $11 / 11 / 93$ & $11 / 12 / 93$ & WHC \\
\hline $94-200-028$ & $\begin{array}{l}\text { Install Conduit fr. 102-AY Pit 02D to 241- } \\
\text { AT-801 }\end{array}$ & III & $11 / 11 / 93$ & $11 / 15 / 93$ & WHC \\
\hline $94-200-029$ & $\begin{array}{l}\text { 241-T Add Photo Cell \& Lighting } \\
\text { Contractor }\end{array}$ & III & $11 / 12 / 93$ & $11 / 15 / 93$ & WHC \\
\hline $94-200-030$ & 241-AN Farm HVAC & III & $11 / 15 / 93$ & $11 / 18 / 93$ & WHC \\
\hline
\end{tabular}




\begin{tabular}{|c|c|c|c|c|c|}
\hline $\begin{array}{l}\text { Case } \\
\text { Number }\end{array}$ & Project Name & Class & $\begin{array}{c}\text { Date } \\
\text { Received }\end{array}$ & \begin{tabular}{c|} 
Date \\
Completed \\
\end{tabular} & $\begin{array}{l}\text { Requesting } \\
\text { Organization }\end{array}$ \\
\hline $94-200-031$ & $\begin{array}{l}\text { Repair Water Line Leak by } 202 S \text { Plant- } \\
200 \mathrm{~W}\end{array}$ & 1 & $11 / 16 / 93$ & $11 / 16 / 93$ & WHC \\
\hline $94-200-032$ & $\begin{array}{l}\text { W-312 -Storage Pad South of Central } \\
\text { Waste Complex }\end{array}$ & III & $11 / 16 / 93$ & $11 / 17 / 93$ & WHC \\
\hline $94-200-033$ & $\begin{array}{l}\text { Electric Power to } 2 \text { New Low Level Conex } \\
\text { Boxes }\end{array}$ & III & $11 / 1 / 93$ & $11 / 18 / 93$ & WHC \\
\hline $94-200-034$ & C-077, T-Plant HVAC Upgrade & $\mathrm{VI}$ & $11 / 22 / 93$ & $12 / 2 / 93$ & WHC \\
\hline $94-200-035$ & $\begin{array}{l}\text { W-259, T-Plant 2ndary Containment \& } \\
\text { Leak Detection }\end{array}$ & III & $11 / 22 / 93$ & $12 / 2 / 93$ & WHC \\
\hline $94-200-036$ & Repair Water Line Leak Beside MO-252 & 1 & $11 / 24 / 93$ & $11 / 24 / 93$ & WHC \\
\hline $94-200-037$ & $\begin{array}{l}\text { 241-SX Replace Cables on Sludge } \\
\text { Cooler }\end{array}$ & III & $11 / 17 / 93$ & $11 / 24 / 93$ & WHC \\
\hline $94-200-038$ & 2607-WC Drainfield Replacement & 1 & $11 / 24 / 93$ & $11 / 30 / 93$ & WHC \\
\hline $94-200-039$ & $\begin{array}{l}\text { Long-Length Waste Equipment Transfer } \\
\text { Port Addition Project }\end{array}$ & III & $11 / 22 / 93$ & $12 / 1 / 93$ & WHC \\
\hline $94-200-040$ & 2720W/2709W Replace Sewer Line & $\mathrm{I}$ & $11 / 22 / 93$ & $11 / 29 / 93$ & WHC \\
\hline $94-200-041$ & $\begin{array}{l}\text { Replace } 4 \text { Below Grade Steamline at } \\
272 W\end{array}$ & 1 & $11 / 22 / 93$ & $11 / 29 / 93$ & WHC \\
\hline 94-200-042 & Installation of Heat Trace Circuits & III & $11 / 22 / 93$ & $11 / 30 / 93$ & WHC \\
\hline $94-200-043$ & Installation of Fence at 2312 & III & $11 / 29 / 93$ & $11 / 29 / 93$ & WHC \\
\hline $94-200-044$ & Area Radialion Repair & III & $11 / 29 / 93$ & $11 / 29 / 93$ & WHC \\
\hline $94-200-045$ & $\begin{array}{l}\text { 244-TX Label Disconnect SW \& } \\
\text { Grounding. }\end{array}$ & III & $11 / 30 / 93$ & $12 / 1 / 93$ & WHC \\
\hline 94-200-046 & Thermocouple Flex Removal & 1 & $12 / 2 / 93$ & $12 / 2 / 93$ & WHC \\
\hline 94-200-047 & 2K-92-466 2713-W Chemical Storage & III & $11 / 30 / 93$ & $12 / 7 / 93$ & WHC \\
\hline $94-200-048$ & $\begin{array}{l}\text { Ground Floodlight Poles in 241-TX, TY, } \\
241-S-S X\end{array}$ & III & $11 / 30 / 93$ & $12 / 6 / 93$ & WHC \\
\hline 94-200-049 & Repair Water Line Leak by Valve 135-S & 1 & $11 / 30 / 93$ & $12 / 6 / 93$ & WHC \\
\hline 94-200-050. & Repair Water Valve near $2101-\mathrm{M}$ & 1 & $12 / 2 / 93$ & $12 / 6 / 93$ & WHC \\
\hline $94-200-051$ & Replace Underground Cable at 244-TX & 1 & $12 / 6 / 93$ & $12 / 7 / 93$ & WHC \\
\hline 94-200-052 & $200-U P-1$ & III & $12 / 3 / 93$ & $12 / 13 / 93$ & WHC \\
\hline 94-200-053 & Carbon Tetrachloride Vapor Extraction & III & $12 / 9 / 93$ & $12 / 16 / 93$ & WHC \\
\hline 94-200-054 & 241T Move Lit to Riser \#8 from Riser \#1 & III & & $12 / 14 / 93$ & WHC \\
\hline $94-200-055$ & T-Plant 10-Wide Mobile Office & III & $12 / 10 / 93$ & $12 / 15 / 93$ & WHC \\
\hline $94-200-056$ & $\begin{array}{l}\text { T-Plant Mixed Waste Container Storage } \\
\text { Building }\end{array}$ & III & $12 / 10 / 93$ & $12 / 15 / 93$ & WHC \\
\hline 94-200-057 & 200E Mobile Offices \& 2750 Upgrades & $\mathrm{VI}$ & $12 / 15 / 93$ & $12 / 17 / 93$ & WHC \\
\hline $94-200-058$ & 200-UP-1, 200-ZP-1 & III & $12 / 20 / 93$ & $12 / 21 / 93$ & WHC \\
\hline 94-200-059 & Replace Condensate Line at 2713-E & 1 & $12 / 21 / 93$ & $12 / 21 / 93$ & WHC \\
\hline $94-200-060$ & Inspect Heat Trace on Exhausters & 1 & $12 / 22 / 93$ & $12 / 22 / 93$ & WHC \\
\hline 94-200-061 & Tank Farm Ventilation Upgrade & III & $12 / 20 / 93$ & $12 / 21 / 93$ & WHC \\
\hline 94-200-062 & MO-268 Water Line Leak & $\mathrm{I}$ & $12 / 29 / 93$ & $12 / 29 / 93$ & WHC \\
\hline 94-200-063 & Conex Box 'for Bldg 2715EA & III & $12 / 28 / 93$ & $1 / 3 / 94$ & WHC \\
\hline
\end{tabular}




\begin{tabular}{|c|c|c|c|c|c|}
\hline $\begin{array}{l}\text { Case } \\
\text { Number }\end{array}$ & Project Name & Class & $\begin{array}{c}\text { Date } \\
\text { Received }\end{array}$ & $\begin{array}{c}\text { Date } \\
\text { Completed } \\
\end{array}$ & $\begin{array}{l}\text { Requesting } \\
\text { Organization } \\
\end{array}$ \\
\hline $94-200-064$ & $\begin{array}{l}\text { Install Colling Tower Water, Bleed Line, } \\
2750 E-D \text { W }\end{array}$ & [II] & $1 / 5 / 94$ & $1 / 5 / 94$ & WHC \\
\hline $94-200-065$ & Small Projects in 200 \& 300 Areas & III & $1 / 5 / 94$ & $11 / 17 / 11$ & WHC \\
\hline $94-200-066$ & W-200, Initial Tank Retrieval Systems & III & $1 / 5 / 94$ & $1 / 10 / 94$ & WHC \\
\hline 94-200-067 & Surface Barrier & III & $1 / 5 / 94$ & $1 / 12 / 94$ & WHC \\
\hline $94-200-068$ & $\begin{array}{l}\text { 200/Solid Waste/Central Waste Complex } \\
\text { Facility }\end{array}$ & III & $1 / 10 / 94$ & $1 / 11 / 94$ & WHC \\
\hline $94-200-069$ & 2 Trenches near 241-B-701 & III & $1 / 13 / 94$ & $1 / 17 / 94$ & WHC \\
\hline 94-200-070 & Equipment Steamcleaning Pad & III & $1 / 13 / 94$ & $1 / 17 / 94$ & KEH \\
\hline $94-200-071$ & W-363, 209E Septic System Upgrade & III & $1 / 14 / 94$ & $1 / 19 / 94$ & WHC \\
\hline $94-200-072$ & Replace Condensate Line at 2707-E & 1 & $1 / 17 / 94$ & $1 / 19 / 94$ & WHC \\
\hline $94-200-073$ & $\begin{array}{l}\text { Relocation and Storage of TRIGA Reactor } \\
\text { Irradiated Fuel }\end{array}$ & III & $1 / 17 / 94$ & $1 / 19 / 94$ & WHC \\
\hline $94-200-074$ & Install Light Poles at ENW Vent Station & III & $1 / 17 / 94$ & $1 / 19 / 94$ & WHC \\
\hline $94-200-075$ & Trenches near the 244-AR BIdg & III & $1 / 19 / 94$ & $1 / 21 / 94$ & WHC \\
\hline $94-200-076$ & $\begin{array}{l}\text { Akron/4th St Telecomm. Upgrades -Air } \\
\text { Monitoring Facility }\end{array}$ & VI & $1 / 20 / 94$ & $1 / 21 / 94$ & $\mathrm{KEH}$ \\
\hline $94-200-077$ & Burial Ground Increase Trench \#33 & III & $1 / 20 / 94$ & $1 / 21 / 94$ & WHC \\
\hline $94-200-078$ & $\begin{array}{l}\text { VOC-Arid ID Atmosphere CC/4 Survey \& } \\
\text { Soil Gas }\end{array}$ & III & $1 / 25 / 94$ & $1 / 26 / 94$ & WHC \\
\hline 94-200-079 & Mixer Pump 101-SY: Install Strobe Light & III & $1 / 27 / 94$ & $1 / 27 / 94$ & WHC \\
\hline $94-200-080$ & $\begin{array}{l}\text { Conduit \& Wiring in 241-AY \& 241-AZ } \\
\text { Farms }\end{array}$ & 1 & $1 / 27 / 94$ & $1 / 28 / 94$ & WHC \\
\hline $94-200-081$ & $\begin{array}{l}\text { Hanford Legacy Sodium Test Facilities } \\
\text { Removal Plan }\end{array}$ & $\mathrm{VI}$ & $1 / 27 / 94$ & $2 / 17 / 94$ & WHC \\
\hline $94-200-082$ & $\begin{array}{l}\text { Repair \#18 Cathodic Recifier (2E-93- } \\
\text { 02092/W) }\end{array}$ & 1 & $1 / 28 / 94$ & $1 / 28 / 94$ & WHC \\
\hline 94-200-083 & Replace Electrical Line in 241-A & 1 & $1 / 28 / 94$ & $1 / 31 / 94$ & WHC \\
\hline $94-200-084$ & Sign near Corner of Dayton \& 23rd & III & $1 / 31 / 94$ & $2 / 1 / 94$ & WHC \\
\hline $94-200-085$ & $\begin{array}{l}\text { Repair } 8 \text { Ash Line Leak West Side of } \\
\text { 284E }\end{array}$ & 1 & $1 / 31 / 94$ & $2 / 1 / 94$ & WHC \\
\hline $94-200-086$ & $\begin{array}{l}\text { Repair Water Line \& Valve by MO-268 \& } \\
272 \mathrm{AW}\end{array}$ & 1 & $2 / 1 / 94$ & $2 / 2 / 94$ & WHC \\
\hline $94-200-087$ & $\begin{array}{l}\text { 216-A-40 Retention Basin Interim } \\
\text { Stabilization }\end{array}$ & III & $2 / 3 / 94$ & $2 / 7 / 94$ & WHC \\
\hline $94-200-088$ & W-363, 272WA Septic Upgrades & III & $2 / 8 / 94$ & $2 / 9 / 94$ & WHC \\
\hline 94-200-089 & Repair 8 Sewer Line near Ames Ave. & 1 & $2 / 8 / 94$ & $2 / 9 / 94$ & WHC \\
\hline $94-200-090$ & W-314B Dble Shell Tank Vent Upgrd & III & $2 / 14 / 94$ & $2 / 15 / 94$ & WHC \\
\hline $94-200-091$ & 3 Posts at 274E Transformer & III & $2 / 14 / 94$ & $2 / 15 / 94$ & WHC \\
\hline $94-200-092$ & Power to CONEX Boxes near 2244-B & III & $2 / 14 / 94$ & $2 / 15 / 94$ & $\mathrm{KEH}$ \\
\hline 94-200-093 & KEH Facility ID Sign & III & $2 / 14 / 94$ & $2 / 16 / 94$ & $\mathrm{KEH}$ \\
\hline $94-200-094$ & 94G-EWW-401: Installation of MO-293 & II! & $2 / 16 / 94$ & $2 / 17 / 94$ & WHC \\
\hline $94-200-095$ & 2750-E Awards Stage & 1 & $2 / 16 / 94$ & $2 / 22 / 94$ & $\mathrm{KEH}$ \\
\hline
\end{tabular}




\begin{tabular}{|c|c|c|c|c|c|}
\hline $\begin{array}{l}\text { Case } \\
\text { Number }\end{array}$ & Project Name & Class & $\begin{array}{c}\text { Date } \\
\text { Received }\end{array}$ & $\begin{array}{c}\text { Date } \\
\text { Completed } \\
\end{array}$ & \begin{tabular}{|l|} 
Requesting \\
Organization
\end{tabular} \\
\hline $94-200-096$ & $\begin{array}{l}\text { 241-A-701 Compressed Air System } \\
\text { Replacement }\end{array}$ & 111 & $2 / 22 / 94$ & $2 / 23 / 94$ & WHC \\
\hline $94-200-097$ & $\begin{array}{l}\text { W-236A, Multi-Function Waste Tank Fac.- } \\
200 \mathrm{E}\end{array}$ & III & $2 / 22 / 94$ & $5 / 17 / 94$ & WHC \\
\hline \multirow[t]{2}{*}{ 94-200-098 } & PUREX/U03 Deactivation Project & $\mathrm{VI}$ & $2 / 25 / 94$ & $2 / 28 / 94$ & WHC \\
\hline & Heat Tracer Station Removal & III & $3 / 2 / 94$ & $3 / 2 / 94$ & WHC \\
\hline $94-200-100$ & L-207 - Trenches at MO291 & III & $3 / 3 / 94$ & $3 / 7 / 94$ & $\mathrm{KEH}$ \\
\hline $94-200-101$ & $\begin{array}{l}\text { Instrument Air Supply-Line Repair at } \\
\text { South Side of }\end{array}$ & $\mathrm{T}$ & $3 / 7 / 94$ & $3 / 8 / 94$ & WHC \\
\hline $94-200-102$ & Integrity Assessmt of SN-216 in $241-\mathrm{U}$ & 1 & $3 / 8 / 94$ & $3 / 8 / 94$ & $\mathrm{KEH}$ \\
\hline $94-200-103$ & $\begin{array}{l}\text { Relocate Oil Fired Boiler from } 384 \mathrm{E} \text { to } \\
284 \mathrm{E}\end{array}$ & III & $3 / 8 / 94$ & $3 / 11 / 94$ & KEH \\
\hline $94-200-104$ & $\begin{array}{l}211 T \text { Above Ground Bulk Chem Storg } \\
\text { Tanks }\end{array}$ & 1 & $3 / 10 / 94$ & $3 / 11 / 94$ & WHC \\
\hline 94-200-105 & 217-B Equipment and Building Removal & $\mathrm{VI}$ & $3 / 11 / 94$ & & \\
\hline 94-200-106 & W-320, Tank C-106 Sluicing & III & $3 / 14 / 94$ & $3 / 15 / 94$ & WHC \\
\hline $94-200-107$ & Routine Restoration & III & $3 / 16 / 94$ & $3 / 18 / 94$ & WHC \\
\hline $94-200-108$ & Install Cranes in $291-Z$ & $\mathrm{VI}$ & $3 / 16 / 94$ & $4 / 7 / 94$ & WHC \\
\hline $94-200-109$ & Install Hoist in 234-5Z & VI & $3 / 16 / 94$ & $4 / 7 / 94$ & WHC \\
\hline $94-200-110$ & $\begin{array}{l}\text { Leak in Badgehouse Hydrovactor. } \\
\text { Discharge Line }\end{array}$ & 1 & $3 / 17 / 94$ & $3 / 17 / 94$ & KEH \\
\hline $94-200-111$ & Hole in Ground by Outside Flash Tank & 1. & $3 / 17 / 94$ & $3 / 18 / 94$ & $\mathrm{KEH}$ \\
\hline $94-200-112$ & Backflow Preventer in 2736-zb. & $\mathrm{Vl}$ & $3 / 17 / 94$ & $3 / 18 / 94$ & WHC \\
\hline $94-200-113$ & Repair 241-AX Raw Water Pipe & 1 & $3 / 21 / 94$ & $3 / 21 / 94$ & WHC \\
\hline $94-200-114$ & Draw Line to Drywell & III & $3 / 23 / 94$ & $3 / 28 / 94$ & \\
\hline $94-200-115$ & $\begin{array}{l}\text { W-402 Tank Farm Storg \& Staging } \\
\text { Facilities }\end{array}$ & III & $3 / 25 / 94$ & $3 / 28 / 94$ & WHC \\
\hline $94-200-116$ & Repair Water Line Leak by $202 \mathrm{~S}$ & 1 & $3 / 25 / 94$ & $3 / 28 / 94$ & WHC \\
\hline \multirow[t]{2}{*}{$94-200-117$} & U-2 Stainless Steel Pipe Integrity Testing & 1 & $3 / 28 / 94$ & $3 / 31 / 94$ & WHC \\
\hline & Rt. 4 Improvement Projects & III & $3 / 29 / 94$ & $4 / 7 / 94$ & $\mathrm{KEH}$ \\
\hline $94-200-119$ & Facility Upgrade - Bldg. 222B, 200E & VI & $3 / 30 / 94$ & $4 / 4 / 94$ & $\mathrm{KEH}$ \\
\hline $94-200-120$ & 241-A-701 Bldg Elect. Equip Replace & III & $4 / 5 / 94$ & $4 / 5 / 94$ & WHC \\
\hline $94-200-121$ & Replace Pumps/Motors/Switchgear & $\mathrm{VI}$ & $4 / 5 / 94$ & $4 / 13 / 94$ & $\mathrm{KEH}$ \\
\hline $94-200-122$ & Replace Boiler Feedwater Pumps in 284E & VI & $4 / 5 / 94$ & $4 / 13 / 94$ & $\mathrm{KEH}$ \\
\hline $94-200-123$ & 200W KEH Quality \& Safety Sign & III & $4 / 6 / 94$ & $4 / 12 / 94$ & $\mathrm{KEH}$ \\
\hline $94-200-124$ & Cyclone Fencing at PFP & .III' & $4 / 7 / 94$ & $4 / 14 / 94$ & WHC \\
\hline $94-200-125$ & Relocation \& Modification of MO953 & III & $4 / 7 / 94$ & $4 / 12 / 94$ & $\mathrm{KEH}$ \\
\hline $94-200-126$ & Painter Shop Electrical Upgrade & III & $4 / 8 / 94$ & $4 / 12 / 94$ & $\mathrm{KEH}$ \\
\hline $94-200-127$ & Compressor Station in 241-BY & III & $4 / 8 / 94$ & $4 / 12 / 94$ & $\mathrm{KEH}$ \\
\hline $94-200-128$ & Change Trailer Modification & III & $4 / 8 / 94$ & $4 / 13 / 94$ & WHC \\
\hline $94-200-129$ & $\begin{array}{l}\text { Conduit \& Ground Rods in 241-SX, TX, } \\
\text { TY }\end{array}$ & III & $4 / 8 / 94$ & $4 / 14 / 94$ & WHC \\
\hline
\end{tabular}




\begin{tabular}{|c|c|c|c|c|c|}
\hline $\begin{array}{c}\text { Case } \\
\text { Number }\end{array}$ & Project Name & Class & $\begin{array}{c}\text { Date } \\
\text { Received }\end{array}$ & 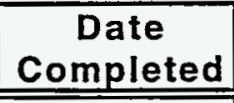 & \begin{tabular}{|l|} 
Requesting \\
Organization \\
\end{tabular} \\
\hline $94-200-130$ & $\begin{array}{l}\text { Remove Conduit \& Junction Boxes, Cut } \\
\text { Wires \& Cable }\end{array}$ & 1 & $4 / 13 / 94$ & $4 / 15 / 94$ & WHC \\
\hline $94-200-131$ & $\begin{array}{l}\text { Slting of Support Structure, Relocation \& } \\
\text { Mod. of M0832 }\end{array}$ & III & $4 / 14 / 94$ & $4 / 15 / 94$ & KEH \\
\hline $94-200-132$ & 216-T-1, 216-T-4-2 & III & $4 / 14 / 94$ & $4 / 15 / 94$ & WHC \\
\hline $94-200-133$ & L-207, Septic Holding Tank at MO291 & III & $4 / 18 / 94$ & $4 / 20 / 94$ & $\mathrm{KEH}$ \\
\hline $94-200-134$ & $\begin{array}{l}\text { 2Q-91-00953, Repair Pit/French Drain/ } \\
\text { Condensate Pipe Project }\end{array}$ & 1 & $4 / 18 / 94$ & $4 / 20 / 94$ & WHC \\
\hline $94-200-135$ & ICF Kaiser Facility Repair & III & $4 / 19 / 94$ & $4 / 20 / 94$ & KEH \\
\hline $94-200-136$ & Field Screening Support Facility & III & $4 / 20 / 94$ & $4 / 22 / 94$ & $\mathrm{KEH}$ \\
\hline $94-200-137$ & Repair Sprinkler Lines & 1 & $4 / 22 / 94$ & $4 / 22 / 94$ & $\mathrm{KEH}$ \\
\hline $94-200-138$ & L-132/2711E Septic System Tie Line & III & $4 / 22 / 94$ & $4 / 22 / 94$ & KEH \\
\hline $94-200-139$ & Repair Lawn Sprinkler System & 1 & $4 / 26 / 94$ & $4 / 27 / 94$ & WHC \\
\hline $94-200-140$ & Siting of Construction Support Facilities & III & $4 / 26 / 94$ & $4 / 27 / 94$ & KEH \\
\hline $94-200-141$ & 94G-EWW-401-Installation of MO-293 & III & $4 / 26 / 94$ & $4 / 27 / 94$ & $\mathrm{KEH}$ \\
\hline $94-200-142$ & Fiber Cable 272WA to MO233 & III & $4 / 27 / 94$ & $4 / 28 / 94$ & $\mathrm{KEH}$ \\
\hline $94-200-143$ & Repair Sanitary Water Line & 1 & $4 / 27 / 94$ & $4 / 28 / 94$ & WHC \\
\hline $94-200-144$ & Raw Water System at 244-BX & III & $4 / 27 / 94$ & $4 / 28 / 94$ & $\mathrm{KEH}$ \\
\hline $94-200-145$ & Project 3000 -Fence, Lights in $200 \mathrm{E}$ & III & $4 / 28 / 94$ & $5 / 3 / 94$ & $\mathrm{KEH}$ \\
\hline $94-200-146$ & Mod. of Constr. Support Fac., 20 & III & $4 / 28 / 94$ & $5 / 18 / 94$ & $\mathrm{KEH}$ \\
\hline $94-200-147$ & Upgrades in 241-BY Farm & III & $4 / 29 / 94$ & $4 / 29 / 94$ & WHC \\
\hline $94-200-148$ & MO Footings in Tank Farms & III & $4 / 29 / 94$ & $4 / 29 / 94$ & WHC \\
\hline $94-200-149$ & 274E: Repair Sewer Line & 1 & $5 / 2 / 94$ & $5 / 3 / 94$ & $\mathrm{KEH}$ \\
\hline $94-200-150$ & $\begin{array}{l}\text { Relocation/Mod. of MO855, Relocation of } \\
\text { Portable Storage Unit }\end{array}$ & III & $5 / 3 / 94$ & $5 / 4 / 94$ & $\mathrm{KEH}$ \\
\hline $94-200-151$ & 110-C Intrusion Barrier & III & $5 / 3 / 94$ & $5 / 4 / 94$ & WHC \\
\hline $94-200-152$ & 3 Wells in $200 \mathrm{~W}$ & III & $5 / 3 / 94$ & $5 / 4 / 94$ & WHC \\
\hline $94-200-153$ & Remove Overhead Guywire & 1 & $5 / 5 / 94$ & $5 / 5 / 94$ & $\mathrm{KEH}$ \\
\hline $94-200-154$ & Raising CASS Splice Boxes & 1 & $5 / 5 / 94$ & $5 / 11 / 94$ & WHC \\
\hline $94-200-155$ & Fence around $275 \mathrm{E}$ & III & $5 / 5 / 94$ & $5 / 10 / 94$ & $\mathrm{KEH}$ \\
\hline $94-200-156$ & $\begin{array}{l}\text { Auger Anchoring Device Pull-Out } \\
\text { Strength Test }\end{array}$ & III & $5 / 5 / 94$ & $5 / 11 / 94$ & KEH \\
\hline $94-200-157$ & $\begin{array}{l}\text { 221T/271T Roof Membrane } \\
\text { Replacements }\end{array}$ & $\mathrm{Vl}$ & $5 / 10 / 94$ & $5 / 18 / 94$ & KEH \\
\hline $94-200-158$ & Drum Storage Units & III & $5 / 10 / 94$ & $5 / 13 / 94$ & WHC \\
\hline $94-200-159$ & Repair Water Line & 1 & $5 / 10 / 94$ & $5 / 13 / 94$ & WHC \\
\hline $94-200-160$ & ER5798, Service to MO-535 & III & $5 / 10 / 94$ & $5 / 13 / 94$ & KEH \\
\hline $94-200-161$ & Tank 241-AW-101 Video Camera System & III & $5 / 12 / 94$ & $5 / 13 / 94$ & WHC \\
\hline $94-200-162$ & 2607-W2 Septic System Tie-In & III. & $5 / 13 / 94$ & $5 / 18 / 94$ & $\mathrm{KEH}$ \\
\hline $94-200-163$ & Conduit Stand at 103-S & III & $5 / 17 / 94$ & $5 / 18 / 94$ & WHC \\
\hline $94-200-164$ & Redox Raw/Sanitary Water Isolation & 1 & $5 / 17 / 94$ & $5 / 20 / 94$ & WHC \\
\hline $94-200-165$ & Conduit Stand at 107-S & III & $5 / 18 / 94$ & $5 / 19 / 94$ & WHC \\
\hline
\end{tabular}




\begin{tabular}{|c|c|c|c|c|c|}
\hline $\begin{array}{l}\text { Case } \\
\text { Number }\end{array}$ & Project Name & Class & $\begin{array}{c}\text { Date } \\
\text { Received } \\
\end{array}$ & $\begin{array}{c}\text { Date } \\
\text { Completed } \\
\end{array}$ & $\begin{array}{l}\text { Requesting } \\
\text { Organization }\end{array}$ \\
\hline $94-200-166$ & 200-BP-5 Unit 1 & III & $5 / 18 / 94$ & $5 / 20 / 94$ & WHC \\
\hline $94-200-167$ & Conduit Stands in Various Tank Farms & III & $5 / 18 / 94$ & $5 / 20 / 94$ & WHC \\
\hline $94-200-168$ & $\begin{array}{l}2 \mathrm{~W}-93-00293 \mathrm{M} \text { - Abandon Wires in 241- } \\
\mathrm{TX}\end{array}$ & 1 & $5 / 20 / 94$ & $5 / 23 / 94$ & WHC \\
\hline $94-200-169$ & $\begin{array}{l}\text { W-113 Solid Waste Retrieval Facility Soil } \\
\text { Load Bearing Test }\end{array}$ & $\overline{l 11}$ & $5 / 23 / 94$ & $5 / 25 / 94$ & $\overline{\mathrm{WHC}}$ \\
\hline $94-200-170$ & 241-TY Fire Hydrant Removal 1-TX & 1 & $5 / 23 / 94$ & $5 / 25 / 94$ & WHC \\
\hline $94-200-171$ & $\begin{array}{l}\text { 2E-94-00168N-Purge Air in 241-AN } \\
\text { Fam }\end{array}$ & III & $5 / 23 / 94$ & $5 / 25 / 94$ & WHC \\
\hline $94-200-172$ & Telephone Service to MO-434 & III & $5 / 25 / 94$ & $5 / 31 / 94$ & $\mathrm{KEH}$ \\
\hline $94-200-173$ & Provide Power to Skid Shack & III & $5 / 26 / 94$ & $5 / 31 / 94$ & KEH \\
\hline $94-200-174$ & 224-B Raw/Sanitary Water Isolation & 1 & $5 / 26 / 94$ & $5 / 31 / 94$ & WHC \\
\hline $94-200-175$ & $\begin{array}{l}\text { 218-E-8 Borrow Pit \& } 200 W \text { Ash Pit } \\
\text { Demo. Site }\end{array}$ & 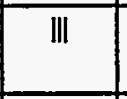 & $5 / 27 / 94$ & $6 / 9 / 94$ & WHC \\
\hline $94-200-1 \cdot 76$ & 241-C-104 Conduit Removal & 1 & $5 / 31 / 94$ & $6 / 1 / 94$ & KEH \\
\hline $94-200-177$ & Tank Monitoring \& Control Syst. Instl. & III & $5 / 31 / 94$ & $6 / 1 / 94$ & WHC \\
\hline $94-200-178$ & Watchlist Tank Hydrogen Monitors & III & $6 / 1 / 94$ & $6 / 2 / 94$ & WHC \\
\hline $94-200-179$ & Inspection and Repackaging Unit & III & $6 / 2 / 94$ & $6 / 9 / 94$ & WHC \\
\hline $94-200-180$ & 241-SY Soil Density Testing & III & $6 / 2 / 94$ & $6 / 9 / 94$ & WHC \\
\hline $94-200-181$ & Install One-Way Signs & III & $6 / 3 / 94$ & $6 / 9 / 94$ & KEH \\
\hline $94-200-182$ & Sld Waste Mgmt Config \& Health Physics & III & $6 / 9 / 94$ & $6 / 14 / 94$ & WHC \\
\hline $94-200-183$ & $\begin{array}{l}\text { Replace FIC Level Gauge from Tank 101- } \\
\text { AZ }\end{array}$ & $\mathrm{T}$ & $6 / 6 / 94$ & $6 / 10 / 94$ & WHC \\
\hline $94-200-184$ & Install Camera in AN-107 Riser & III & $6 / 9 / 94$ & $6 / 13 / 94$ & WHC \\
\hline 94-200-185 & Vehicle Ramp \& Effluent Monitoring Instl & III & $6 / 13 / 94$ & $6 / 16 / 94$ & WHC \\
\hline $94-200-186$ & $\begin{array}{l}\text { Repair Leaking Drain Valve on Fill Station } \\
\text { by Gate } 814\end{array}$ & .1 & $6 / 15 / 94$ & $6 / 21 / 94$ & KEH \\
\hline $94-200-187$ & L-235 CFIT Pilot Project & III & $6 / 17 / 94$ & $6 / 21 / 94$ & $\mathrm{KEH}$ \\
\hline $94-200-188$ & Leveling South of U-Plant & III & $6 / 20 / 94$ & $6 / 22 / 94$ & WHC \\
\hline $94-200-189$ & $\begin{array}{l}\text { Carbon Tetrachloride ERA Soil-Gas } \\
\text { Testing }\end{array}$ & III & $6 / 23 / 94$ & $6 / 27 / 94$ & WHC \\
\hline $94-200-190$ & Trenches at 241-SY Farm & III & $6 / 24 / 94$ & $6 / 28 / 94$ & WHC \\
\hline $94-200-191$ & Tank Farm Dome Loading, AY \& AZ Farms & 1 & $6 / 29 / 94$ & $6 / 29 / 94$ & WHC \\
\hline $94-200-192$ & $\begin{array}{l}\text { Installation of } 2 \text { Prefab Haz Waste Storage } \\
\text { Building }\end{array}$ & III & $6 / 29 / 94$ & $7 / 8 / 94$ & WHC \\
\hline $94-200-193$ & $\begin{array}{l}\text { 2E-94-00580-582: Conduit \& Tubing in } \\
241-A N\end{array}$ & III & $7 / 6 / 94$ & $7 / 7 / 94$ & WHC \\
\hline $94-200-194$ & $\begin{array}{l}\text { 241-BY Investigate RMCS Riser } \\
\text { Prospects }\end{array}$ & I. & $7 / 6 / 94$ & $7 / 8 / 94$ & WHC \\
\hline $94-200-195$ & 241-SY Impact Wrench Station & III & $7 / 1 / 94$ & $7 / 7 / 94$ & WHC \\
\hline $94-200-196$ & TMACS Tie-in to 106-BX ENRAF LIT & III & $7 / 12 / 94$ & $7 / 13 / 94$ & WHC \\
\hline
\end{tabular}




\begin{tabular}{|c|c|c|c|c|c|}
\hline $\begin{array}{l}\text { Case } \\
\text { Number }\end{array}$ & Project Name & Class & \begin{tabular}{c|} 
Date \\
Received \\
\end{tabular} & $\begin{array}{c}\text { Date } \\
\text { Completed } \\
\end{array}$ & $\begin{array}{l}\text { Requesting } \\
\text { Organization }\end{array}$ \\
\hline $94-200-197$ & Nitrogen Dewar Supply System SY-Farm & III & $.7 / 11 / 94$ & $7 / 13 / 94$ & WHC \\
\hline $94-200-198$ & DACS Trailer Power Cable Update & III & $7 / 12 / 94$ & $7 / 13 / 94$ & WHC \\
\hline $94-200-199$ & Tank SY-101 Hydrogen Mitigation & III & $7 / 12 / 94$ & $7 / 21 / 94$ & WHC \\
\hline $94-200-200$ & $\begin{array}{l}\text { Storage of Long Length Radioactive } \\
\text { Mixed Waste }\end{array}$ & III & $7 / 8 / 94$ & $7 / 20 / 94$ & WHC \\
\hline $94-200-201$ & Trench in SY Tank Farm & III & $7 / 15 / 94$ & $7 / 19 / 94$ & WHC \\
\hline $94-200-202$ & Paving in $200 \mathrm{~W}$ & 1 & $7 / 13 / 94$ & $7 / 22 / 94$ & WHC \\
\hline $94-200-203$ & 2E-93-01307/B-Excavate at $241-\mathrm{C}$ & III & $7 / 14 / 94$ & $7 / 22 / 94$ & WHC \\
\hline $94-200-204$ & Vapor Sampling & III & $7 / 15 / 94$ & $7 / 29 / 94$ & WHC \\
\hline $94-200-205$ & $\begin{array}{l}\text { Repave Gate } 810 \text { Access Rd from } 11 \mathrm{~A} \text { to } \\
200 E \text { Fence }\end{array}$ & 1 & $7 / 18 / 94$ & $8 / 9 / 94$ & KEH \\
\hline $94-200-206$ & $\begin{array}{l}\text { Serv. to } 241 \text { U/271 Bldg\&222B- } \\
\text { Place/Remove Cable }\end{array}$ & III & $7 / 20 / 94$ & $7 / 27 / 94$ & WHC \\
\hline $94-200-207$ & $\begin{array}{l}\text { SY Farm Instrumentation \& Control } \\
\text { Enclosures }\end{array}$ & III & $7 / 20 / 94$ & $7 / 22 / 94$ & WHC \\
\hline 94-200-208 & Removal of Asbestos Material & III & $7 / 27 / 94$ & $7 / 28 / 94$ & $\mathrm{KEH}$ \\
\hline $94-200-209$ & B-604 Water System Upgrade - Reservoir & V/III & $7 / 28 / 94$ & $8 / 29 / 94$ & $\mathrm{KEH}$ \\
\hline $94-200-210$ & $\begin{array}{l}\text { Install Permanent Pipe Support/2P-94- } \\
00612 / M\end{array}$ & III & $7 / 27 / 94$ & $8 / 5 / 94$ & KEH \\
\hline $94-200-211$ & TMACS Tie-in to 107-BX Enraf LIT & III & $7 / 22 / 94$ & $7 / 29 / 94$ & BTLR \\
\hline $94-200-212$ & $\begin{array}{l}\text { Repair Leaking Sanitary Water Line by } \\
\text { MO-257 }\end{array}$ & $\mathrm{I}$ & $7 / 27 / 94$ & $7 / 29 / 94$ & $\mathrm{KEH}$ \\
\hline $94-200-213$ & $\begin{array}{l}\text { S/SX Farms Thermo Monit. \& Control } \\
\text { System \& Power Restoration at 241-B }\end{array}$ & III & $7 / 27 / 94$ & $8 / 4 / 94$ & MCE \\
\hline $94-200-214$ & 2704-C Demolition & $\mathrm{VI}$ & $8 / 2 / 94$ & & $\mathrm{KEH}$ \\
\hline $94-200-215$ & Install Placement Gravity Drain & 1 & $8 / 3 / 94$ & $8 / 9 / 94$ & $\mathrm{KEH}$ \\
\hline $94-200-216$ & 2W-94-00790, 241-S Lines & 1 & $8 / 1 / 94$ & $8 / 4 / 94$ & WHC \\
\hline $94-200-217$ & Enclosure Fence at Electrical Laydown & III & $8 / 3 / 94$ & $8 / 10 / 94$ & WHC \\
\hline $94-200-218$ & Bldg 283E, Telephone Cable & III & $8 / 4 / 94$ & $8 / 10 / 94$ & BCSR \\
\hline $94-200-219$ & Air Chiller in C Farm & III & $8 / 8 / 94$ & $8 / 10 / 94$ & WHC \\
\hline $94-200-220$ & $\begin{array}{l}\text { Upgrade Bldg } 2719 \mathrm{EA} \text { - Health Service } \\
\text { Entrance, } 200 \mathrm{E}\end{array}$ & $\mathrm{VI}$ & $8 / 9 / 94$ & $8 / 11 / 94$ & KEH \\
\hline $94-200-221$ & $\begin{array}{l}\text { N2619 - ENRAF Level Indicator } \\
\text { Installation }\end{array}$ & III & $8 / 9 / 94$ & $8 / 10 / 94$ & WHC \\
\hline $94-200-222$ & Standard Hydrogen Monitoring System & III & $8 / 9 / 94$ & $8 / 10 / 94$ & WHC \\
\hline $94-200-223$ & Light Ballasts \& Wiring in 234-5Z & $\mathrm{VI}$ & $8 / 11 / 94$ & $8 / 17 / 94$ & WHC \\
\hline $94-200-224$ & $\begin{array}{l}\text { 2101M Lunchrooms Mods. \& } 328 \\
\text { Engraver Rm }\end{array}$ & $\mathrm{VI}$ & $8 / 11 / 94$ & $8 / 17 / 94$ & KEH \\
\hline $94-200-225$ & Arid ID Come Penetrometer Installations & III & $8 / 11 / 94$ & $8 / 15 / 94$ & $\mathrm{BH}$ \\
\hline $94-200-226$ & Pavillion Footings & III & $8 / 16 / 94$ & $8 / 18 / 94$ & WHC \\
\hline $94-200-227$ & Exploratory Corings in UO3 Area & III & $8 / 18 / 94$ & $8 / 18 / 94$ & WHC \\
\hline 94-200-228 & Cable Relief to $242 \mathrm{~A} / 200 \mathrm{E}$ & III & $8 / 17 / 94$ & $8 / 19 / 94$ & BCSR \\
\hline
\end{tabular}




\begin{tabular}{|c|c|c|c|c|c|}
\hline Case & Project Name & Class & $\begin{array}{c}\text { Date } \\
\text { Received } \\
\end{array}$ & $\begin{array}{c}\text { Date } \\
\text { Completed } \\
\end{array}$ & $\begin{array}{c}\text { Requesting } \\
\text { Organization } \\
\end{array}$ \\
\hline $94-200-229$ & Service to 200ZP1 Treatability & III & $8 / 17 / 94$ & $8 / 19 / 94$ & BCSR \\
\hline $94-200-230$ & $\begin{array}{l}\text { Electrical Serv. to 219-S, MO-037, 2704- } \\
\text { S \& MO-924 }\end{array}$ & III & $8 / 19 / 94$ & $8 / 23 / 94$ & KEH \\
\hline $94-200-231$ & Uncover and Re-align Pipe Casing & 1 & $8 / 24 / 94$ & $8 / 25 / 94$ & WHC \\
\hline $94-200-232$ & $\begin{array}{l}\text { 2D-93-289-Security Fence at Storage } \\
\text { Yard }\end{array}$ & III & $8 / 25 / 94$ & $8 / 26 / 94$ & $\mathrm{KEH}$ \\
\hline $94-200-233$ & A Farm Support Complex Electrical & III & $8 / 30 / 94$ & $8 / 31 / 94$ & $\mathrm{KEH}$ \\
\hline $94-200-234$ & Wooden Air Sampling Buildings (4) & VI & $8 / 26 / 94$ & & WHC \\
\hline $94-200-235$ & PFP.HLAN Upgrade & III & $8 / 30 / 94$ & $8 / 31 / 94$ & WHC \\
\hline 94-200-236 & 200-UP-Z Central Drum Storage Area & III & $9 / 1 / 94$ & $9 / 2 / 94$ & $\pi$ \\
\hline $94-200-237$ & $\begin{array}{l}\text { Telephone Service to Fiber Optic Huts in } \\
200 E \& 200 \mathrm{~W}\end{array}$ & III & $9 / 1 / 94$ & $9 / 2 / 94$ & BCSR \\
\hline $94-200-238$ & $\begin{array}{l}\text { 216-U-14 \& 216-B-63 Ditches Interim } \\
\text { Stabiliz. }\end{array}$ & III & $9 / 7 / 94$ & $9 / 8 / 94$ & WHC \\
\hline 94-200-239 & Tunable Hybrid Plasma (\#18687) & III & $9 / 8 / 94$ & $9 / 12 / 94$ & PNL \\
\hline $94-200-240$ & Leveling at $218-E-10$ & III & $9 / 9 / 94$ & $9 / 12 / 94$ & WHC \\
\hline $94-200-241$ & Installing HVAC at $2101-\mathrm{M}$ & III & $9 / 12 / 94$ & $9 / 16 / 94$ & KEH \\
\hline $94-200-242$ & 2719-WA Demolition & $\mathrm{VI}$ & $9 / 13 / 94$ & & $\mathrm{KEH}$ \\
\hline 94-200-243 & Trench at UO3 Plant & III & 9/13/94 & $9 / 15 / 94$ & WHC \\
\hline $94-200-244$ & Test Sites West of T Plant & III & $9 / 14 / 94$ & $9 / 15 / 94$ & \\
\hline $94-200-245$ & $\begin{array}{l}200 \text { Area Interior Rds \& Sidewalks } \\
\text { Upgrade (L-221) }\end{array}$ & III & $9 / 16 / 94$ & $9 / 20 / 94$ & KEH \\
\hline $94-200-246$ & 271-T Ventilation & $\mathrm{VI}$ & $9 / 27 / 94$ & $10 / 3 / 94$ & WHC \\
\hline $94-200-247$ & $\begin{array}{l}\text { MO412, 200W, 20th St East Conduit } \\
\text { Placement }\end{array}$ & III & $9 / 22 / 94$ & $9 / 23 / 94$ & BCSR \\
\hline $94-200-248$ & Winterization Upgrades to PFP & $\mathrm{VI}$ & $9 / 22 / 94$ & $9 / 23 / 94$ & WHC \\
\hline $94-200-249$ & Navy Core Basket Shipment & III & $9 / 23 / 94$ & $9 / 23 / 94$ & WHC \\
\hline $94-200-250$ & W-049H, 200 Area TEDF & III & $9 / 29 / 94$ & $9 / 30 / 94$ & WHC \\
\hline 94-200-251 & Isolate Water Supply to 2724 & 1 & $9 / 28 / 94$ & $9 / 29 / 94$ & KEH \\
\hline 94-300-001 & $\begin{array}{l}\text { 93L-EWL-097, Fire Alarm Syst Improve., } \\
300 \text { Area }\end{array}$ & VI & $10 / 1 / 93$ & $10 / 4 / 93$ & WHC \\
\hline 94-300-002 & Leaking Pipe at 337's High Bay Bldg & 1 & $10 / 7 / 93$ & $10 / 11 / 93$ & WHC \\
\hline 94-300-003 & Tank Removal at $301 \mathrm{Bldg}^{\circ}$ & III & $10 / 15 / 93$ & $10 / 20 / 93$ & WHC \\
\hline 94-300-004 & Tank Removal at $309 \mathrm{Bldg}$ & III & $10 / 15 / 93$ & $10 / 20 / 93$ & WHC \\
\hline $94-300-005$ & $\begin{array}{l}\text { Safety Compliance Modifications, 326B } \\
\text { Bldg, D-388 }\end{array}$ & III & $10 / 21 / 93$ & $10 / 22 / 93$ & PNL \\
\hline $94-300-006$ & $\begin{array}{l}\text { Project L-182, Surface Water Treatment } \\
\text { Rule }\end{array}$ & III & $10 / 25 / 93$ & $10 / 28 / 93$ & WHC \\
\hline $94-300-007$ & $331 /$ U-1 Shallow Pit & 1 & $10 / 26 / 93$ & $10 / 28 / 93$ & WHC \\
\hline $94-300-008$ & 300 Area South Office Building & $\mathrm{V}$ & $10 / 27 / 93$ & & WHC \\
\hline 94-300-009 & 328 Building Guardrail Installation & $\mathrm{VI}$ & $10 / 27 / 93$ & $10 / 28 / 93$ & WHC \\
\hline 94-300-010 & 328 Emergency Lighting & $\mathrm{Vl}$ & $10 / 27 / 93$ & $10 / 28 / 93$ & WHC \\
\hline $94-300-011$ & 3790 Bldg Stairwell Canopies & $\mathrm{Vl}$ & $10 / 28 / 93$ & $11 / 5 / 93$ & WHC \\
\hline $94-300-012$ & Modification of 338 Building & III & $11 / 1 / 93$ & $11 / 1 / 93$ & $\mathrm{KEH}$ \\
\hline $94-300-013$ & 3707-B Building Demolition & $\mathrm{VI}$ & $11 / 1 / 93$ & & $\mathrm{KEH}$ \\
\hline
\end{tabular}




\begin{tabular}{|c|c|c|c|c|c|}
\hline $\begin{array}{l}\text { Case } \\
\text { Number }\end{array}$ & Project Name & Class & $\begin{array}{c}\text { Date } \\
\text { Received }\end{array}$ & $\begin{array}{c}\text { Date } \\
\text { Completed } \\
\end{array}$ & $\begin{array}{l}\text { Requesting } \\
\text { Organization }\end{array}$ \\
\hline $94-300-014$ & 331 Bldg Lobby Upgrade & $\mathrm{VI}$ & $11 / 3 / 93$ & $11 / 5 / 93$ & PNL \\
\hline $94-300-015$ & $\mathrm{~L}-045 \mathrm{H}$ & IV & $11 / 17 / 93$ & & WHC \\
\hline $94-300-016$ & Lease of 313 Building & $\mathrm{VI}$ & $10 / 22 / 93$ & & WHC \\
\hline $94-300-017$ & HVAC Upgrades, JIN D00040 & III & $12 / 2 / 93$ & $12 / 6 / 93$ & PNL \\
\hline $94-300-018$ & $\begin{array}{l}\text { Alternate Water Source to the } 308 \\
\text { Building TRIGA B }\end{array}$ & III & $12 / 13 / 93$ & $12 / 15 / 93$ & WHC \\
\hline $94-300-019$ & Process Water Connection Installation & Vl & $12 / 13 / 93$ & $12 / 15 / 93$ & WHC \\
\hline $94-300-020$ & 3705 Roof Access Ladder Replacement & $\mathrm{VI}$ & $12 / 15 / 93$ & $12 / 17 / 93$ & KEH \\
\hline 94-300-021 & 3707D Electrical System Modifications & $\mathrm{Vl}$ & $12 / 15 / 93$ & $12 / 17 / 93$ & $\mathrm{KEH}$ \\
\hline $94-300-022$ & $\begin{array}{l}325 \text { Bldg, Route Drain to Sanitary Sewerl } \\
\text { Men's Shower Rm Mods }\end{array}$ & $\mathrm{VI}$ & $12 / 21 / 93$ & $12 / 21 / 93$ & PNL \\
\hline $94-300-023$ & $\begin{array}{l}324 \text { Bldg, Halon Bottle Removal, ER } \\
3409\end{array}$ & VI & $12 / 21 / 93$ & $12 / 22 / 93$ & PNL \\
\hline $94-300-024$ & Badgehouse Demolitions & $\mathrm{VI}$ & $12 / 31 / 93$ & $6 / 20 / 94$ & WHC \\
\hline $94-300-025$ & $\begin{array}{l}\text { E-022,Motor Control Center } \\
\text { Replacement,315 Facility }\end{array}$ & IV & $12 / 31 / 93$ & $1 / 13 / 94$ & WHC \\
\hline $94-300-026$ & Lab Addition, 336 & III & $1 / 6 / 94$ & $1 / 13 / 94$ & PNL \\
\hline $94-300-027$ & Melters in 324 Bldg & $\mathrm{VI}$ & $12 / 22 / 93$ & $1 / 13 / 94$ & PNL \\
\hline $94-300-028$ & $\begin{array}{l}\text { Non-Radioactive Demonstration of } \\
\text { Cesium lon-Exchange CPU }\end{array}$ & Vl & $1 / 13 / 94$ & $1 / 14 / 94$ & PNL \\
\hline $94-300-029$ & $\begin{array}{l}\text { Isolate Sanitary Water \& Safety Shower } \\
\text { Water Supply to } 308\end{array}$ & $\mathrm{~T}$ & $1 / 20 / 94$ & $1 / 21 / 94$ & WHC \\
\hline $94-300-030$ & $\begin{array}{l}\text { Repair Condensate Line near } 384 \text { \& } \\
\text { Steam Line near } 382\end{array}$ & $\mathrm{I}$ & $1 / 20 / 94$ & $1 / 21 / 94$ & WHC \\
\hline $94-300-031$ & Roof Repair for 328 Building & $\mathrm{Vl}$ & $1 / 24 / 94$ & $1 / 25 / 94$ & WHC \\
\hline $94-300-032$ & Repair of Pipes behind the 327 Bldg & 1 & $1 / 26 / 94$ & $1 / 27 / 94$ & WHC \\
\hline $94-300-033$ & Repair 300 Area Steam Vaults & 1 & $2 / 4 / 94$ & $2 / 9 / 94$ & WHC \\
\hline $94-300-034$ & Expose Roof Slab at U-7 Pit & 1 & $2 / 7 / 94$ & $2 / 8 / 94$ & WHC \\
\hline $94-300-035$ & Conduit to 300 Area Conex Boxes & III & $2 / 10 / 94$ & $2 / 15 / 94$ & WHC \\
\hline $94-300-036$ & Lease of 308 or 309 & $\mathrm{VI}$ & $2 / 14 / 94$ & & WHC \\
\hline 94-300-037 & $\begin{array}{l}300 \text { Area Fuels Production Facilities } \\
\text { Stabilization }\end{array}$ & $\mathrm{Vl}$ & $2 / 23 / 94$ & $4 / 11 / 94$ & WHC \\
\hline $94-300-038$ & $\begin{array}{l}\text { Aquatic Lab \& Shop Conversion, } 331 \\
\text { Bldg; Renovation of Lab Space } 324 \text { Bldg }\end{array}$ & $\mathrm{VI}$ & $2 / 24 / 94$ & $2 / 25 / 94$ & PNL \\
\hline $94-300-039$ & $\begin{array}{l}\text { Equipment Modifications, } 325 \text { Bldg, } \\
\# D 00672\end{array}$ & $\mathrm{VI}$ & $2 / 24 / 94$ & $2 / 25 / 94$ & PNL \\
\hline $94-300-040$ & $\begin{array}{l}\text { Install Guardrails in } 309 \text { Roof and } 3790 \\
\text { Bldg }\end{array}$ & $\mathrm{Vl}$ & $3 / 3 / 94$ & $3 / 7 / 94$ & KEH \\
\hline $94-300-041$ & K003, Multipurpose Facility & IV & $3 / 8 / 94$ & & $\mathrm{KEH}$ \\
\hline $94-300-042$ & Transition of 313 Building to $D \& D$ & VI & $3 / 18 / 94$ & & WHC \\
\hline $94-300-043$ & Roof Slab at U-65 Steam Pit & 1 & $3 / 25 / 94$ & $.3 / 28 / 94$ & WHC \\
\hline $94-300-044$ & D-460, Office Addition, 331 Bldg & III & $3 / 31 / 94$ & $4 / 8 / 94$ & PNL \\
\hline $94-300-045$ & Well Remediation: 399-01-09 & 1 & $4 / 6 / 94$ & $4 / 11 / 94$ & WHC \\
\hline $94-300-046$ & 3714 Bldg Telephone Service Installation & III & $4 / 7 / 94$ & $4 / 11 / 94$ & $\mathrm{KEH}$ \\
\hline
\end{tabular}




\begin{tabular}{|c|c|c|c|c|c|}
\hline $\begin{array}{c}\text { Case } \\
\text { Number }\end{array}$ & Project Name & Class & $\begin{array}{c}\text { Date } \\
\text { Received }\end{array}$ & $\begin{array}{c}\text { Date } \\
\text { Completed } \\
\end{array}$ & $\begin{array}{l}\text { Requesting } \\
\text { Organization }\end{array}$ \\
\hline $94-300-047$ & $\begin{array}{l}\text { Install Night Lights \& New Piping Around } \\
\text { \& Inside } 384 \text { Bldg }\end{array}$ & III & $4 / 6 / 94$ & $4 / 13 / 94$ & WHC \\
\hline $94-300-048$ & Conference Room Mods, 320 Bldg. & $\mathrm{VI}$ & $4 / 11 / 94$ & $4 / 15 / 94$ & PNL \\
\hline 94-300-049 & Support Warehouse, 324 Bldg. & III & $4 / 11 / 94$ & $4 / 14 / 94$ & PNL \\
\hline $94-300-050$ & Renovation of Offices in $324 \mathrm{Bidg}$. & VI & $4 / 12 / 94$ & $4 / 15 / 94$ & PNL \\
\hline 9 & $\begin{array}{l}300 \text { Area Electrical Distribution } \\
\text { Conversion- South of } 300 \text { Area }\end{array}$ & III & $5 / 1 / 94$ & $5 / 19 / 94$ & KEH \\
\hline $94-300-052$ & NEC Code Corrections & III & $4 / 21 / 94$ & $4 / 26 / 94$ & PNL \\
\hline $94-300-053$ & 2 Trenches Near 308 & III & $4 / 22 / 94$ & $4 / 26 / 94$ & WHC \\
\hline 94-300-054 & Stack Monitor Upgrade, 327 Building & III & $4 / 26 / 94$ & $5 / 18 / 94$ & PNL \\
\hline $94-300-055$ & \begin{tabular}{|l|} 
D-391, 325 Facility \\
Compliance/Renovation
\end{tabular} & III & $4 / 26 / 94$ & $5 / 18 / 94$ & PNL \\
\hline $94-300-056$ & Operable Unit 300-FF-1 & III & $4 / 26 / 94$ & $5 / 12 / 94$ & PNL \\
\hline 94-300-057 & 600 Amp Service with 800 Amp Service & III & $4 / 26 / 94$ & $5 / 3 / 94$ & PNL \\
\hline $94-300-058$ & Room 22 Wall Installation for 325 Bldg & $\mathrm{Vl}$ & $5 / 3 / 94$ & $5 / 5 / 94$ & PNL \\
\hline $94-300-059$ & $\begin{array}{l}\text { TRU \& Moisture Measurements in HLW } \\
\text { Tanks }\end{array}$ & VI & $5 / 5 / 94$ & $5 / 17 / 94$ & PNL \\
\hline $94-300-060$ & Service to $339 \mathrm{~A}$ Bldg & III & $5 / 10 / 94$ & $5 / 13 / 94$ & $\mathrm{KEH}$ \\
\hline $94-300-061$ & 325 Building Upgrades & III & $5 / 13 / 94$ & $7 / 15 / 94$ & PNL \\
\hline $94-300-062$ & Leaking Water Valves at $327 \& 3706$ & 1 & $5 / 16 / 94$ & $5 / 18 / 94$ & WHC \\
\hline $94-300-063$ & $\begin{array}{l}\text { D-432 Particle-Accelerator Biophysical } \\
\text { Lab Addition Project }\end{array}$ & IIII & $5 / 19 / 94$ & $6 / 3 / 94$ & PNL \\
\hline $94-300-064$ & 309 Building Transition to D\&D & $\mathrm{VI}$ & $5 / 23 / 94$ & $7 / 22 / 94$ & WHC \\
\hline $94-300-065$ & Women's Change Rm, 327 Bldg, D00708 & $\mathrm{Vl}$ & $5 / 31 / 94$ & $6 / 3 / 94$ & PNL \\
\hline $94-300-066$ & $\begin{array}{l}\text { 324C Lithium Equipment Removal \& } \\
\text { Disposition }\end{array}$ & III & $6 / 1 / 94$ & $6 / 21 / 94$ & WHC \\
\hline $94-300-067$ & 313 Bldg Security Fencing & III & $6 / 14 / 94$ & $6 / 21 / 94$ & $\mathrm{KEH}$ \\
\hline $94-300-068$ & Paving of Area North of 324 Bldg Yard & III & $6 / 14 / 94$ & $6 / 16 / 94$ & PNL \\
\hline $94-300-069$ & Fuels Supply Trailer & III & $6 / 22 / 94$ & $6 / 24 / 94$ & WHC \\
\hline $94-300-070$ & Remove Water Service from South 313 & III & $6 / 28 / 94$ & $6 / 29 / 94$ & WHC \\
\hline $94-300-071$ & $\begin{array}{l}\text { VOC Integrated Demonstration, } N \text { of } 300 \\
\text { Area. }\end{array}$ & III & $7 / 7 / 94$ & $7 / 13 / 94$ & WHC \\
\hline $94-300-072$ & $\begin{array}{l}\text { Reroofing of Bldgs } 3701 \mathrm{D}, 3707 \mathrm{D}, 3709, \\
\text { and } 3713\end{array}$ & $\mathrm{VI}$ & $7 / 12 / 94$ & $7 / 21 / 94$ & $\mathrm{KEH}$ \\
\hline $94-300-073$ & Roof Replaçement, 331 Bldg & $\mathrm{VI}$ & $7 / 18 / 94$ & $7 / 27 / 94$ & PNL \\
\hline $94-300-074$ & 320 Building Laboratory Modifications & $\mathrm{VI}$ & $7 / 18 / 94$ & $7 / 27 / 94$ & PNL \\
\hline $94-300-075$ & 3702 Demolition & $\mathrm{V} !$ & $7 / 19 / 94$ & & KEH \\
\hline 94-300-076 & 3703 Demolition & $\mathrm{VI}$ & $7 / 19 / 94$ & & $\mathrm{KEH}$ \\
\hline $94-300-077$ & 3706A Demolition & $\mathrm{VI}$ & $7 / 19 / 94$ & & KEH \\
\hline $94-300-078$ & 3706 Demolition & $\mathrm{VI}$ & $7 / 19 / 94$ & & $\mathrm{KEH}$ \\
\hline $94-300-079$ & Install Ground Rods North of 313 & III & $8 / 10 / 94$ & $8 / 10 / 94$ & $\mathrm{KEH}$ \\
\hline $94-300-080$ & L-070 & III & $8 / 10 / 94$ & $10 / 25 / 94$ & BCSR \\
\hline
\end{tabular}




\begin{tabular}{|c|c|c|c|c|c|}
\hline $\begin{array}{c}\text { Case } \\
\text { Number }\end{array}$ & Project Name & Class & $\begin{array}{c}\text { Date } \\
\text { Received } \\
\end{array}$ & $\begin{array}{c}\text { Date } \\
\text { Completed } \\
\end{array}$ & \begin{tabular}{|l|} 
Requesting \\
Organization \\
\end{tabular} \\
\hline $94-300-081$ & $\begin{array}{l}\text { ER6104, Swinging Entry Gate } \\
\text { Installations }\end{array}$ & $\mathrm{VI}$ & $8 / 19 / 94$ & $8 / 23 / 94$ & KEH \\
\hline $94-300-082$ & $327 / 328$ Sidewalk Installation & III & $8 / 22 / 94$ & $8 / 23 / 94$ & KEH \\
\hline $94-300-083$ & $\begin{array}{l}\text { ER6150, } 337 \text { Bldg Retaining Wall } \\
\text { Installation }\end{array}$ & IV & $8 / 30 / 94$ & $8 / 31 / 94$ & KEH \\
\hline $94-300-084$ & Radioactive Materials Storage Area & IV & $8 / 25 / 94$ & $9 / 13 / 94$ & PNL \\
\hline 94-300-085 & Paving Near 3707-D & 1 & $8 / 25 / 94$ & $8 / 31 / 94$ & $\mathrm{KEH}$ \\
\hline $94-300-086$ & 3765 \& 3766, Paint Exterior Siding \& Trim & $\mathrm{VI}$ & $8 / 26 / 94$ & $9 / 8 / 94$ & KEH \\
\hline $94-300-087$ & $\begin{array}{l}\text { Project V-784, } 300 \text { Area Sanitary Sewer } \\
\text { Upgrades - South of } 300 \text { Area }\end{array}$ & IV & $8 / 30 / 94$ & $3 / 29 / 95$ & KEH \\
\hline $94-300-088$ & 2 Boreholes near $340 \mathrm{~B}$ & III & $9 / 8 / 94$ & $9 / 8 / 94$ & WHC \\
\hline $94-300-089$ & South Entry Mods, 3760 Bldg, D00985 & $\mathrm{VI}$ & $9 / 2 / 94$ & $9 / 15 / 94$ & PNL \\
\hline $94-300-090$ & Laser Lab \& Safety Mods & $\overline{V I}$ & $9 / 8 / 94$ & $9 / 9 / 94$ & PNL \\
\hline 94-300-091 & $300-F F-1 \& 300-F F-5$ & IV & $9 / 6 / 94$ & & WHC \\
\hline $94-300-092$ & Hydraulic Test Bed Project & $\mathrm{VI}$ & $9 / 26 / 94$ & $10 / 3 / 94$ & WHC \\
\hline 94-300-093 & 300 Area TEDF Paving & III & $9 / 27 / 94$ & $10 / 28 / 94$ & WHC \\
\hline $94-300-094$ & Service to New Mobile North of MO-543 & III & $9 / 29 / 94$ & $10 / 3 / 94$ & BCSR \\
\hline $94-400-001$ & $\begin{array}{l}\text { Install Larger Dust Collector System in } \\
\text { Building } 4\end{array}$ & III & $10 / 18 / 93$ & $10 / 18 / 93$ & WHC \\
\hline $94-400-002$ & $\begin{array}{l}\text { FMEF/FAA BIdgs } 427 / 4862 \text { Roof Repair } \\
\text { \& Penetration }\end{array}$ & VI & $1 / 19 / 94$ & $1 / 21 / 94$ & KEH \\
\hline $94-400-003$ & $\begin{array}{l}\text { Modifications to Buildings } 427,4701 \mathrm{C}, \\
4802,4862\end{array}$ & $\mathrm{VI}$ & $2 / 2 / 94$ & $2 / 7 / 94$ & WHC \\
\hline $94-400-004$ & $\begin{array}{l}\text { Removal of Underground Stor. Tank } 400- \\
\text { FMEF-T17 }\end{array}$ & I & $2 / 9 / 94$ & $2 / 10 / 94$ & WHC \\
\hline $94-400-005$ & $\begin{array}{l}\text { Handicapped Access Doors for } 4706 \\
\text { Bldg }\end{array}$ & $\mathrm{VI}$ & $3 / 2 / 94$ & $3 / 2 / 94$ & KEH \\
\hline $94-400-006$ & Fill Pipe Penetrations with Concrete & $\mathrm{VI}$ & $3 / 2 / 94$ & $3 / 3 / 94$ & KEH \\
\hline $94-400-007$ & Hand Geometry Installation & III & $3 / 15 / 94$ & $3 / 15 / 94$ & WHC \\
\hline $94-400-008$ & FFTF Shutdown Project & III & $5 / 9 / 94$ & $6 / 23 / 94$ & WHC \\
\hline $94-400-009$ & $\begin{array}{l}\text { Aerial Platform for Geophysical Detection } \\
\text { of Underground Structures }\end{array}$ & III & $6 / 15 / 94$ & $6 / 21 / 94$ & PNL \\
\hline $94-400-010$ & New Asphalt Walkways - FMEF Facility & III & $7 / 27 / 94$ & $8 / 4 / 94$ & KEH \\
\hline $94-400-011$ & FMEF Entry Portal Modification & $\mathrm{VI}$ & $8 / 10 / 94$ & $8 / 17 / 94$ & KEH \\
\hline 94-400-012 & 4814 \& 4843 Building Painting & $\mathrm{VI}$ & $8 / 24 / 94$ & $9 / 7 / 94$ & $\mathrm{KEH}$ \\
\hline $94-400-013$ & Fire Hydrant Repair - 408-B & 1 & $9 / 12 / 94$ & $9 / 13 / 94$ & $\mathrm{KEH}$ \\
\hline 94-600-001 & Spent Nuclear Fuel Storage Facility & III & $10 / 20 / 93$ & $11 / 15 / 93$ & PNL \\
\hline $94-600-002$ & $\begin{array}{l}\text { Concrete Sidewalks--South of } 200 E \text { Main } \\
\text { Gate }\end{array}$ & III & $10 / 27 / 93$ & $10 / 28 / 93$ & WHC \\
\hline
\end{tabular}




\begin{tabular}{|c|c|c|c|c|c|}
\hline $\begin{array}{l}\text { Case } \\
\text { Number }\end{array}$ & Project Name & Class & $\begin{array}{c}\text { Date } \\
\text { Received }\end{array}$ & $\begin{array}{c}\text { Date } \\
\text { Completed } \\
\end{array}$ & $\begin{array}{l}\text { Requesting } \\
\text { Organization }\end{array}$ \\
\hline 94-600-003 & Basalt Quarry Sites & IV & $11 / 3 / 93$ & & WHC \\
\hline 94-600-004 & 600 Area Pipeyard, Wash Station & III & $11 / 10 / 93$ & $11 / 15 / 93$ & WHC \\
\hline $94-600-005$ & $\begin{array}{l}\text { Repair Water Line Leaks by } 251 \\
\text { Substation \& } 212 \mathrm{~PB}\end{array}$ & 1 & $11 / 10 / 93$ & $11 / 15 / 93$ & WHC \\
\hline $94-600-006$ & $\begin{array}{l}\text { Repair Water Valve Leak on Export Line } \\
\text { Drain }\end{array}$ & 1 & $11 / 18 / 93$ & $11 / 29 / 93$ & WHC \\
\hline $94-600-007$ & $\begin{array}{l}\text { Fence Installation, Patrol Training } \\
\text { Academy }\end{array}$ & IIII & $11 / 22 / 93$ & $11 / 29 / 93$ & WHC \\
\hline $94-600-008$ & L-094, Fire Department Facilities & $\mathrm{V}$ & $11 / 23 / 93$ & & WHC \\
\hline $94-600-009$ & $\begin{array}{l}\text { Rattlesnake Mountain Tower-Benton } \\
\text { County PUD }\end{array}$ & $\bar{V}$ & $7 / 26 / 93$ & & BCPUD \\
\hline $94-600-010$ & Guardstation Installation at Wye Barricade & III & $12 / 3 / 93$ & $12 / 9 / 93$ & WHC \\
\hline 94-600-011 & Patrol Academy Landscaping & III & $12 / 9 / 93$ & $12 / 15 / 93$ & WHC \\
\hline $94-600-012$ & FLTF Renovation & 1 & $12 / 10 / 93$ & $12 / 14 / 93$ & PNL \\
\hline $94-600-013$ & Land Transfer of Sessler Property & $\mathrm{V}$ & $12 / 13 / 93$ & & $\mathrm{DOE}$ \\
\hline $94-600-014$ & 607 Bldg Storage Building & III & $12 / 28 / 93$ & $1 / 7 / 94$ & KEH \\
\hline $94-600-015$ & ALE Area Cleanup Sites & III & $1 / 3 / 94$ & $5 / 18 / 94$ & USACE \\
\hline 94-600-016 & WSGF Second 10-Wide MO-292 & III & $1 / 12 / 94$ & $1 / 12 / 94$ & WHC \\
\hline $94-600-017$ & $\begin{array}{l}\text { Spent Nuclear Fuel Storage Facility - Area } \\
2\end{array}$ & $\mathrm{~V}$ & $1 / 18 / 94$ & & PNL \\
\hline 94-600-018 & Well Decommissioning & III & $1 / 20 / 94$ & & WHC \\
\hline 94-600-019 & 2X-93-231, Trench near 616 & III. & $1 / 25 / 94$ & $1 / 26 / 94$ & WHC \\
\hline $94-600-020$ & $\begin{array}{l}\text { Rip-Rap for WPPSS Tower on } \\
\text { Rattlesnake }\end{array}$ & $\llbracket$ & $1 / 25 / 94$ & $1 / 26 / 94$ & DOE \\
\hline $94-600-021$ & Gravity Experiment on Rattlesnake & IV & $1 / 24 / 94$ & & \\
\hline $94-600-022$ & Horn Rapids Landfill & $n / a$ & $1 / 13 / 94$ & & USACE \\
\hline $94-600-023$ & Microbial Heterogeneity Research 1994 & $\mathrm{~V}$ & $2 / 15 / 94$ & & PNL \\
\hline $94-600-024$ & $\begin{array}{l}\text { Hanford Site Surface Environmental } \\
\text { Surveillance } \mathrm{Pr}\end{array}$ & III & $2 / 22 / 94$ & $5 / 5 / 94$ & PNL \\
\hline \multirow[t]{2}{*}{$94-600-025$} & Elevation Monuments & III & $2 / 24 / 94$ & $3 / 2 / 94$ & JEC \\
\hline & $\begin{array}{l}\text { Patrol Training Academy - Range \#1 } \\
\text { Target Installation }\end{array}$ & III & $2 / 24 / 94$ & $2 / 28 / 94$ & KEH \\
\hline $94-600-027$ & LO-Power AM Radio Broadcast Stations & III & $3 / 2 / 94$ & $3 / 17 / 94$ & WHC \\
\hline $94-600-028$ & $\begin{array}{l}\text { UN-216-E-41, X-Site Transfer Line Interim } \\
\text { Stabilization }\end{array}$ & III & $3 / 4 / 94$ & $3 / 15 / 94$ & WHC \\
\hline $94-600-029$ & W-320, Tank Farm 241-C Sluicing & III & $3 / 14 / 94$ & $3 / 15 / 94$ & WHC \\
\hline 94-600-030 & Install Lights around Flag Pole & III & $3 / 14 / 94$ & $3 / 17 / 94$ & KEH \\
\hline $94-600-031$ & $\begin{array}{l}\text { Construct } 13.8 \mathrm{KV} \text { Bypass at } 251 \mathrm{~W} \\
\text { Substation }\end{array}$ & III & $3 / 17 / 94$ & $3 / 18 / 94$ & $\mathrm{KEH}$ \\
\hline \multirow[t]{2}{*}{$94-600-032$} & Topographic Survey for Area S of $200 \mathrm{~W}$ & III & $3 / 15 / 94$ & $4 / 6 / 94$ & USACE \\
\hline & Cleanup at Well Site 699-42-39A \& B & III & $4 / 6 / 94$ & $4 / 11 / 94$ & WHC \\
\hline 94-600-034 & ERDF - Project W-296 - NE Portion & V & $4 / 22 / 94$ & & WHC \\
\hline
\end{tabular}




\begin{tabular}{|c|c|c|c|c|c|}
\hline $\begin{array}{c}\text { Case } \\
\text { Number }\end{array}$ & Project Name & Class & $\begin{array}{c}\text { Date } \\
\text { Received }\end{array}$ & $\begin{array}{c}\text { Date } \\
\text { Completed } \\
\end{array}$ & $\begin{array}{l}\text { Requesting } \\
\text { Organization } \\
\end{array}$ \\
\hline $94-600-035$ & Subsurface Science Program & $\mathrm{V}$ & $4 / 29 / 94$ & $5 / 4 / 94$ & PNL \\
\hline $94-600-036$ & Groundwater Surveillance/11246 & III & $4 / 29 / 94$ & $5 / 17 / 94$ & PNL \\
\hline $94-600-037$ & GTE/United Telephone Easements & $\mathrm{n} / \mathrm{a}$ & $5 / 3 / 94$ & & $\mathrm{DOE}$ \\
\hline $94-600-038$ & $\begin{array}{l}\text { Replace Lead Acid Battery Cells, RRHW } \\
\text { Crossing \#1 }\end{array}$ & 1 & $5 / 4 / 94$ & $5 / 5 / 94$ & KEH \\
\hline 94-600-039 & B Pond Interim Stabilization & III & $5 / 5 / 94$ & $5 / 16 / 94$ & WHC \\
\hline $94-600-040$ & $\begin{array}{l}\text { W-058 Replacement of Cross-Site } \\
\text { Transfer Line \#2 }\end{array}$ & V & $4 / 1 / 94$ & $7 / 21 / 94$ & WHC \\
\hline $94-600-041$ & $\begin{array}{l}\text { W.S.C.F. Transformer Removal \& } \\
\text { Electrical Vault }\end{array}$ & 1 & $5 / 9 / 94$ & $5 / 13 / 94$ & KEH \\
\hline $94-600-042$ & Service to 506BA Bldg & III & $5 / 10 / 94$ & $5 / 18 / 94$ & KEH \\
\hline $94-600-043$ & $\begin{array}{l}\text { Gravel Pit \#9 for Inert/Demolition Waste } \\
\text { Landfill }\end{array}$ & III & $5 / 16 / 94$ & $6 / 15 / 94$ & KEH \\
\hline $94-600-044$ & 200-BP-5, 600 Area Well Drilling & $\mathrm{IIN}$ & $5 / 16 / 94$ & $5 / 24 / 94$ & WHC \\
\hline $94-600-045$ & McGee Ranch Mitigation Plan & $\mathrm{V}$ & $5 / 16 / 94$ & & WHC \\
\hline $94-600-046$ & $\begin{array}{l}\text { Replace Lead Acid Battery Cells at RRHW } \\
\text { Crossing \#2 \& \#9 }\end{array}$ & 1 & $5 / 17 / 94$ & $5 / 20 / 94$ & KEH \\
\hline $94-600-047$ & $\begin{array}{l}\text { TCl Cablevision - Joint Use with City of } \\
\text { Richland }\end{array}$ & $\mathrm{n} / \mathrm{a}$ & $5 / 20 / 94$ & & DOE \\
\hline $94-600-048$ & 7U-94-00013 - Laydown Yard & III & $6 / 3 / 94$ & $6 / 23 / 94$ & $\mathrm{KEH}$ \\
\hline $94-600-049$ & Disposition of the BC Controlled Area & V & $6 / 6 / 94$ & & WHC \\
\hline $94-600-050$ & Telephone Cable/MO-304 & III & $6 / 14 / 94$ & $6 / 16 / 94$ & WHC \\
\hline $94-600-051$ & Removal of Radio Telescope & $\mathrm{VI}$ & $6 / 21 / 94$ & $7 / 15 / 94$ & PNL \\
\hline $94-600-052$ & $\begin{array}{l}\text { Grout Waste Test Facility } \\
\text { Decommissioning }\end{array}$ & III & $6 / 23 / 94$ & $6 / 27 / 94$ & PNL \\
\hline $94-600-053$ & Hanford Infrastructure Fiber Loop & III & $6 / 23 / 94$ & $8 / 30 / 94$ & WHC \\
\hline $94-600-054$ & TWRS Complex - Sites A \& C & V/III & $5 / 11 / 94$ & & WHC \\
\hline $94-600-055$ & $\begin{array}{l}400 \text { Area Sanitary Sewer System } \\
\text { Replacement }\end{array}$ & $\mathrm{V}$ & $6 / 29 / 94$ & $7 / 27 / 94$ & KEH \\
\hline $94-600-056$ & 200-BP-5 Pump \& Treat & $\mathrm{V}$ & $7 / 8 / 94$ & & $\mathrm{BHI}$ \\
\hline 94-600-057 & Cold War Era ALE Cleanup & 1 & $7 / 11 / 94$ & $7 / 27 / 94$ & USACE \\
\hline $94-600-058$ & $\begin{array}{l}\text { Ground-Water Surveillance Project Soil } \\
\text { Gas Survey }\end{array}$ & IIII & $7 / 27 / 94$ & $8 / 19 / 94$ & PNL \\
\hline $94-600-059$ & HAMMER Training Center - Buried Cable & V/III & $8 / 3 / 94$ & $9 / 26 / 94$ & WHC \\
\hline $94-600-060$ & TWRS Complex Site B & V/III & $8 / 1 / 94$ & & WHC \\
\hline $94-600-061$ & Soil Sampling for HPADS & III & $8 / 23 / 94$ & $8 / 24 / 94$ & WHC \\
\hline $94-600-062$ & Cryocell Demonstration & III & $8 / 26 / 94$ & $9 / 12 / 94$ & PNL \\
\hline $94-600-063$ & $\begin{array}{l}\text { ER6037, Access Control Physical } \\
\text { Changes, Hanford Site Rd \& St Signs }\end{array}$ & III & $9 / 8 / 94$ & $9 / 13 / 94$ & KEH \\
\hline $94-600-064$ & Emergency Dispatch Center & $\mathrm{V} \mathrm{V} / \mathrm{I}$ & 9/9/94 & $9 / 20 / 94$ & $\mathrm{DOE}$ \\
\hline $94-600-065$ & W-058 Cross-Site Transfer Line \#3 & $I I I N$ & $9 / 16 / 94$ & $9 / 30 / 94$ & WHC \\
\hline $94-700-001$ & 720 Goethels, Richland & III & $3 / 14 / 94$ & $3 / 17 / 94$ & DOE \\
\hline $94-700-002$ & IRM Litigation Support Facility & III & $3 / 30 / 94$ & $3 / 31 / 94$ & KEH \\
\hline 94-700-003 & 712 Bldg-Modify Electrical Ground & III & $5 / 5 / 94$ & $5 / 10 / 94$ & KEH \\
\hline
\end{tabular}




\begin{tabular}{|c|c|c|c|c|c|}
\hline $\begin{array}{c}\text { Case } \\
\text { Number } \\
\end{array}$ & Project Name & Clasi & $\begin{array}{c}\text { Date } \\
\text { Received }\end{array}$ & $\begin{array}{c}\text { Date } \\
\text { Completed } \\
\end{array}$ & $\begin{array}{l}\text { Requesting } \\
\text { Organization } \\
\end{array}$ \\
\hline $94-700-004$ & Bldg 703 Lawn Sprinkler Line Repair & 1 & $5 / 13 / 94$ & $5 / 16 / 94$ & KEH \\
\hline $94-700-005$ & $\begin{array}{l}\text { GTE Property Transfer at } 751 \text { Mansfield } \\
\text { St }\end{array}$ & $n / a$ & $5 / 19 / 94$ & $6 / 20 / 94$ & DOE \\
\hline 94-700-006 & Repair Lawn Sprinkler Piping at Bldg 712 & 1 & $8 / 10 / 94$ & $8 / 12 / 94$ & $\mathrm{KEH}$ \\
\hline 94-700-007 & 712 Bldg Energy Use Reduction & Vl/III & $9 / 28 / 94$ & $9 / 29 / 94$ & KEH \\
\hline $\begin{array}{l}94-1100- \\
001\end{array}$ & $\begin{array}{l}\text { Road, Ground, Lighting Improve, } \\
1100 / 300 \text { Area }\end{array}$ & 1 & $11 / 2 / 93$ & $11 / 3 / 93$ & KEH \\
\hline $\begin{array}{l}94-1100- \\
002\end{array}$ & $\begin{array}{l}\text { Explosion Panel Replacement, Bldg } \\
1162\end{array}$ & VI & $11 / 2 / 93$ & $11 / 5 / 93$ & WHC \\
\hline $\begin{array}{l}94-1100- \\
003\end{array}$ & Fiber Cable in 1100 Area and N. Richland & III & $2 / 9 / 94$ & $2 / 10 / 94$ & WHC \\
\hline $\begin{array}{l}94-1100- \\
004\end{array}$ & $\begin{array}{l}3 \mathrm{U}-91-02334, \mathrm{MO}-404 \text { Backdoor } \\
\text { Platform }\end{array}$ & III & $3 / 8 / 94$ & $3 / 16 / 94$ & KEH \\
\hline $\begin{array}{l}94-1100- \\
005\end{array}$ & 16-Wide MO Complex in 1100 Area & III & $4 / 19 / 94$ & $4 / 22 / 94$ & $\mathrm{KEH}$ \\
\hline $\begin{array}{l}94-1100- \\
006\end{array}$ & U-22 Fire Hydrant Repair & $\mathrm{I}$ & $6 / 6 / 94$ & $6 / 9 / 94$ & KEH \\
\hline $\begin{array}{l}94-1100- \\
007\end{array}$ & Bldg 1171 Lunchroom Upgrade & VI & $6 / 8 / 94$ & $6 / 13 / 94$ & KEH \\
\hline $\begin{array}{l}94-1100- \\
008\end{array}$ & Fiber Tie Cable IVDTS to $1163 \mathrm{Bldg}$ & III & $6 / 6 / 94$ & $6 / 14 / 94$ & KEH \\
\hline $\begin{array}{l}94-1100- \\
009 \\
\end{array}$ & 1171 Restore Power to Yard Light & III & $6 / 20 / 94$ & $6 / 24 / 94$ & KEH \\
\hline $\begin{array}{l}94-1100- \\
010\end{array}$ & $\begin{array}{l}\text { Blade, Grade, Gravel, \& Compact } 1163 \\
\text { Bldg N. Park }\end{array}$ & $\mathrm{I}$ & $7 / 6 / 94$ & $7 / 13 / 94$ & KEH \\
\hline $\begin{array}{l}94-1100- \\
011\end{array}$ & $\begin{array}{l}\text { Improve UPS Line at } 1163 \text { \& Remove } \\
1163 \text { Warehouse Free-Stand. Rm } \\
\text { Removal }\end{array}$ & $\overline{\mathrm{VI}}$ & $7 / 6 / 94$ & $7 / 20 / 94$ & KEH \\
\hline $\begin{array}{l}94-1100- \\
012 \\
\end{array}$ & $\begin{array}{l}\text { Lighting Replacement, } 1171 \text { Bldg Paint } \\
\text { Booth }\end{array}$ & $\overline{V I}$ & $9 / 2 / 94$ & $9 / 9 / 94$ & KEH \\
\hline $\begin{array}{l}94-3000- \\
001\end{array}$ & 3000 Area Building Demolitions. & VI & $3 / 8 / 94$ & & KEH \\
\hline \begin{tabular}{|l|}
$94-3000-$ \\
002 \\
\end{tabular} & EMSL North Field Site (Site 6) & III & $4 / 22 / 94$ & & PNL \\
\hline \begin{tabular}{|l|}
$94-3000-$ \\
003
\end{tabular} & City of RL-EMSL Permanent Easement & $\mathrm{V}$ & $6 / 29 / 94$ & $7 / 17 / 94$ & $\overline{\mathrm{DOE}}$ \\
\hline $\begin{array}{l}94-3000- \\
004\end{array}$ & $\begin{array}{l}\text { High Resolution Imaging of Deep Buried } \\
\text { Waste at IN }\end{array}$ & III & $6 / 29 / 94$ & $8 / 3 / 94$ & $\overline{P N L}$ \\
\hline
\end{tabular}


Appendix B 

Appendix B. Surveys Completed in FY 1994 for Section 106 Reviews

\begin{tabular}{|c|c|c|c|c|}
\hline $\begin{array}{c}\text { Case } \\
\text { Number } \\
\end{array}$ & Project Name & $\begin{array}{c}\begin{array}{c}\text { Area } \\
(\mathrm{km} 2)\end{array} \\
\end{array}$ & $\begin{array}{l}\text { Sites Recorded } \\
\text { During Survey }\end{array}$ & $\begin{array}{c}\text { Isolates Recorded } \\
\text { During Survey }\end{array}$ \\
\hline $93-300-063$ & $\begin{array}{l}\text { Project L-186, Hanford Site Entry } \\
\text { Control Center }\end{array}$ & 0.12 & $\begin{array}{l}\text { HT-94-001, HT-94-002, } \\
\text { HT-94-003. }\end{array}$ & none \\
\hline $94-100-007$ & 128-H-1 Burn Pit Soil-Gas Survey & 0.58 & none & none \\
\hline $94-100-024$ & $\begin{array}{l}\text { E-027, Reconfig. } 230 \mathrm{kv} \text { Trans. } \\
\text { Syst. }\end{array}$ & 0.58 & $\begin{array}{l}\text { HT-94-012, HT-94-013, } \\
\text { HT-94-014, HT-94-016 }\end{array}$ & HI-94-009, HI-94-010 \\
\hline 94-100-046 & N Springs Area Projects & 0.03 & HT-95-001, HT-95-007 & \\
\hline $94-200-097$ & $\begin{array}{l}\text { W-236A Multi-Function Waste } \\
\text { Tank Facility - 200E }\end{array}$ & 0.17 & none & none \\
\hline 94-200-118 & Rt. 4 Improvement Projects & 0.006 & none & Inone \\
\hline $94-200-209$ & $\begin{array}{l}\text { B-604 Water System Upgrade - } \\
\text { Reservoir }\end{array}$ & 0.16 & none & none \\
\hline $94-300-008$ & 300 Area South Office Building & 0.32 & $\begin{array}{l}\text { HT-94-004, HT-94-017, } \\
\text { HT-94-018 }\end{array}$ & HI-94-015. \\
\hline $94-600-001$ & $\begin{array}{l}\text { Spent Nuclear Fuel Storage } \\
\text { Facility }\end{array}$ & 0.63 & none & $\mathrm{HI}-94-003$ \\
\hline $94-600-003$ & Basalt Quarry Sites & 3.24 & $\begin{array}{l}\text { HT-94-009, 010, 011, } \\
015,016,024,025, \\
\text { and } 026 .\end{array}$ & $\begin{array}{l}\mathrm{HI}-94-004,005,006, \\
007,008,012,013, \\
020,021,022,023, \\
024,025,026,027 \\
028,029,030,031 \\
032,035,036,037 \\
038,039, \text { and } 040 .\end{array}$ \\
\hline $94-600-008$ & L-094, Fire Dept. Facilities & 0.02 & none & none \\
\hline $94-600-009$ & $\begin{array}{l}\text { Rattlesnake Mountain Tower - } \\
\text { Bentori County PUD }\end{array}$ & $<.01$ & none & none \\
\hline $94-600-015$ & ALE Area Cleanup Sites & 0.14 & $\begin{array}{l}\text { HT-94-006, HT-94-007, } \\
\text { HT-94-008 }\end{array}$ & none \\
\hline $94-600-017$ & $\begin{array}{l}\text { Spent Nuclear Fuel Storage } \\
\text { Facility - Area } 2\end{array}$ & 0.78 & none. & HI-94-016, HI-94-017 \\
\hline $94-600-023$ & $\begin{array}{l}\text { Microbial Heterogeneity } \\
\text { Research } 1994\end{array}$ & 0.02 & HT-94-021 & none \\
\hline $94-600-032$ & $\begin{array}{l}\text { Topographic Survey for Area } \\
\text { South of } 200 \mathrm{~W}\end{array}$ & 0.03 & none & none \\
\hline $94-600-034$ & $\begin{array}{l}\text { ERDF - Project W-296 - NE } \\
\text { Portion }\end{array}$ & 1.13 & none & HI-94-018, HI-94-019 \\
\hline 94-600-035 & Subsurface Science Program & & none & none \\
\hline $94-600-040$ & $\begin{array}{l}\text { W-058 Replacement of Cross- } \\
\text { Site Transfer Line \#2 }\end{array}$ & 0.14 & HT-94-022 & none \\
\hline $94-600-044$ & 200-BP-5, 600 Area Well Drilling & 0.04 & none & none \\
\hline $94-600-045$ & McGee Ranch Mitigation Plan & & $\begin{array}{l}\text { HT-94-049, 050, 051, } \\
\text { 052, 055, 056, 057, } \\
\text { HP-94-001 }\end{array}$ & HI-94-047 \\
\hline 94-600-054 & TWRS Complex - Sites A \& C & 1.42 & none & HI-94-045, HI-94-046 \\
\hline $94-600-055$ & $\begin{array}{l}400 \text { Area Sanitary Sewer System } \\
\text { Replacement }\end{array}$ & 0.11 & none & none \\
\hline $94-600-056$ & 200-BP-5 Pump \& Treat & 0.03 & none & HI-94-033, HI-94-034 \\
\hline
\end{tabular}




\begin{tabular}{|c|c|c|c|c|}
\hline $\begin{array}{c}\text { Case } \\
\text { Number }\end{array}$ & Project Name & $\begin{array}{c}\text { Area } \\
(\mathrm{km} 2)\end{array}$ & $\begin{array}{l}\text { Sites Recorded } \\
\text { During Survey }\end{array}$ & $\begin{array}{c}\text { Isolates Recorded } \\
\text { During Survey }\end{array}$ \\
\hline $94-600-058$ & $\begin{array}{l}\text { Ground-Water Surveillance } \\
\text { Project Soil Gas Survey }\end{array}$ & 0.09 & HT-94-054 & none \\
\hline $94-600-059$ & $\begin{array}{l}\text { HAMMER Training Center - } \\
\text { Buried Cable }\end{array}$ & 0.02 & none & none \\
\hline $94-600-060$ & TWRS Complex Site B & 1.3 & none & none \\
\hline $94-600-065$ & $\begin{array}{l}\text { W-058 Cross-Site Transfer Line } \\
\# 3\end{array}$ & 0.04 & none & none \\
\hline $\begin{array}{l}94-3000- \\
002\end{array}$ & EMSL North Field Site (Site \#6) & 0.26 & $\begin{array}{l}\text { debris from Camp } \\
\text { Hanford, horse bone } \\
\text { fragments, remnants of } \\
\text { irrigation canal }\end{array}$ & \\
\hline $\begin{array}{c}94-3000- \\
003\end{array}$ & $\begin{array}{l}\text { City of RL-EMSL Permanent } \\
\text { Easement }\end{array}$ & 0.001 & none & none \\
\hline
\end{tabular}


Appendix C 

Appendix C. Buildings Documented in FY 1994 for Section 106 Reviews (Class VI)

\begin{tabular}{|c|c|c|c|}
\hline $\begin{array}{l}\text { Case } \\
\text { Number }\end{array}$ & Project Name & $\begin{array}{l}\text { No. of } \\
\text { Bldgs. }\end{array}$ & $\begin{array}{c}\text { Building Documentation } \\
\text { Sent to DOE-RL in FY } 1994\end{array}$ \\
\hline $93-100-023$ & Building 1702-DR Demolition & 1 & 1702-DR \\
\hline 93-100-041 & Demolition of Building Complex & 6 & $\begin{array}{l}\text { 185-D,189-D,190-D,190-DA, } \\
\text { 195-D, 1724-DA }\end{array}$ \\
\hline $93-100-042$ & Demolition of Building 1101-N & 1 & $1101-\mathrm{N}$ \\
\hline $93-100-044$ & Demolition of Building $1100-\mathrm{N}$ & 1 & $1100-N$ \\
\hline $93-100-071$ & 1102-N Building Demolition & 1 & $1102-\mathrm{N}$ \\
\hline $93-200-009$ & Demolition of Bldgs. 2701-EC, -EF -WC & 3 & 2701-EC, 2701-EF, 2701-WC \\
\hline 93-200-077 & Demolition of Bldgs. 2711-S \& 2718-S & 2 & $2711-S$ and $2718-S$ \\
\hline $93-200-143$ & Demo. of W-19 \& Siting of a Construct. Shop & 1 & W-19 (200W Area) \\
\hline $93-200-151$ & 233-S Facility Decommissioning & 1 & 233-S \\
\hline $93-200-152$ & 232-Z Waste Incinerator Facil. Decomm & 1 & $232-Z$ \\
\hline $93-300-009$ & Demolition of Building 3701-A & 1 & $3701-A$ \\
\hline $93-600-009$ & 604-F, 604-G \& 604-H Demolitions & 3 & $604-\mathrm{F}, 604-\mathrm{G}, 604-\mathrm{H}$ \\
\hline $94-100-038$ & 1713-H Warehouse Demolition & 1 & $1713-\mathrm{H}$ \\
\hline $94-100-055$ & N-Deactivation Small Bldgs Demolition & 7 & $\begin{array}{l}\text { 104-N,105-NC,109-NA, 109-NB, } \\
1112-N B, 1707-N, 1734-\mathrm{N}\end{array}$ \\
\hline 94-200-002 & 2724-W, -WA, and -WB Bldg Demos. & 3 & 2724-W, 2724-WA, 2724-WB \\
\hline $94-200-242$ & 2719-WA Demolition & 1 & 2719-WA \\
\hline $94-300-016$ & 313 Metal Fabrication Bldg. Lease & 1 & 313 \\
\hline $94-300-024$ & Badgehouse Demolitions & 10 & $\begin{array}{l}\text { 609, 2701-WA, 2701-WB, } \\
\text { Woodshack NW of 2701-WA, } \\
2701-E A,-E B,-E D, E E, 3701-L, \\
3701-N \text {. }\end{array}$ \\
\hline $94-300-042$ & Transition of 313 Bldg. to D \& D & 1 & 313 (Revised) \\
\hline $94-300-076$ & 3703 Demolition & 1 & 3703 \\
\hline $94-3000-001$ & 3000 Area Building Demolitions & 17 & $\begin{array}{l}1154,1208,1209,1211,1226, \\
1227,1235,1240,1241,1242, \\
1250,1252,1253,1256,1262, \\
1264,1301 .\end{array}$ \\
\hline
\end{tabular}



Appendix D

4 

Appendix D. Archaeological Sites Identified in FY 1994

\begin{tabular}{|c|c|c|c|c|}
\hline $\begin{array}{l}\text { HCRL Temp. } \\
\text { Site Number }\end{array}$ & $\begin{array}{c}\text { Permanent } \\
\text { Number }\end{array}$ & Site Type & Category & $\begin{array}{l}\text { Project } \\
\text { Number }\end{array}$ \\
\hline HT-94-001 & Not assigned & Historic Debris Scatter & Historic & $93-300-063$ \\
\hline HT-94-002 & Not assigned & Insulators & Historic & $93-300-063$ \\
\hline HT-94-003 & Not assigned & Historic Debris Scatter & Historic & $93-300-063$ \\
\hline HT-94-004 & Not assigned & Historic Debris Scatter & Historic & $94-300-008$ \\
\hline HT-94-005 & 3-121 & White Bluffs Road & Historic & None Assigned \\
\hline HT-94-006 & Not assigned & Cistern & Historic & 94-600-015 \\
\hline HT-94-007 & Not assigned & Cistern & Historic & 94-600-015 \\
\hline HT-94-008 & Not assigned & Building & Historic & $94-600-015$ \\
\hline HT-94-009 & Not assigned & \begin{tabular}{|l|} 
Lithic Scatter \\
\end{tabular} & Prehistoric & 94-600-003 \\
\hline HT-94-010 & Not assigned & Rock Feature & Undetermined & 94-600-003 \\
\hline HT-94-011 & Not assigned & Cairn & Undetermined & 94-600-003 \\
\hline HT-94-012 & Not assigned & Can Scatter & Historic & $94-100-024$ \\
\hline HT-94-013 & Not assigned & Historic Debris Scatter & Historic & 94-100-024 \\
\hline HT-94-014 & Not assigned & Historic Debris Scatter & Historic & $94-100-024$ \\
\hline HT-94-015 & Not assigned & Multicomponent & Both & $94-600-003$ \\
\hline HT-94-016 & Not assigned & Multicomponent & Both & 94-100-024 \\
\hline HT-94-017 & Not assigned & Cairn & Historic & 94-300-008 \\
\hline HT-94-018 & $3-21$ & Irrigation Canal & Historic & 94-300-008 \\
\hline HT-94-021 & Not assigned & Palmer Road & Historic & 94-600-023 \\
\hline HT-94-022 & Not assigned & Historic Debris Scatter & Historic & 94-600-040 \\
\hline HT-94-023 & Not assigned & Lithic Scatter. & Prehistoric & None Assigned \\
\hline HT-94-024 & Not assigned & Can Scatter & Historic & 94-600-003 \\
\hline HT-94-025 & Not assigned & Can Scatter & Historic & 94-600-003 \\
\hline HT-94-026 & Not assigned & Rock Features & Undetermined & $94-600-003$ \\
\hline HT-94-049 & Not assigned & Rock Cairn & Prehistoric & 94-600-045 \\
\hline HT-94-050 & Not assigned & Lithic Scatter & Prehistoric & 94-600-045 \\
\hline HT-94-051 & Not assigned & Rock Feature & Historic & 94-600-045 \\
\hline HT-94-052 & Not assigned & Debris Concentration & Historic & 94-600-045 \\
\hline HT-94-053 & Not assigned & Possible Hearth Feature & Prehistoric & 94-3000-002 \\
\hline HT-94-054 & Not assigned & Historic Debris Scatter & Historic & $94-600-058$ \\
\hline HT-94-055 & Not assigned & Homestead Site & Historic & $94-600-045$ \\
\hline HT-94-056 & Not assigned & McGee Farmstead & Historic & $94-600-045$ \\
\hline HT-94-057 & Not assigned & Irrigation System & Historic & 94-600-045 \\
\hline HT-94-058 & Not assigned & Habitation & Prehistoric & None Assigned \\
\hline HP-94-001 & Not assigned & Fossilized Mammal Bones & |Paleontological & 94-600-045 \\
\hline
\end{tabular}



Appendix E 

Appendix E. Archaeological Isolates Identified in FY 1994

\begin{tabular}{|c|c|c|}
\hline $\begin{array}{c}\text { HCRL Temp. } \\
\text { Number }\end{array}$ & Category & Project Number \\
\hline $\mathrm{HI}-94-001$ & Prehistoric & $93-300-011$ \\
\hline HI-94-002 & Prehistoric & $93-300-011$ \\
\hline $\mathrm{HI}-94-003$ & Historic & $94-600-001$ \\
\hline $\mathrm{HI}-94-004$ & Prehistoric & 94-600-003 \\
\hline HI-94-005 & Prehistoric & 94-600-003 \\
\hline HI-94-006 & Prehistoric & $94-600-003$ \\
\hline $\mathrm{HI}-94-007$ & Prehistoric & $94-600-003$ \\
\hline $\mathrm{HI}-94-008$ & Prehistoric & 94-600-003 \\
\hline HI-94-009 & Historic & $94-100-024$ \\
\hline HI-94-010 & Historic & $94-100-024$ \\
\hline HI-94-012 & Prehistoric & $94-600-003$ \\
\hline $\mathrm{HI}-94-013$ & Prehistoric & 94-600-003 \\
\hline $\mathrm{HI}-94-015$ & Prehistoric & 94-300-008 \\
\hline HI-94-016 & Historic & $94-600-017$ \\
\hline $\mathrm{HI}-94-017$ & Historic & 94-600-017 \\
\hline HI-94-018 & Historic & $94-600-034$ \\
\hline HI-94-019 & Historic & $94-600-034$ \\
\hline HI-94-020 & Undetermined & 94-600-003 \\
\hline HI-94-021 & Historic & 94-600-003 \\
\hline $\mathrm{HI}-94-022$ & Historic : & 94-600-003 \\
\hline $\mathrm{HI}-94-023$ & Historic & 94-600-003 \\
\hline HI-94-024 & Historic & 94-600-003 \\
\hline $\mathrm{HI}-94-025$ & Prehistoric & 94-600-003 \\
\hline HI-94-026 & Prehistoric & 94-600-003 \\
\hline $\mathrm{HI}-94-027$ & Prehistoric & $94-600-003$ \\
\hline $\mathrm{HI}-94-028$ & Historic & $94-600-003$ \\
\hline HI-94-029 & Undetermined & $94-600-003$ \\
\hline $\mathrm{HI}-94-030$ & Historic & $94-600-003$ \\
\hline $\mathrm{HI}-94-031$ & Historic & $94-600-003$ \\
\hline $\mathrm{HI}-94-032$ & Prehistoric & $94-600-003$ \\
\hline $\mathrm{HI}-94-033$ & Historic & 94-600-056 \\
\hline $\mathrm{HI}-94-034$ & Historic & $94-600-056$ \\
\hline HI-94-035 & Undetermined & $94-600-003$ \\
\hline HI-94-036 & Historic & 94-600-003 \\
\hline $\mathrm{HI}-94-037$ & Historic & $94-600-003$ \\
\hline $\mathrm{HI}-94-038$ & Undetermined & $94-600-003$ \\
\hline $\mathrm{HI}-94-039$ & Undetermined & 94-600-003 \\
\hline $\mathrm{HI}-94-040$ & Historic & $94-600-003$ \\
\hline $\mathrm{HI}-94-045$ & Prehistoric & $94-600-054$ \\
\hline HI-94-046 & Prehistoric & $94-600-054$ \\
\hline $\mathrm{HI}-94-047$ & Prehistoric & $94-600-045$ \\
\hline
\end{tabular}





\section{Distribution}

No. Of

Copies

State Historic Preservation Officer

Olffice of Archaeology \& Historic

Preservation

11 West 21st Ave., KL-11

Olympia, WA 98504-5411

The Confederated Tribes of

the Umatilla Indian Reservation

J. Van Pelt

P.O. Box 638

Pendleton, OR 97810

The Wanapum Indian Tribe

L. Seelatsee

P.O. Box 878

Ephrata, WA 98823

The Yakama Indian Nation

Office of Legal Counsel

R. Snowarrow Flint Knife

P.O. Box 151

Toppenish, WA 98948

The Yakama Indian Nation

Environmental Restoration and Waste

Management

R. Jim

P. O. Box 151

Toppenish, WA 98948

Nez Perce Tribe Environmental

Restoration and Waste

Management

Attn: J. Fitch

P.O. Box 365

Lapwai, ID 83540
No. Of

Copies

ON SITE

2 DOE/Office of Scientific and Technical Information

5 DOE Richland Operations Office J. B. Hall A5-55

D. W. Lloyd

A5-15

D. C. Ward

A5-55

DOE Legal Library

A4-78

Public Reading Room

A1-65

21 Pacific Northwest National Laboratory

P. R. Nickens (20)

K6-75

Publishing Coordination

Bechtel Hanford, Inc.

T. E. Marceau

H6-02

$\mathrm{CH}_{2} \mathrm{M}$ Hill Hanford

D. C. Stapp

H9-03

2 Westinghouse Hanford Company

M. S. Gerber

C. L. Nansen

N1-40

R3-61 
